Supporting Information for

\title{
A Bioinspired Disulfide/Dithiol Redox Switch in a Rhenium Complex as Proton, H Atom, and Hydride Transfer Reagent
}

\author{
Shao-An Hua ${ }^{\dagger}$, Lucas A. Paul ${ }^{\dagger}$, Manuel Oelschlegel ${ }^{\dagger}$, Sebastian Dechert ${ }^{\dagger}$, \\ Franc Meyer $^{\dagger, \S, *}$ and Inke Siewert ${ }^{\dagger, \S, *}$
}

$\dagger$ Universität Göttingen, Institut für Anorganische Chemie, Tammannstraße 4, D-37077

Göttingen, Germany

$\S$ Universität Göttingen, International Center for Advanced Studies of Energy Conversion (ICASEC), Tammannstraße 6, D-37077 Göttingen, Germany

Corresponding Authors:

E-Mail: franc.meyer@chemie.uni-goettingen.de

E-Mail: inke.siewert@chemie.uni-goettingen.de 


\section{Table of Content}

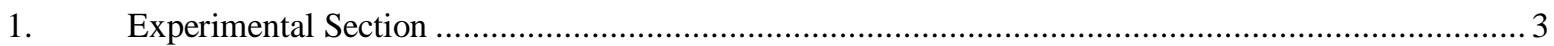

1.1. General Consideration and Materials ................................................................................ 3

1.2. Nuclear Magnetic Resonance Spectroscopy …......................................................... 3

1.3. Electrochemical Measurements and Digital Simulation of CV Data...................................... 3

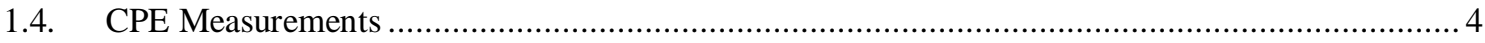

1.5. Quantification of the $\mathrm{CO}_{2}$ Reduction Products after Coulometry......................................... 4

1.6. UV-vis Spectroscopy and Spectroelectrochemistry .................................................. 4

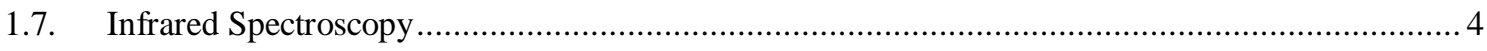

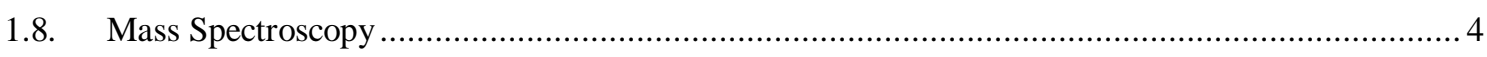

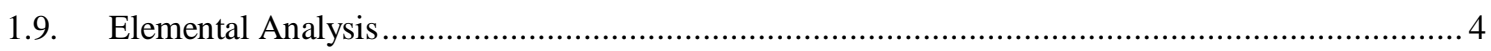

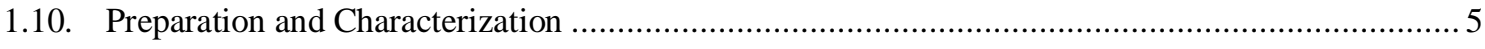

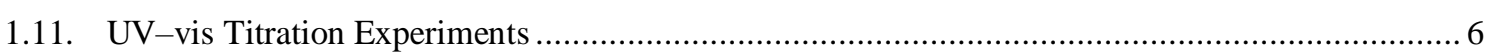

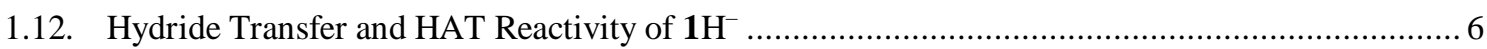

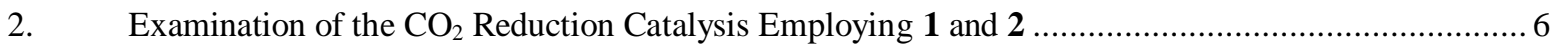

2.1. Determination of the Overpotential and Reaction Rate of the $\mathrm{CO}_{2}$ Reduction Catalysis ...............8 8

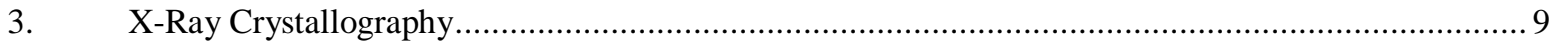

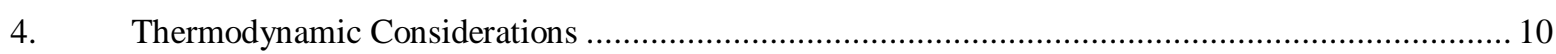

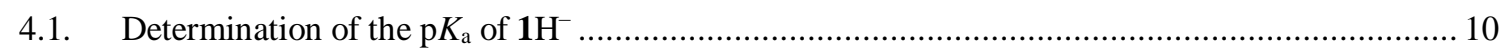

4.2. Temperature Dependence of the Equilibrium Constant .................................................. 12

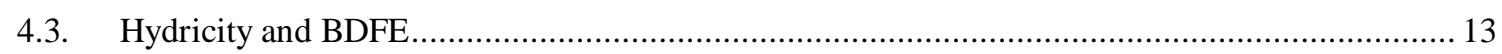

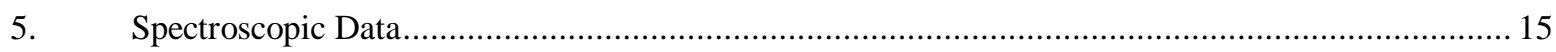

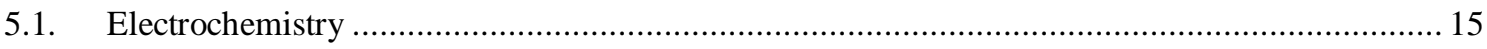

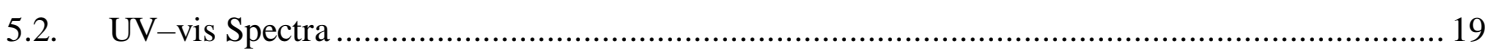

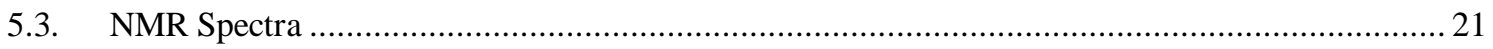

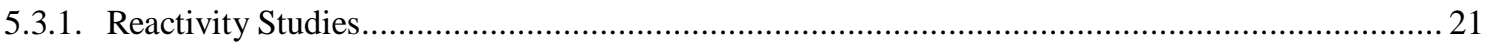

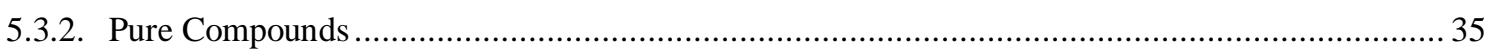

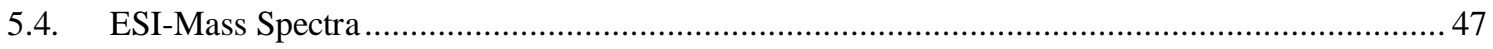

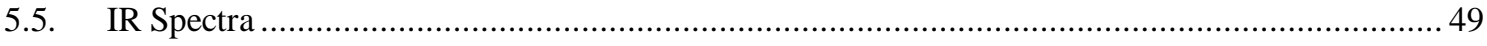

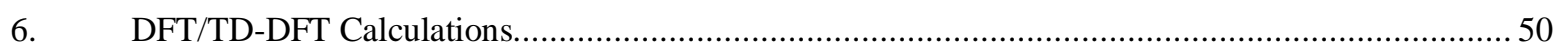

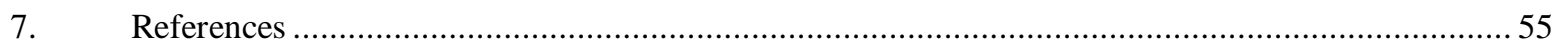




\section{Experimental Section}

\subsection{General Consideration and Materials}

If not otherwise stated, all manipulations of air-sensitive reagents were carried out by means of common Schlenk-type techniques involving the use of a dry argon or nitrogen atmosphere or performed in a $\mathrm{N}_{2}-$ filled MBraun glovebox. $\mathrm{MeCN}$ was dried over $\mathrm{CaH}_{2}$, distilled and stored over molecular sieves $3 \AA$ prior to use. Trifluoroethanol (TFE) was dried over $3 \AA$ molecular sieves. Deuterated solvents were obtained from Deutero $\mathrm{GmbH}$, dried over molecular sieves $(3 \AA)$ and degassed. [ $\left.{ }^{\mathrm{n}} \mathrm{Bu}_{4} \mathrm{~N}\right] \mathrm{PF}_{6}$ was dried in vacuo at $80{ }^{\circ} \mathrm{C}$ for $2 \mathrm{~d}$, then transferred to the $\mathrm{N}_{2}$-filled MBraun glovebox prior to use. $\left[\mathrm{HNEt}_{3}\right] \mathrm{PF}_{6},{ }^{1}$ [BIM] $\mathrm{PF}_{6},{ }^{2 \mathrm{~S}-\mathrm{S}}$ bpy and ${ }^{\mathrm{S}} \mathrm{bpy}^{3}$ were prepared according to the literature procedures. All used chemicals were reagent grade or higher. Silica gel $60 \AA$ with $40-63 \mu \mathrm{m}$ was used for chromatography.

\subsection{Nuclear Magnetic Resonance Spectroscopy}

The ${ }^{1} \mathrm{H}$ - and ${ }^{13} \mathrm{C}\left\{{ }^{1} \mathrm{H}\right\}$-NMR spectra were recorded with a Bruker Avance III $400 \mathrm{NMR}\left({ }^{1} \mathrm{H} 400 \mathrm{MHz}\right)$ or a Bruker Avance III HD $500 \mathrm{NMR}$ spectrometer $\left({ }^{1} \mathrm{H} 500 \mathrm{MHz},{ }^{13} \mathrm{C} 125 \mathrm{MHz}\right)$ with $\mathrm{CDCl}_{3}-d_{3}$ and $\mathrm{MeCN}-d_{3}$ as the solvents at $25{ }^{\circ} \mathrm{C}$ or $-30{ }^{\circ} \mathrm{C}$. The ${ }^{1} \mathrm{H}$ and ${ }^{13} \mathrm{C}\left\{{ }^{1} \mathrm{H}\right\}$ NMR spectra were calibrated against the residual ${ }^{1} \mathrm{H}$ and natural-abundance ${ }^{13} \mathrm{C}$ resonances of the deuterated solvents $\left(\mathrm{CDCl}_{3} \delta_{\mathrm{H}}=7.26 \mathrm{ppm}\right.$; $\left.\mathrm{MeCN}-d_{3} \delta_{\mathrm{H}}=1.94 \mathrm{ppm}\right)$.

\subsection{Electrochemical Measurements and Digital Simulation of CV Data}

Electrochemical measurements were recorded under inert atmospheres via Schlenk line techniques or in a MBraun glovebox, with Gamry Instruments Ref $600+, 1010 \mathrm{~B}$ or 1010E in dry MeCN. MeCN and TFE were purchased from Sigma-Aldrich and dried and stored over molecular sieve ( $3 \AA$ ) prior to use. A common three electrode setup was used with a glassy carbon working electrode (GC: CH Instruments or ALS Japan; $A=7.1 \mathrm{~mm}^{2}$ ), a platinum wire as a counter electrode, and a silver wire in silver nitrate solution $(I=0.01 \mathrm{M})$ as pseudo reference electrode. $\left[{ }^{n} \mathrm{Bu}_{4} \mathrm{~N}\right] \mathrm{PF}_{6}$ was used as conducting salt, $I=0.1$ or $0.2 \mathrm{M}$ for the measurements performed at 298 and $238 \mathrm{~K}$, respectively, and reactant concentrations were about $1 \mathrm{mM}$. All data were referenced internally $v s$. the $\mathrm{Fc}^{+/ 0}$ redox potential at the respective temperature. $\mathrm{i} R$ compensation was performed by the positive feedback method, which is implemented in the PHE200 software of Gamry.

In order to account for the shift of ferrocene's redox potential with the temperature, we applied the method described previously in detail. ${ }^{4}$ In short, the formal potential of $\mathrm{Fc}^{+10}$ at $238 \mathrm{~K}$ has been corrected for the temperature shift of ferrocene's redox potentials with regard to rt in acetonitrile (Table S1). ${ }^{5}$ The redox potentials at $238 \mathrm{~K}$ has been estimated from the linearization of the data points from Ref 5 . The difference in $\mathrm{mV}$ between the potential at $\mathrm{rt}$ and $238 \mathrm{~K}$ has been subtracted (Table S2).

For digital simulation, the values for the redox potentials were set with an accuracy of $5 \mathrm{mV}$. The diffusion coefficients of $\mathbf{1}$ at temperatures of $238 \mathrm{~K}$ and $298 \mathrm{~K}$ have been determined by ${ }^{1} \mathrm{H}$ DOSYNMR spectroscopy in $\mathrm{MeCN}-d_{3}$.

Table S1. Redox potentials offerrocene vs. Ag/AgCl in $\mathrm{MeCN}, 2 \mathrm{mMFc}, v=0.1 \mathrm{Vs}^{-1}, 0.1 \mathrm{M}\left[{ }^{n} \mathrm{Bu}_{4} \mathrm{~N}\right] P F_{6}{ }^{5}$

\begin{tabular}{ll}
\hline $\mathrm{T} / \mathrm{K}$ & $E^{\mathrm{Fc}} / \mathrm{V}$ \\
\hline 248.15 & 0.973 \\
273.15 & 0.986 \\
298.15 & 0.995 \\
\hline
\end{tabular}

Table S2. Calculated redox potential of ferrocene $\left(E^{F c, \text { calc }}\right)$ and difference $\left(\Delta E^{F c}{ }_{238 K}\right)$ of the potential between $r t\left(E^{F c_{298 K}}\right)$ and $238 \mathrm{~K}\left(E^{F c_{238 K}}\right)$ in MeCN with [ $\left.{ }^{n} B u_{4} N\right] P F_{6}$ as electrolyte.

\begin{tabular}{lll}
\hline $\mathrm{T} / \mathrm{K}$ & $E^{\mathrm{Fc}, \text { calc }} / \mathrm{V}$ & $\left(\Delta E^{\mathrm{Fc}}\right) / \mathrm{V}$ \\
\hline 238 & 0.969 & 0.026 \\
\hline
\end{tabular}




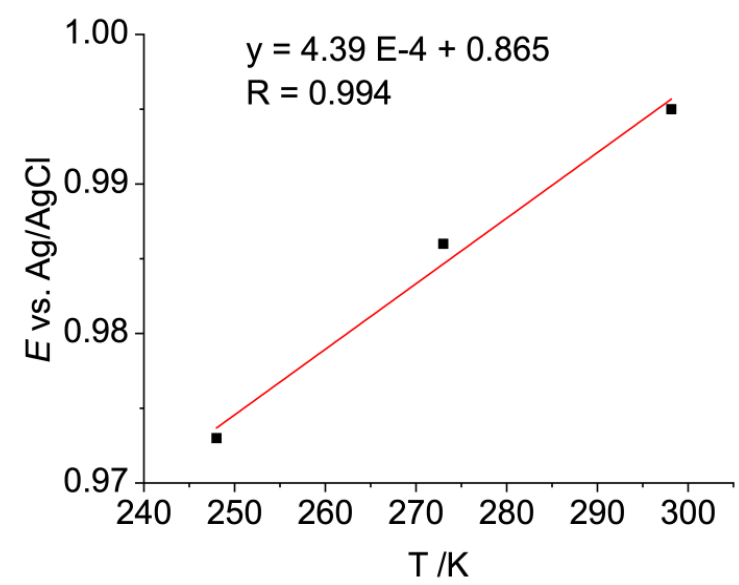

Figure S1. Plot of the potential of ferrocene's redox couple vs. $\mathrm{Ag} / \mathrm{AgCl}$ in $\mathrm{MeCN}$ at various temperatures, $2 \mathrm{mM} \mathrm{Fc}, v=0.1 \mathrm{Vs}^{-1}, 0.1 \mathrm{M}\left[{ }^{n} B u_{4} N\right] P F_{6}{ }^{5}$ The red line represents the fit.

\subsection{CPE Measurements}

In the CPE experiments, the counter electrode was separated from the bulk solution by a sample holder with a porous glass frit. A $3 \mathrm{~mm}$ glassy carbon rod was used as working electrode, and a Pt spiral electrode as counter electrode.

\subsection{Quantification of the $\mathrm{CO}_{2}$ Reduction Products after Coulometry}

$\mathrm{CO}$ and $\mathrm{H}_{2}$ were detected and quantified with a Shimadzu GC-2014 equipped with a thermal conductivity detector (TCD) and a ShinCarbon ST 80/100 silco column. Methane was used as an internal standard in order to determine $n_{\mathrm{H} 2}$ and $n_{\mathrm{CO}}$. FE were calculated according to $n$ (measured $)_{\mathrm{H} 2 / \mathrm{CO}} /(Q / 2 F)$, $Q=$ electric charge. Calibration curves for $\mathrm{CH}_{4} / \mathrm{H}_{2}$ and $\mathrm{CH}_{4} / \mathrm{CO}$ were determined separately by injecting known quantities of the mixtures. ${ }^{13} \mathrm{C}$-Formate (and ${ }^{13} \mathrm{CO}$ ) were analyzed by ${ }^{13} \mathrm{C}$ NMR spectroscopy using the Bruker Avance III HD 500 NMR spectrometer $\left({ }^{13} \mathrm{C} 125.8 \mathrm{MHz}\right)$ equipped with a cryo probe.

\subsection{UV-vis Spectroscopy and Spectroelectrochemistry}

UV-vis spectra were recorded with an Agilent Cary 60 spectrometer equipped with an Unisoku CoolSpek temperature control unit. (Spectro)electrochemistry experiments were performed in a $\mathrm{N}_{2-}$ filled glovebox with an Interface 1010B potentiostat, Deuterium/Tungsten light source (BWTEK), Exemplar LS spectrometer (BWTEK), and quartz cuvettes. A platinum mesh was used as working electrode, a platinum wire was used as the auxiliary electrode, and an Ag wire was used as pseudo reference electrode. $0.2 \mathrm{M}\left[{ }^{\mathrm{n}} \mathrm{Bu}_{4} \mathrm{~N}\right] \mathrm{PF}_{6}$ in $\mathrm{MeCN}$ was used as supporting electrolyte.

\subsection{Infrared Spectroscopy}

The IR spectra were recorded with a Bruker Vertex 70 IR spectrometer.

\subsection{Mass Spectroscopy}

ESI-Mass spectra were recorded using a Bruker maXis mass spectrometer.

\subsection{Elemental Analysis}

Microanalyses were performed by the Analytical Service at the Department of Chemistry of the GeorgAugust University with an Elementar Vario El II elemental analyser. 
1.10. Preparation and Characterization

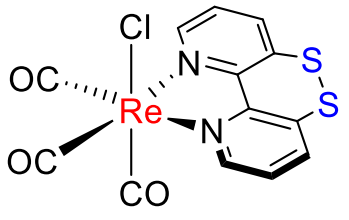

1

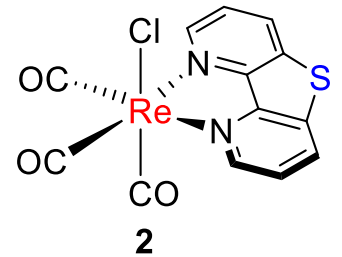

2

Figure S2. Two rhenium complexes which are subject of this study.

$\mathbf{1}$ and $\mathbf{2}$ have been synthesized previously in moderate yields and purity. ${ }^{6}$ We utilized a different synthesis and characterized the complexes by the usual methods.

$\operatorname{Re}\left({ }^{S-S}\right.$ bpy $)(C O)_{3} C l(1) .{ }^{S-S}$ bpy $\left(250 \mathrm{mg}, 1.15 \mathrm{mmol}, 1.00\right.$ equiv) and $\mathrm{Re}(\mathrm{CO})_{5} \mathrm{Cl}(414 \mathrm{mg}, 1.15 \mathrm{mmol}$, 1.00 equiv) were placed in a $50 \mathrm{~mL}$ round bottom Schlenk flask. Dried and degassed toluene $(25 \mathrm{~mL})$ were added, and the mixture was heated at $100{ }^{\circ} \mathrm{C}$ for $1 \mathrm{~h}$ under Ar. During the period, the solution color turned to orange. After cooling to rt, the mixture was concentrated to about $5 \mathrm{~mL}$ under reduced pressure, filtered, and the powder was washed with diethyl ether $(3 \times 10 \mathrm{~mL})$ and dried under reduced pressure (535 mg, 89\%). Deep red crystals suitable for X-ray diffraction were obtained by slow diffusion of diethyl ether into a $\mathrm{CH}_{2} \mathrm{Cl}_{2}$ solution of 1 . Anal. Calc. for $\mathrm{C}_{13} \mathrm{H}_{6} \mathrm{~N}_{2} \mathrm{ClO}_{3} \mathrm{ReS}_{2}$ : \% C 29.80, \% H 1.15, \% N 5.35, \% S 12.24. Found: \% C 29.96, \% H 1.10, \% N 5.31, \% S 11.75. IR (KBr pellet): $\tilde{v}\left[\mathrm{~cm}^{-1}\right]=3430$ (w), 3064 (vw), 2922 (vw), 2026 (vs, CO), 1900 (vs, CO), 1860 (s), 1558 (w), 1540 (w), 1408 (m), 1262 (w), $1215(\mathrm{w}), 820(\mathrm{~m}), 720(\mathrm{w}), 644(\mathrm{w}) .{ }^{1} \mathrm{H}$ NMR $\left(500 \mathrm{MHz}, \mathrm{CDCl}_{3}\right) \delta[\mathrm{ppm}]=8.92\left(1, \mathrm{dd}, 2 \mathrm{H}, J_{1-2}\right.$ $\left.=5.5 \mathrm{~Hz}, J_{1-3}=1.5 \mathrm{~Hz}\right), 7.91\left(3, \mathrm{dd}, 2 \mathrm{H}, J_{3-2}=8.0 \mathrm{~Hz}, J_{3-1}=1.0 \mathrm{~Hz}\right), 7.47\left(2, \mathrm{dd}, 2 \mathrm{H}, J_{2-3}=8.0 \mathrm{~Hz}, J_{2-1}\right.$ $=5.5 \mathrm{~Hz}) .{ }^{13} \mathrm{C}\left\{{ }^{1} \mathrm{H}\right\} \mathrm{NMR}\left(125 \mathrm{MHz}, \mathrm{CDCl}_{3}\right) \delta[\mathrm{ppm}]=153.97$ (5), 152.03 (1), 137.86 (3), 135.40 (4), 127.64 (2). $\mathrm{ESI}(+)-\mathrm{MS}\left(\mathrm{CH}_{2} \mathrm{Cl}_{2}, \mathrm{~m} / z\right.$, [rel int.] $)=546.90\left(100,[\mathrm{M}+\mathrm{Na}]^{+}\right), 488.9\left(40,\left[\mathrm{M}-\mathrm{Cl}^{+}\right)\right.$. $\mathrm{UV}-\mathrm{vis}\left(\mathrm{CH}_{3} \mathrm{CN}\right): \lambda_{\max }\left[\mathrm{nm}, \varepsilon\left(\mathrm{L} \cdot \mathrm{mol}^{-1} \cdot \mathrm{cm}^{-1}\right)\right]=285$ (20200), $314(8500), 415(4400)$.

$\operatorname{Re}\left({ }^{S}\right.$ bpy $)(\mathrm{CO})_{3} \mathrm{Cl}(2) .{ }^{\mathrm{S}} \mathrm{bpy}\left(100 \mathrm{mg}, 0.54 \mathrm{mmol}, 1.10\right.$ equiv) and $\operatorname{Re}(\mathrm{CO})_{5} \mathrm{Cl}(176 \mathrm{mg}, 0.49 \mathrm{mmol}, 1.00$ equiv) were placed in a $50 \mathrm{~mL}$ round bottom Schlenk flask. Dry and degassed toluene $(25 \mathrm{~mL})$ were added, and the mixture was heated at $100{ }^{\circ} \mathrm{C}$ for $4 \mathrm{~h}$. During the period, a yellow precipitate was formed. After cooling to $\mathrm{rt}$, the yellow powder was filtered, washed with diethyl ether $(3 \times 10 \mathrm{~mL})$ and dried under reduced pressure (168 mg, 70\%). Yellow crystals suitable for X-ray diffraction were obtained from a MeCN- $d_{3}$ solution of $\mathbf{1}^{2-}$ that was kept in a NMR tube for longer times. Anal. Calc. for $\mathrm{C}_{13} \mathrm{H}_{6} \mathrm{~N}_{2} \mathrm{ClO}_{3} \mathrm{ReS}: \% \mathrm{C} 31.74, \% \mathrm{H} 1.23, \% \mathrm{~N} 5.69, \% \mathrm{~S}$ 6.52. Found: \% C 31.51, \% H 1.23, \% N 5.68, \% S 6.71. IR (KBr pellet): $\tilde{v}\left[\mathrm{~cm}^{-1}\right]=3434$ (w), 3042 (vw), 2026 (vs, CO), 1922 (vs, CO), 1907 (vs, CO), 1568 (w), 1421 (m), 1405 (m), 1303 (w), 1224 (w), 1150 (w), 1060 (w), 808 (m), 740 (m), 721 $(\mathrm{m}), 648(\mathrm{~m}), 628(\mathrm{~m}) .{ }^{1} \mathrm{H}$ NMR $\left(500 \mathrm{MHz}, \mathrm{CDCl}_{3}\right) \delta[\mathrm{ppm}]=8.98\left(1, \mathrm{dd}, 2 \mathrm{H}, J_{1-2}=5.0 \mathrm{~Hz}, J_{1-3}=1.0\right.$ $\mathrm{Hz}), 8.45\left(3, \mathrm{dd}, 2 \mathrm{H}, J_{3-2}=8.5 \mathrm{~Hz}, J_{3-1}=1.0 \mathrm{~Hz}\right), 7.71\left(2, \mathrm{dd}, 2 \mathrm{H}, J_{2-3}=8.5 \mathrm{~Hz}, J_{2-1}=5.0 \mathrm{~Hz}\right) .{ }^{13} \mathrm{C}\left\{{ }^{1} \mathrm{H}\right\}$ $\mathrm{NMR}\left(125 \mathrm{MHz}, \mathrm{CDCl}_{3}\right) \delta[\mathrm{ppm}]=152.77$ (5), 149.51 (1), 133.61 (3), 133.46 (4), 125.58 (2). ESI(+)$\operatorname{MS}\left(\mathrm{CH}_{2} \mathrm{Cl}_{2}, \mathrm{~m} / \mathrm{z}\right.$, [rel int.] $)=516.90\left(100,[\mathrm{M}+\mathrm{Na}]^{+}\right), 456.97\left(60,[\mathrm{M}-\mathrm{Cl}]^{+}\right) . \mathrm{UV}-\mathrm{vis}\left(\mathrm{CH}_{3} \mathrm{CN}\right): \lambda_{\max }$

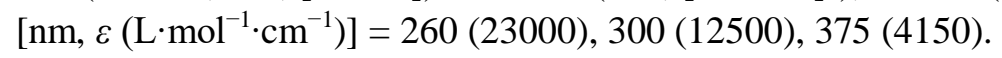

$\left[\operatorname{Re}\left({ }^{S 2} \mathrm{bpy}\right)(\mathrm{CO})_{3} \mathrm{Cl}\right]^{2-}\left(\mathbf{1}^{2-}\right)$. In the glovebox, $\mathbf{1}(5.0 \mathrm{mg}, 0.0095 \mathrm{mmol})$ were placed in an $8 \mathrm{~mL}$ vial and cooled to $-30{ }^{\circ} \mathrm{C}$ in the freezer. $\mathrm{CoCp}_{2}\left(3.7 \mathrm{mg}, 0.0196 \mathrm{mmol}, 2.05\right.$ equiv) were dissolved in $1 \mathrm{~mL}$ of $d_{3^{-}}$ $\mathrm{MeCN}$ at $-30^{\circ} \mathrm{C}$, and this solution was then transferred to the pre-cooled vial containing $\mathbf{1}$, followed by transferring into a pre-cooled J. Young NMR tube. The tube was transferred outside the glovebox and immediately immersed in liquid $\mathrm{N}_{2}$ until placed (thawed) into the spectrometer. All NMR data were recorded at $-30{ }^{\circ} \mathrm{C} .{ }^{1} \mathrm{H}$ NMR $\left(500 \mathrm{MHz}, \mathrm{MeCN}-d_{3}\right) \delta[\mathrm{ppm}]=8.09\left(1, \mathrm{dd}, 1 \mathrm{H}, J_{1-2}=5.0 \mathrm{~Hz}, J_{1-3}=1.5\right.$ $\mathrm{Hz}), 8.05\left(1^{\prime}, \mathrm{dd}, 1 \mathrm{H}, J_{1^{\prime}-2^{\prime}}=5.0 \mathrm{~Hz}, J_{1^{\prime}-3^{\prime}}=1.5 \mathrm{~Hz}\right), 7.60\left(3, \mathrm{dt}, 2 \mathrm{H}, J_{3-2}=8.0 \mathrm{~Hz}, J_{3-1}=1.5 \mathrm{~Hz}\right), 6.65$ $\left(2, \mathrm{dd}, 1 \mathrm{H}, J_{2-3}=8.0 \mathrm{~Hz}, J_{2-1}=5.0 \mathrm{~Hz}\right), 6.63\left(2^{\prime}, \mathrm{dd}, 1 \mathrm{H}, J_{2^{\prime}-3}=8.0 \mathrm{~Hz}, J_{2^{\prime}-1},=5.0 \mathrm{~Hz}\right){ }^{13} \mathrm{C}\left\{{ }^{1} \mathrm{H}\right\} \mathrm{NMR}$ $\left(125 \mathrm{MHz} \mathrm{MeCN}-d_{3}\right) \delta[\mathrm{ppm}]=200.64(\mathrm{CO}), 200.61(\mathrm{CO}), 193.79(\mathrm{CO}), 161.60(4), 160.06\left(5^{\prime}\right), 159.77$ (5'), 145.87 (3), 145.12 (3'), 139.82 (1), 139.57 (1'), 119.49 (2), 119.32 (2'). UV-vis (MeCN): $\lambda_{\max }[\mathrm{nm}$,

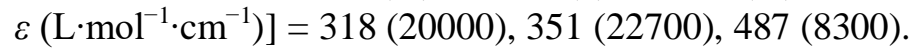


$\left[\mathrm{Re}\left({ }^{\mathrm{SHS}} \mathrm{bpy}\right)(\mathrm{CO})_{3} \mathrm{Cl}^{-}\left(\mathrm{IH}^{-}\right)\right.$. For the preparation of $\mathbf{1 H}^{-}$, a similar procedure as for $\mathbf{1}^{2-}$ was used. $\mathbf{1}(5.0$ $\mathrm{mg}, 0.0095 \mathrm{mmol})$ and $2.3 \mathrm{mg}$ of $\left[\mathrm{HNEt}_{3}\right] \mathrm{PF}_{6}(0.0097 \mathrm{mmol}, 1.02$ equiv) were placed in $8 \mathrm{~mL}$ vial prior to adding $3.6 \mathrm{mg}$ of $\mathrm{CoCp}_{2}\left(0.0190 \mathrm{mmol}, 2.0\right.$ equiv), which was dissolved in $1 \mathrm{~mL}$ of $\mathrm{MeCN}-d_{3}$ at -30 ${ }^{\circ} \mathrm{C}$. All NMR data were recorded at $-30{ }^{\circ} \mathrm{C} .{ }^{1} \mathrm{H}$ NMR $\left(500 \mathrm{MHz}, \mathrm{MeCN}-d_{3}\right) \delta[\mathrm{ppm}]=8.73(1, \mathrm{dd}, 2 \mathrm{H}$, $\left.J_{1-2}=5.5 \mathrm{~Hz}, J_{1-3}=1.5 \mathrm{~Hz}\right), 8.03\left(3, \mathrm{dd}, 2 \mathrm{H}, J_{3-2}=8.0 \mathrm{~Hz}, J_{3-1}=1.5 \mathrm{~Hz}\right), 7.28\left(2, \mathrm{dd}, 2 \mathrm{H}, J_{2-3}=8.0 \mathrm{~Hz}\right.$, $\left.J_{2-1}=5.0 \mathrm{~Hz}\right), 5.63(\mathrm{Cp}, \mathrm{s}, 8 \mathrm{H}), 2.54\left(\mathrm{CH}_{2}-\mathrm{NEt}_{3}, \mathrm{q}, 6 \mathrm{H},\right), 0.96\left(\mathrm{CH}_{3}-\mathrm{NEt}_{3}, \mathrm{t}, 9 \mathrm{H},{ }^{13} \mathrm{C}\left\{{ }^{1} \mathrm{H}\right\} \mathrm{NMR}(125\right.$ $\left.\mathrm{MHz} \mathrm{MeCN}-d_{3}\right) \delta[\mathrm{ppm}]=199.34(\mathrm{CO}), 192.12(\mathrm{CO}), 158.06$ (5), 147.82 (1), 147.26 (3), 123.67 (2), $85.52(\mathrm{Cp}), 46.35\left(\mathrm{CH}_{3} \mathrm{CH}_{2}\right), 11.06\left(\mathrm{CH}_{3} \mathrm{CH}_{2}\right) . \mathrm{UV}-\mathrm{vis}(\mathrm{MeCN}): \lambda_{\max }\left[\mathrm{nm}, \varepsilon\left(\mathrm{L} \cdot \mathrm{mol}^{-1} \cdot \mathrm{cm}^{-1}\right)\right]=291$ (19300), 320 (14300), 433 (6000).

\subsection{UV-vis Titration Experiments}

All UV-vis titration experiments were performed at $-30{ }^{\circ} \mathrm{C}$, and sample preparations were carried out in the $\mathrm{N}_{2}$-filled glovebox. For a typical experiment, $3 \mathrm{~mL} \mathrm{MeCN}$ solution of $1(0.05 \mathrm{mM})$ were placed in a $10 \mathrm{~mm}$ path quartz cuvette equipped with a stir bar and capped with a rubber septum. MeCN solutions of substrates were also prepared and transferred into a gas-tight syringe for later use. The cuvette was allowed to equilibrate temperature inside the cryostat for 10 minutes at $-30{ }^{\circ} \mathrm{C}$ and the spectrum of 1 was measured. For the redox titration, $0.9 \mathrm{mM}$ of $\mathrm{CoCp}_{2}$ solution was prepared and titrated into the solution of $\mathbf{1}$ in $10 \mu \mathrm{L}$ steps, and the spectral changes were recoded. For the acid titration, $\mathbf{1}^{2-}$ was generated in situ by adding 2.2 equiv of $\mathrm{CoCp}_{2}$ solution in $\mathrm{MeCN}(11 \mu \mathrm{L}, 30.0 \mathrm{mM})$ into the solution of 1. Then, $3.0 \mathrm{mM}$ of $\left[\mathrm{HNEt}_{3}\right] \mathrm{PF}_{6}$ solution was prepared and titrated into the solution of $\mathbf{1}^{2-}$ in $5 \mu \mathrm{L}$ steps, and the spectral changes were recorded. The same procedure was applied for the titration experiment using acetic acid. For the base titration, $1 \mathrm{H}^{-}$was generated in situ by adding 2.2 equiv of a CoCp 2 solution in $\mathrm{MeCN}(11 \mu \mathrm{L}, 30.0 \mathrm{mM})$ followed by 1.0 equiv of $\left[\mathrm{HNEt}_{3}\right] \mathrm{PF}_{6}$ solution $(10 \mu \mathrm{L}, 15.0$ $\mathrm{mM}$ ) into the solution of $\mathbf{1}$. Then, $3.0 \mathrm{mM}$ of ${ }^{\mathrm{t}} \mathrm{Bu}-\mathrm{P} 1$-(pyrr) $)_{3}$ solution was prepared and titrated into the solution of $1 \mathrm{H}^{-}$in $5 \mu \mathrm{L}$ steps, and the spectral changes were recoded.

\subsection{Hydride Transfer and HAT Reactivity of $1 \mathrm{H}^{-}$}

The reactivity of $1 \mathrm{H}^{-}$with different hydride and hydrogen atom acceptors was investigated by ${ }^{1} \mathrm{H}$ NMR spectroscopy. All the reaction mixtures were prepared in the glovebox under low temperature condition $\left(-30 \sim-35^{\circ} \mathrm{C}\right)$, and the reactions were monitored at $-30{ }^{\circ} \mathrm{C}$ or $25^{\circ} \mathrm{C}$. For a typical experiment, $\mathbf{1} \mathrm{H}^{-}$ was prepared in situ first. $8.0 \mathrm{mg}$ of $1(0.015 \mathrm{mmol})$ was weighted in an $8 \mathrm{~mL}$ vial. Next, $0.5 \mathrm{~mL}$ of [ $\left.\mathrm{HNEt}_{3}\right] \mathrm{PF}_{6}$ solution $\left(0.030 \mathrm{M}, 7.5 \mathrm{mg}\right.$ in $\left.1.0 \mathrm{~mL} \mathrm{MeCN}-d_{3}\right)$ was added to the vial, followed by another $0.5 \mathrm{~mL}$ of $1,3,5$-trimethoxybenzene solution $\left(0.030 \mathrm{M}, 10.2 \mathrm{mg}\right.$ in $\left.2.0 \mathrm{~mL} \mathrm{MeCN}-d_{3}\right)$ as an internal standard. Both [HNEt 3$] \mathrm{PF}_{6}$ and 1,3,5-trimethoxybenzene are 1.0 equiv with respect to 1 . The solution mixture was then cooled in the freezer. In another $8 \mathrm{~mL}$ vial, $11.5 \mathrm{mg}$ of $\mathrm{CoCp}_{2}$ were dissolved in 2.0 $\mathrm{mL}$ of $\mathrm{MeCN}-d_{3}(0.030 \mathrm{M})$, and the solution cooled down in the freezer. Then, $1.0 \mathrm{~mL}$ of the $\mathrm{CoCp}_{2}$ solution (2.0 equiv to $\mathbf{1}$ ) was added to the solution mixture containing $\mathbf{1},\left[\mathrm{HNEt}_{3}\right] \mathrm{PF}_{6}$ and $1,3,5-$ trimethoxybenzene, giving a $0.0076 \mathrm{M}$ stock solution of $\mathbf{1 H}^{-}$. $0.0076 \mathrm{M}$ stock solutions of $[\mathrm{Ph}-\mathrm{Acr}] \mathrm{ClO}_{4}$ (3.3 $\mathrm{mg}$ in $\left.1.170 \mathrm{~mL} \mathrm{MeCN}-d_{3}\right)$, TEMPO ${ }^{\bullet}\left(2.4 \mathrm{mg}\right.$ in $\left.2.0 \mathrm{~mL} \mathrm{MeCN}-d_{3}\right)$ and $2,4,6-\mathrm{TTBP}^{\bullet}(2.3 \mathrm{mg}$ in $1.153 \mathrm{~mL} \mathrm{MeCN}-d_{3}$ ) were prepared via a similar procedures. Then, $0.3 \mathrm{~mL}$ of each substrate stock solution was transferred into a separate J. Young NMR tube and cooled down in the freezer. Next, 0.3 $\mathrm{mL}$ of the pre-cooled stock solution of $1 \mathrm{H}^{-}$was added to each cold tube, followed by quick removal from the glovebox and immediate immersion in a liquid $\mathrm{N}_{2}$-isopropanol bath at around $-35{ }^{\circ} \mathrm{C}$ before NMR measurements. For the reaction of $1 \mathrm{H}^{-}$with [BIM] $\mathrm{PF}_{6}, 1 \mathrm{~mL}$ of the stock solution of $1 \mathrm{H}^{-}(0.0038$ M) was prepared and added to a pre-cooled vial containing $7.0 \mathrm{mg}[\mathrm{BIM}] \mathrm{PF}_{6}(0.019 \mathrm{mmol}, 5.0$ equiv). Afterwards, the solution mixture was handled as described above.

\section{Examination of the $\mathrm{CO}_{2}$ Reduction Catalysis Employing $\mathbf{1}$ and $\mathbf{2}$}

Since $f a c$ - $\left[\operatorname{Re}(\mathrm{bpy})(\mathrm{CO})_{3}(\mathrm{Cl})\right]$ type complexes are well-known for their ability to mediate the $\mathrm{CO}_{2}$-to$\mathrm{CO}$ reduction, we also investigated $\mathbf{1}$ and $\mathbf{2}$ as molecular electrocatalysts in $\mathrm{CO}_{2}$ reduction to assess the effect of the peripheral sulfuration. A previous report indicates certain reactivity of $\mathbf{1}$, though full examination has not been pursued so far. ${ }^{6} \mathrm{All} \mathrm{CV}$ experiments have been conducted at $-35^{\circ} \mathrm{C}$ and at $\mathrm{rt}$, 
whereas extended electrolysis has been conducted only at $-35^{\circ} \mathrm{C}$ as the reduced compound is not stable at $\mathrm{rt}$ for prolonged time (see main text). The $\mathrm{CV}$ data of $\mathrm{CO}_{2}$ saturated $\mathrm{MeCN}$ solutions of $\mathbf{1}$ and $\mathbf{2}$ reveal a moderate current increase at the potential of the second reduction process for both complexes (Figure S3 and S4, red traces).

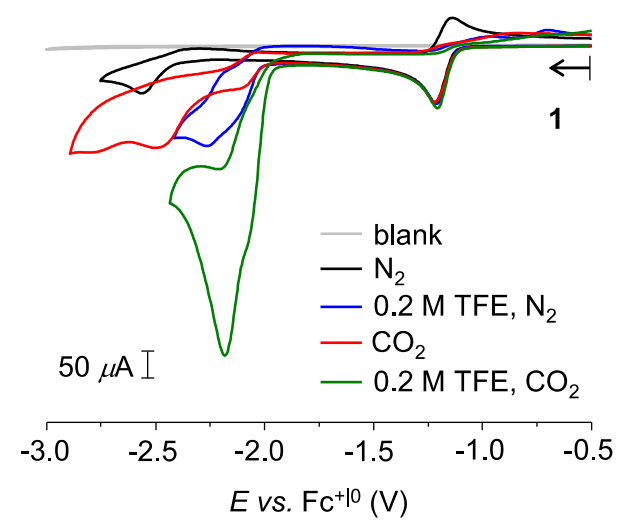

Figure S3. $C V$ data of blank (grey) and $1.0 \mathrm{mM} 1$ in MeCN. Black: under $\mathrm{N}_{2}$; blue: in presence of 0.2 $M T F E$ under $\mathrm{N}_{2}$; red: under $\mathrm{CO}_{2}$; green in presence of $0.2 \mathrm{MTFE}$ under $\mathrm{CO}_{2} . v=0.1 \mathrm{~V} \mathrm{~s}^{-1}$.

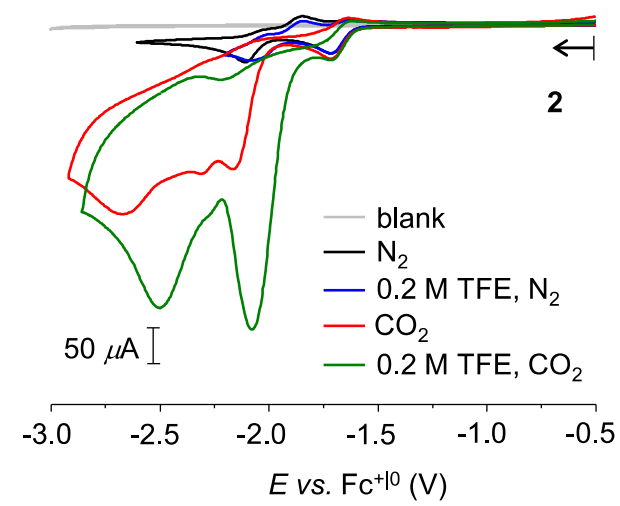

Figure S4. CV data of blank (grey) and $1.0 \mathrm{mM} 2$ in MeCN. Black: under $\mathrm{N}_{2}$; blue: in presence of 0.2 $M$ TFE under $\mathrm{N}_{2}$; red: under $\mathrm{CO}_{2}$; green in presence of $0.2 \mathrm{MTFE}$ under $\mathrm{CO}_{2} . v=0.1 \mathrm{~V} \mathrm{~s}^{-1}$.

Since Brønsted acids could enhance the activity, we further investigated catalysis in the presence of 0.2 $\mathrm{M}$ trifluoroethanol (TFE). Indeed, for $\mathbf{1}$ we observed a shift of the peak potential of the catalytic event to $E_{\mathrm{p}, \text { cat }}=-2.18 \mathrm{~V}$ with a shoulder at $-2.08 \mathrm{~V}\left(v=0.1 \mathrm{~V} \mathrm{~s}^{-1}\right.$, Figure S3, green trace). The peak potential of the catalytic event is near to the potential of the reductions of $1 \mathrm{H}^{-}$, indicating that reduction of $1 \mathrm{H}^{-}$ initiates catalysis. A steep current increase and a slight shift of the maximum peak potential in the presence of TFE was also observed in the CV data of $2\left(v=0.1 \mathrm{~V} \mathrm{~s}^{-1}\right.$, Figure S4, green trace).

The overpotential $\eta$ for the catalysis with $\mathbf{1}$ is slightly higher than with the parent complex $\left[\operatorname{Re}(\text { bpy })(\mathrm{CO})_{3} \mathrm{Cl}\right]^{7}$, presumably due to the negative charge of the complex (Table S3, detailed calculation see Section 2.1), while it is the same for 2 as for $\left[\operatorname{Re}(\mathrm{bpy})(\mathrm{CO})_{3} \mathrm{Cl}\right]$. The $i_{\text {cat }} / i_{\mathrm{p}}$ ratio, which serves as a measure for the all-over rate constant for catalysis, was determined to be 4.7 and 9.9 for $\mathbf{1}$ and 2, respectively, at $\mathrm{rt}, v=0.1 \mathrm{~V} \mathrm{~s}^{-1} \cdot{ }^{7,8} \mathbf{1}$ and $\mathbf{2}$ exhibit smaller $i_{\text {cat }} / i_{\mathrm{p}}$ ratio than the parent $\left[\mathrm{Re}(\right.$ bpy $\left.)(\mathrm{CO})_{3} \mathrm{Cl}\right] .{ }^{7}$ The Faraday efficiency for $\mathrm{CO}$ production was rather low with only $23 \%$ for $\mathbf{1}$ at $-35^{\circ} \mathrm{C}$.

Since the estimated hydricity of the proposed active species $\left[\mathrm{Re}\left({ }^{\mathrm{SHS}} \mathrm{bpy}\right)(\mathrm{CO})_{3}\right]^{2-}$ is sufficient to form formate, we also conducted experiments with ${ }^{13} \mathrm{CO}_{2}$. However, the ${ }^{13} \mathrm{C}$ NMR spectrum after electrolysis just showed ${ }^{13} \mathrm{CO}$ formation, but no other ${ }^{13} \mathrm{C}$-containing products. The hydricity of $\left[\operatorname{Re}\left({ }^{\mathrm{SHS}} \mathrm{bpy}\right)(\mathrm{CO})_{3}\right]^{2-}$ 
can be roughly estimated from the irreversible reduction potential of $1 \mathrm{H}^{-}$, the BDFE of $1 \mathrm{H}^{-}$and the redox potential of the $\mathrm{H}^{\bullet} \mid \mathrm{H}_{2}$ redox pair. ${ }^{9}$

Table S3. Catalytic key parameters for the $\mathrm{CO}_{2}$-to-CO reduction employing 1 and 2 as catalysts, $\mathrm{MeCN}$, $0.2 \mathrm{MTFE},\left[{ }^{n} \mathrm{Bu} \mathrm{N}_{4} \mathrm{~N}\right] \mathrm{PF}, \mathrm{v}=0.1 \mathrm{Vs}^{-1}$.

\begin{tabular}{lllll}
\hline & $\mathbf{1}$ & $\mathbf{1}$ & $\mathbf{2}$ & {$\left[\mathrm{Re}(\mathrm{CO})_{3}(\mathrm{bpy}) \mathrm{Cl}\right]^{\mathrm{a}}$} \\
& $-35{ }^{\circ} \mathrm{C}$ & $\mathrm{rt}$ & $\mathrm{rt}$ & $\mathrm{rt}^{\mathrm{a}}$ \\
\hline$\eta / \mathrm{V}$ & & 0.44 & 0.37 & $0.37^{\mathrm{a}}$ \\
$i_{\mathrm{d}} i_{\mathrm{p}}$ & 4.1 & 4.7 & 9.9 & $13.4^{\mathrm{a}}$ \\
$\mathrm{FE}(\mathrm{CO})$ & $23 \%$ & & & \\
\hline
\end{tabular}

a Values taken from ref 7.

2.1. Determination of the Overpotential and Reaction Rate of the $\mathrm{CO}_{2}$ Reduction Catalysis The standard potential for $\mathrm{CO}_{2} \mid \mathrm{CO}$ in $\mathrm{MeCN}+\mathrm{TFE}$ is calculated according to eq. (1).

$E_{\mathrm{CO}_{2} / \mathrm{CO}}^{\mathrm{MeCN}, \mathrm{TFE}}=E_{\mathrm{CO}_{2} / \mathrm{CO}}^{\mathrm{MeCN}}-0.0592 p K_{a}^{\mathrm{TFE}, \mathrm{MeCN}}=-1.61 \mathrm{~V}$

The standard reduction potential for $\mathrm{CO}_{2} \mid \mathrm{CO}$ in $\mathrm{MeCN}$ is $-0.12 \mathrm{~V}$ at $\mathrm{rt}^{10}{ }^{10}$ The effective $\mathrm{p} K_{\mathrm{a}}$ of TFE considering homoconjugation in $\mathrm{CO}_{2} / \mathrm{MeCN}$ is 25.1 at $\mathrm{rt}$ in $\mathrm{MeCN} .{ }^{11}$

The overpotential of the catalysis is determined from the half peak potential of the catalytic wave at 0.1 $\mathrm{Vs}^{-1}$ according to eq. (2). ${ }^{12}$

$\eta=\left|E_{\mathrm{CO}_{2} / \mathrm{CO}}^{\mathrm{MeCN}, \mathrm{TFE}}-E_{1 / 2, \text { cat }}^{\mathbf{1}}\right|$

$E_{1 / 2, \text {,at }}^{1, \mathrm{rt}}=-2.05 \mathrm{~V}$ $\rightarrow \quad \eta=0.44 \mathrm{~V}$

$E_{1 / 2, c a t}^{1,-35^{\circ} \mathrm{C}}=-2.02 \mathrm{~V}$

$E_{1 / 2}^{2}=-1.98 \mathrm{~V} \quad \rightarrow \quad \eta=0.37 \mathrm{~V}$

$E_{1 / 2}^{\mathrm{Re}(\mathrm{CO}) 3(\mathrm{bpy}) \mathrm{Cl}}=-1.98 \mathrm{~V}^{7} \rightarrow \quad \rightarrow \quad \eta=0.37 \mathrm{~V}$

The reaction rate of the catalytic event can be determined from the catalytic current under diffusion controlled, limiting catalytic current. ${ }^{13}$ However, this situation has not been reached in the current experiments and thus, the values just serve as an estimation of the catalysis.

$i_{c}=n_{c} \cdot F \cdot A \cdot C_{c a t} \sqrt{D} k_{c a t}^{\frac{1}{2}}$

Dividing $i_{\mathrm{c}}$ by $i_{\mathrm{p}}$, that is the current of a comparable, non-catalytic event, eliminates several constants and leads to eq. (5)

$i_{p}=0.4463 \cdot A \cdot C_{c a t} \cdot \sqrt{\frac{n_{p}^{3} \cdot F^{3} \cdot D}{R \cdot T}} v^{\frac{1}{2}}$

$\frac{i_{c}}{i_{p}}=\frac{n_{c}}{0.4463} \sqrt{\frac{R T}{n_{p}^{3} F v}} S^{x} k_{c a t}^{\frac{1}{2}}$

$A=$ electrode surface, $C_{\text {cat }}=$ catalyst concentration, $n=$ number of transferred electrons, $F=$ Faraday constant, $D=$ diffusion constant, $R=$ gas constant, $v=$ scan rate; $T=$ temperature, $\mathrm{S}=$ substrate concentration. ${ }^{13}$ 


\section{X-Ray Crystallography}

Crystal data and details of the data collections are given in Table S4, selected bond lengths and angles in Table S5. X-ray data were collected on a STOE IPDS II (monochromated Mo- $K_{\alpha}$ radiation, $\lambda=$ $0.71073 \AA$ ) by use of $\omega$ scans at low temperature. The structures were solved with SHELXT and refined on $F^{2}$ using all reflections with SHELXL-18. ${ }^{14}$ Non-hydrogen atoms were refined anisotropically. Hydrogen atoms were placed in calculated positions and assigned to an isotropic displacement parameter of $1.2 U_{\mathrm{eq}}(\mathrm{C})$. Face-indexed absorption corrections were performed numerically with the program XRED. $^{15}$

Table S4. Crystal data and refinement details for 1 and 2.

\begin{tabular}{|c|c|c|}
\hline empirical formula & $\mathrm{C}_{13} \mathrm{H}_{6} \mathrm{ClN}_{2} \mathrm{O}_{3} \operatorname{ReS}_{2}(\mathbf{1})$ & $\mathrm{C}_{13} \mathrm{H}_{6} \mathrm{ClN}_{2} \mathrm{O}_{3} \operatorname{ReS}(2)$ \\
\hline formula weight & 523.97 & 491.91 \\
\hline$T[\mathrm{~K}]$ & $133(2)$ & $133(2)$ \\
\hline crystal size $\left[\mathrm{mm}^{3}\right]$ & $0.44 \times 0.35 \times 0.21$ & $0.48 \times 0.28 \times 0.23$ \\
\hline crystal system & monoclinic & monoclinic \\
\hline space group & $P 2_{1} / n$ (No. 14$)$ & $C 2 / c$ (No. 15$)$ \\
\hline$a[\AA]$ & $11.8571(3)$ & $28.3437(10)$ \\
\hline$b[\AA]$ & $19.0709(4)$ & $11.2078(4)$ \\
\hline$c[\AA]$ & $13.2309(3)$ & $8.9328(3)$ \\
\hline$\alpha\left[^{\circ}\right]$ & 90 & 90 \\
\hline$\beta\left[^{\circ}\right]$ & $100.249(2)$ & $105.969(3)$ \\
\hline$\delta\left[{ }^{\circ}\right]$ & 90 & 90 \\
\hline$V\left[\AA^{3}\right]$ & 2944.11(12) & 2728.18(17) \\
\hline Z & 8 & 8 \\
\hline$\rho\left[\mathrm{g} \cdot \mathrm{cm}^{-3}\right]$ & 2.364 & 2.395 \\
\hline$F(000)$ & 1968 & 1840 \\
\hline$\mu\left[\mathrm{mm}^{-1}\right]$ & 8.731 & 9.266 \\
\hline$T_{\min } / T_{\max }$ & $0.2456 / 0.6015$ & $0.1518 / 0.3171$ \\
\hline$\theta$-range $\left[{ }^{\circ}\right]$ & $1.894-26.854$ & $1.495-26.717$ \\
\hline$h k l$-range & $\pm 15,-23$ to $24, \pm 16$ & -35 to $32, \pm 14, \pm 11$ \\
\hline measured refl. & 41383 & 16922 \\
\hline unique refl. $\left[R_{\text {int }}\right]$ & $6246[0.0394]$ & $2896[0.0296]$ \\
\hline observed refl. $(I>2 \sigma(I))$ & 5683 & 2815 \\
\hline data / restr. / param. & 6246 / 0 / 397 & 2896 / 0 / 190 \\
\hline goodness-of-fit $\left(F^{2}\right)$ & 1.142 & 1.192 \\
\hline$R 1, w R 2(I>2 \sigma(I))$ & $0.0289 / 0.0715$ & $0.0167 / 0.0436$ \\
\hline$R 1, w R 2$ (all data) & $0.0328 / 0.0730$ & $0.0174 / 0.0439$ \\
\hline res. el. dens. $\left[\mathrm{e} \cdot \AA^{-3}\right]$ & $-1.801 / 1.402$ & $-0.672 / 0.806$ \\
\hline
\end{tabular}


Table S5. Selected distances $[\AA]$ and angles $\left[{ }^{\circ}\right]$ of two crystallographic independent molecules observed in 1 and those of 2.

\begin{tabular}{lll}
\hline & $\mathbf{1} \mathbf{1}$ & $\mathbf{2}$ \\
\hline $\mathrm{Re} 1-\mathrm{N} 1 / \mathrm{Re} 2-\mathrm{N} 11$ & $2.175(4) / 2.171(4)$ & $2.211(2)$ \\
$\mathrm{Re} 1-\mathrm{N} 2 / \mathrm{Re} 2-\mathrm{N} 12$ & $2.166(4) / 2.186(4)$ & $2.215(2)$ \\
$\mathrm{Re} 1-\mathrm{C} 11 / \mathrm{Re} 2-\mathrm{C} 31$ & $1.918(6) / 1.913(6)$ & $1.922(3)$ \\
$\mathrm{Re} 1-\mathrm{C} 12 / \mathrm{Re} 2-\mathrm{C} 32$ & $1.924(6) / 1.918(6)$ & $1.908(3)$ \\
$\mathrm{Re} 1-\mathrm{C} 13 / \mathrm{Re}-\mathrm{C} 33$ & $1.921(6) / 1.916(6)$ & $1.918(3)$ \\
$\mathrm{Re} 1-\mathrm{C} 1 /$ Re2-C12 & $2.4737(14) / 2.4654(14)$ & $2.4879(7)$ \\
$\mathrm{C} 11-\mathrm{O} 1 / \mathrm{C} 31-\mathrm{O} 11$ & $1.153(7) / 1.145(7)$ & $1.133(4)$ \\
$\mathrm{C} 12-\mathrm{O} 2 / \mathrm{C} 32-\mathrm{O} 12$ & $1.147(7) / 1.152(7)$ & $1.167(4)$ \\
$\mathrm{C} 13-\mathrm{O} 3 / \mathrm{C} 33-\mathrm{O} 13$ & $1.129(7) / 1.136(7)$ & $1.147(4)$ \\
$\mathrm{S}-\mathrm{S}$ & $2.042(2) / 2.053(3)$ & \\
\hline $\mathrm{C} 11-\mathrm{Re} 1-\mathrm{C} 13 / \mathrm{Cl} 2-\mathrm{Re} 2-\mathrm{C} 33$ & $176.32(17) / 173.25(16)$ & $175.78(9)$ \\
$\mathrm{N} 1-\mathrm{Re} 1-\mathrm{C} 12 / \mathrm{N} 11-\mathrm{Re} 2-\mathrm{C} 32$ & $169.7(2) / 179.4(2)$ & $172.58(11)$ \\
$\mathrm{N} 2-\mathrm{Re} 1-\mathrm{C} 11 / \mathrm{N} 12-\mathrm{Re} 2-\mathrm{C} 31$ & $175.4(2) / 171.7(2)$ & $176.31(11)$ \\
$\mathrm{Re} 1-\mathrm{C} 11-\mathrm{O} 1 / \mathrm{Re} 2-\mathrm{C} 31-\mathrm{O} 11$ & $176.1(5) / 177.5(5)$ & $178.5(3)$ \\
$\mathrm{Re} 1-\mathrm{C} 12-\mathrm{O} 2 / \mathrm{Re} 2-\mathrm{C} 32-\mathrm{O} 12$ & $177.9(5) / 173.0(5)$ & $177.4(3)$ \\
$\mathrm{Re} 1-\mathrm{C} 13-\mathrm{O} 3 / \mathrm{Re} 2-\mathrm{C} 33-\mathrm{O} 13$ & $176.9(5) / 178.6(5)$ & $178.9(3)$ \\
$\mathrm{C}-\mathrm{S}-\mathrm{S}-\mathrm{C}$ & $55.9 / 57.8$ & \\
$\mathrm{~N}-\mathrm{C}-\mathrm{C}-\mathrm{N}$ & $8.6 / 3.8$ & 1.1 \\
\hline
\end{tabular}

\section{Thermodynamic Considerations}

\subsection{Determination of the $\mathrm{p} K_{\mathrm{a}}$ of $1 \mathrm{H}^{-}$}

The $\mathrm{p} K_{\mathrm{a}}$ of $\mathbf{1}^{2-}$ was determined according to a modified procedure of A. S. Borovik and co-workers. ${ }^{16}$ The equilibrium constant was determined at five representative wavelength assuming mass balance for 1 and the acid in the titration experiment (experimental detail, see UV-vis Spectroscopy), but accounting for dilution upon adding the acid and for homoconjugation of acetate.

The equilibrium constant can be determined from a titration experiment with an acid of which the $\mathrm{p} K_{\mathrm{a}}$ is known according to eq. (6).

\begin{tabular}{rlll}
$1^{2-}+\mathrm{AcOH}$ & $\rightleftharpoons \mathrm{1H}^{-}+\mathrm{AcO}^{-}$ & $K_{\mathrm{eq}}$ \\
\hline $1 \mathrm{H}^{-}$ & $\rightleftharpoons 1^{2-}+\mathrm{H}^{+}$ & $K_{1 \mathrm{H}}$ \\
$\mathrm{AcOH}$ & $\rightleftharpoons \mathrm{AcO}^{-}+\mathrm{H}^{+}$ & $K_{\mathrm{HOAc}}$
\end{tabular}

(6)

This allows for the calculation of the $\mathrm{p} K_{\mathrm{a}}$ according to eq (7).

$\frac{K_{\mathrm{HOAc}}}{K_{1 \mathrm{H}}}=K_{\mathrm{eq}}$

1. Determination of the concentration of $\mathbf{1}^{2-}$ at any given point $\mathrm{x}$ of the experiment

The extinction coefficients $\varepsilon_{0, \mathrm{~nm}}$ of $\mathbf{1}^{2-}$ and of of $\mathbf{1 H}^{-}$was determined at each wavelength according to Beer-Lambert law, eq. (8).

$A b s=\varepsilon_{\mathrm{nm}} \cdot l \cdot c_{1}$

$l=$ Optical path length

$c=$ Concentration of $\mathbf{1}^{2-}$ 
The acid was added gradually, which leads to the formation of $1 \mathrm{H}^{-}$in an equilibrium reaction. The concentration of $\mathbf{1}^{2-}$ at any given point $\mathrm{x}$ of the titration experiment was determined from the absorption spectra according to eq. (9).

$\left[\mathbf{1}^{2-}\right]_{x}=\frac{\varepsilon_{\mathrm{nm}, x}-\varepsilon_{1, \mathrm{~nm}}}{\varepsilon_{1, \mathrm{~nm}}-\varepsilon_{1 \mathrm{H}, \mathrm{nm}}} \cdot c_{1 \text { total }, x}$

$c_{1 \text { total }, x}$ : Total concentration of protonated and non-protonated complex $\mathbf{1}$ at any given point $\mathrm{x}$ of the titration experiment (accounting for dilution).

$\varepsilon_{\mathrm{nm}, x}$ : Extinction coefficient of the mixture of $\mathbf{1}^{2-}$ and $1 \mathrm{H}^{-}$at the respective wavelength at any given point $\mathrm{x}$ of the titration.

$\varepsilon_{1, \mathrm{~nm}}$ : Extinction coefficient of $\mathbf{1}^{2-}$ at the respective wavelength

$\varepsilon_{1 \mathrm{H}, \mathrm{nm}}$ : Extinction coefficient of $1 \mathrm{H}^{-}$at the respective wavelength.

$\left[\mathbf{1}^{2-}\right]_{x}$ : concentration of $\mathbf{1}^{2-}$ at any given point $\mathrm{x}$ of the titration experiment.

2. Determination of the concentration of $\mathbf{1 H}^{-}$at any given point $\mathrm{x}$ of the experiment

Assuming mass balance for $\mathbf{1}$, the sum of the amount of $1 \mathrm{H}^{-}$and $\mathbf{1}^{2-}$ at any given point $\mathrm{x}$ of the titration is equal to the initial amount of $\mathbf{1}^{2-}$ as described by eq. (10).

$c_{[1] \mathrm{total}, x}=\left[\mathbf{1 H}^{-}\right]_{x}+\left[\mathbf{1}^{2-}\right]_{x}$

Thus, the concentration of $1 \mathrm{H}^{-}$at any point $\mathrm{x}$ of the titration experiment calculates according to eq. (11).

$\left[\mathbf{1 H}^{-}\right]_{x}=c_{[1] \text { total }, x}-\left[\mathbf{1}^{2-}\right]_{x}$

3. Determination of the concentration of acetate, acetic acid and the homoconjugate at any given point $\mathrm{x}$ of the experiment

In the experiment, we determined the equilibrium concentrations of $\mathbf{1}^{2-}$ and $\mathbf{1 H}^{-}$after addition of substochiometric amounts of acetic acid. Since the acetate anion is not stabilized very well by acetonitrile, there is a reasonable driving force to form the homoconjugate $\left(\mathrm{AcO}^{-} \cdots \mathrm{HOAc}\right)^{17}$, and thus, we considered this in the concentration of acetate and acetic acid.

$$
\mathrm{AcO}^{-}+\mathrm{HOAC} \rightleftharpoons\left(\mathrm{AcO}^{-} \cdot \mathrm{HOAc}\right) \quad \log K_{\mathrm{c}}=3.9
$$

Thus, the equilibrium, which was measured, includes the equilibrium of the homoconjugation of acetate.

\begin{tabular}{rlll}
$1^{2-}+2 \mathrm{AcOH}$ & $\rightleftharpoons$ & $1^{-}+\left(\mathrm{AcO}^{-} \cdot \mathrm{HOAc}\right)$ & $K_{\exp }$ \\
\hline $1^{-}$ & $\rightleftharpoons 1^{2-}+\mathrm{H}^{+}$ & $K_{1 \mathrm{H}}$ \\
$\mathrm{AcOH}$ & $\rightleftharpoons \mathrm{AcO}^{-}+\mathrm{H}^{+}$ & $K_{\mathrm{HOAc}}$ \\
$\mathrm{AcO}^{-}+\mathrm{AcOH}$ & $\rightleftharpoons\left(\mathrm{AcO}^{-} \cdots \mathrm{HOAc}\right)$ & $K_{\mathrm{c}}$
\end{tabular}

Assuming mass balance also for the acid, the total concentration of acid, conjugated base and the homoconjugate is equal to the amount of the acid added at any point of the titration experiment according to eq. (13).

$c_{\text {acid,total }, x}=[\mathrm{AcOH}]_{x}+\left[\mathrm{AcO}^{-}\right]_{x}+2\left[\mathrm{AHA}^{-}\right]_{x}$

$\mathrm{AHA}^{-}$denotes the homoconjugate.

$c_{\mathrm{AcO} / \mathrm{AcOH}, \mathrm{total}, x}$ : Hypothetic concentration of the acid in solution calculated from the amount $n$ of acid that was added. 
The concentration of acetate, that is formed in the equilibrium reaction, is given by the concentration of free acetate and the acetate in the homoconjugate according to eq. (14).

$\left[\mathrm{AcO}^{-}, \mathrm{AHA}^{-}\right]_{\text {total }, x}=\left[\mathrm{AcO}^{-}\right]_{x}+\left[\mathrm{AHA}^{-}\right]_{x}$

The concentration of acetate and the homoconjugate, that is $\left[\mathrm{AcO}^{-}, \mathrm{AHA}^{-}\right]_{\text {total }, x}$, is equal to the concentration of $1 \mathrm{H}^{-}$at any given point of the titration experiment, eq. (15).

$\left[\mathbf{1 H}^{-}\right]_{x}=\left[\mathrm{AcO}^{-}, \mathrm{AHA}^{-}\right]_{\text {total }, x}$

The equilibrium constant of the homoconjugation is given by eq. (16).

$K_{\mathrm{c}}=\frac{\left[\mathrm{AHA}^{-}\right]}{[\mathrm{AcOH}] \cdot\left[\mathrm{AcO}^{-}\right]}$

Combining and rearranging of eq. (9), (10), (11), and (12) allows for the calculation of the concentration of the homoconjugate at any point of the titration experiment according to eq. (17).

$$
\left[\mathrm{AHA}^{-}\right]_{x}=-\left(\frac{-c_{\text {acid,total }, x}-\frac{1}{K_{\mathrm{c}}}}{2}\right)-\sqrt{\left(\frac{-c_{\text {acid,total }, x-\frac{1}{K_{\mathrm{c}}}}}{2}\right)^{2}-\left(c_{\text {acid,total }, x}\left[\mathbf{1} \mathrm{H}^{-}\right]_{x}-\left[\mathbf{1 H}^{-}\right]_{x}^{2}\right)}
$$

The concentration of the homoconjugate allows for the calculation of the concentration of the conjugated base by rearranging eq. (14) and (15).

$\left[\mathbf{1 H}^{-}\right]_{x}-\left[\mathrm{AHA}^{-}\right]_{x}=\left[\mathrm{AcO}^{-}\right]_{x}$

In turn, the concentration of the acid can be calculated by rearranging eq. (13).

$c_{\mathrm{AcO} / \mathrm{AcOH}, \text { total }, x}-\left[\mathbf{1 H}^{-}\right]_{x}-2\left[\mathrm{AHA}^{-}\right]_{x}=[\mathrm{AcOH}]_{x}$

The equilibrium constant $K_{\text {eq }}$ as shown in eq (6) was determined by linearization of the plot:

$[\mathrm{AcOH}]_{x} K_{\mathrm{eq}}=\frac{\left[\mathrm{AcO}^{-}\right]_{x} \cdot\left[\mathbf{1 H}^{-}\right]_{x}}{\left[\mathbf{1}^{\mathbf{2}}\right]_{x}}$

Table S6. $K_{\mathrm{eq}}$ at various wavelengths $/ \mathrm{nm}$.

\begin{tabular}{ll}
\hline wavelength & $K_{\text {eq }}$ \\
\hline 488 & 15.60 \\
495 & 15.58 \\
520 & 15.02 \\
560 & 14.31 \\
540 & 14.83 \\
\hline
\end{tabular}

The average value for $K_{\text {eq }}$ was determined to be 15.1 with a standard deviation $3 \sigma$ of 1.5 .

\subsection{Temperature Dependence of the Equilibrium Constant}

In general, the temperature dependency of the acid dissociation constant is given by the entropy of the ionization (eq. 21).

$-(\partial G / \partial T)_{p}=\Delta S$

Substitution of eq. (22) in eq. (21) leads to eq. (23).

$\Delta G=2.303 R T \cdot p K_{a}$ 
$-\left(\frac{\partial p K_{a}}{\partial T}\right)=\frac{p K_{a}}{T}+\frac{\Delta S}{2.303 R T}=\frac{p K_{a}+0.22 \Delta S}{T}$

Since the equilibrium constant between two acids/conjugated base pairs was measured, eq. (23) turns to eq. (24).

$-\left(\frac{\partial p K_{e q}}{\partial T}\right)=\frac{p K_{e q}}{T}+\frac{\Delta S_{e q}}{2.303 R T}=\frac{p K_{e q}+0.22 \Delta S_{e q}}{T}$

The $\mathrm{p} K_{\text {eq }}$ of $1 \mathrm{H}^{-}$is given by rearranging eq. (7) to eq. (25) and thus, the temperature dependence of the $\mathrm{p} K_{\mathrm{a}}$ is given by eq. (26)

$\mathrm{p} K_{\mathrm{a}, \mathrm{AcOH}}-\mathrm{p} K_{\mathrm{a}, 1 \mathrm{H}-}=\mathrm{p} K_{\mathrm{eq}}$

$-\left(\frac{\partial p K_{\mathrm{eq}}}{\partial T}\right)=\frac{p K_{a, A c O H}-p K_{a, 1 H-}}{T}+\frac{\Delta S_{\mathrm{eq}}}{2.303 R T}=\frac{p K_{a, A c O H}-p K_{a, 1 H^{-}}+0.22\left(\Delta S_{A c O H}-\Delta S_{1 H^{-}}\right)}{T}$

Since both of the basic sites are anionic group 16 elements, we assume that the temperature dependence in both acids is similar and thus cancels out. Consequently, the $\mathrm{p} K_{\mathrm{a}}$ of $1 \mathrm{H}^{-}$as calculated according to eq. (27) serves as an estimation of the $\mathrm{p} K_{\mathrm{a}}$ at $\mathrm{rt}$ as the $\mathrm{p} K_{\mathrm{a}}$ of acetic acid at $\mathrm{rt}$ is used as reference value.

Rearranging eq. (7) to eq. (21) leads to the $\mathrm{p} K_{\mathrm{a}}$ of $1 \mathrm{H}^{-}$as given in eq. (27)

$\mathrm{p} K_{\mathrm{a}, 1 \mathrm{H}-}=\mathrm{p} K_{\mathrm{a}, \mathrm{AcOH}}+\log K_{\mathrm{eq}}$

Acetic acid has a $\mathrm{p} K_{\mathrm{a}}$ of 23.51 at rt, ${ }^{18}$ which leads to a $\mathrm{p} K_{\mathrm{a}}$ of 24.7 for $1 \mathrm{H}^{-}$.

\subsection{Hydricity and BDFE}

The determination of the hydricity and the BDFE of $1 \mathrm{H}^{-}$follows the thermodynamic cycles as shown in Scheme $\mathrm{S} 1 .^{19}$

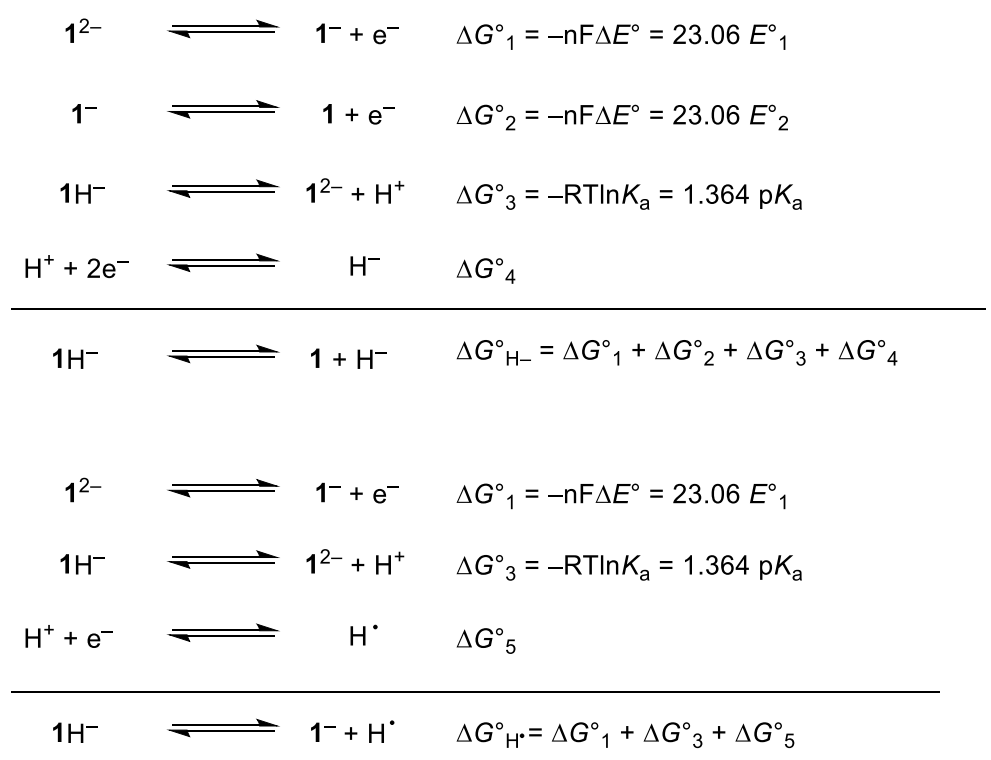

Scheme 1. Thermodynamic cycles to determine the hydricity (top) and the BDFE (bottom).

Table S7. Solution free energies for the reduction of $\mathrm{H}^{+}$in dmso and MeCN.

\begin{tabular}{lll}
\hline & dmso & MeCN \\
\hline$\Delta G^{\circ}{ }_{4,(\mathrm{H}+\mid \mathrm{H}-)} / \mathrm{kcal}^{\circ} \mathrm{mol}^{-1}$ & $71.4^{20}$ & $79.6^{21}$ \\
$\Delta G_{5,\left(\mathrm{H}+\mathrm{H}^{\circ}\right)} / \mathrm{kcal} \cdot \mathrm{mol}^{-1}$ & $71.1^{22}$ & $52.6^{23}$ \\
\hline
\end{tabular}


The isodesmic hydricity of $\mathrm{PhSH}$ and $\mathrm{PhS}^{-}$forming $\mathrm{Ph}_{2} \mathrm{~S}_{2}$ and $\mathrm{H}^{-}$can be calculated according to the thermodynamic cycle shown in Scheme $\mathrm{S} 2$. The values for $\Delta G^{\circ}{ }_{1}-\Delta G^{\circ}{ }_{5}$ have been taken from literature, Table S8. The solution free energies $\Delta G^{\circ}{ }_{5,(\mathrm{H}+\mid \mathrm{H} \cdot)}$ of the $\mathrm{H}$ atom formation in dmso and MeCN differ by $18.5 \mathrm{kcal} \cdot \mathrm{mol}^{-1}$ (Table S7). However, this is mainly an effect of the difference in the proton solvation in the different media and thus, compensated by the $\mathrm{p} K_{\mathrm{a}}$ values of $\mathrm{PhSH}$ and $1 \mathrm{H}^{-}$, as these also include the solvation free energy difference of $\mathrm{H}^{+}$as outlined in Scheme 4 of the main text $\left(\Delta G_{\text {sol, } \mathrm{H}+}=15.7\right.$ $\left.\mathrm{kcal} \cdot \mathrm{mol}^{-1}, \Delta G_{\mathrm{pKa}, \mathrm{S}-\mathrm{H}}=19.6 \mathrm{kcal} \cdot \mathrm{mol}^{-1}\right)$. ${ }^{24}$ The solution bond dissociation energy of $\mathrm{Ph}_{2} \mathrm{~S}_{2}$ has been determined to be $55 \mathrm{kcal} \cdot \mathrm{mol}^{-1}$ from the oxidation potential of $\mathrm{PhS}^{-}$in $\mathrm{dmf}$, which is given with $0.3 \mathrm{~V}^{22}$ vs. NHE $\left(=-0.4\right.$ vs. $\left.\mathrm{Fc}^{+10}\right) .^{25}$ The value is similar to the oxidation potential of $\mathrm{PhS}^{-}$in dmso, which is given with $-0.36 \mathrm{~V}^{22} v s$. $\mathrm{Fc}^{+10}$ and thus, it serves as a reasonable estimate also in dmso.

\begin{tabular}{|c|c|c|c|}
\hline $\mathrm{PhS}^{-}$ & $\mathrm{PhSH}$ & $\mathrm{Ph}_{2} \mathrm{~S}_{2}$ & $\mathrm{H}^{-} \quad \Delta G^{\circ}{ }_{5}$ \\
\hline $2 \mathrm{PhS}^{\circ}$ & $\rightleftharpoons$ & $\mathrm{Ph}_{2} \mathrm{~S}_{2}$ & $\Delta G_{1}=-R T \ln K$ \\
\hline $\mathrm{PhS}^{-}$ & $\rightleftharpoons$ & $\mathrm{PhS}^{\circ}+\mathrm{e}^{-}$ & $\Delta G_{2}^{\circ}=-\mathrm{nF} \Delta E^{\circ}=23.06 E_{1}^{\circ}$ \\
\hline $\mathrm{PhSH}$ & $\rightleftharpoons$ & $\mathrm{PhS}^{-}+\mathrm{H}^{+}$ & $\Delta G^{\circ}{ }_{3}=-R T \ln K_{\mathrm{a}}=1.364 \mathrm{p} K_{\mathrm{a}}$ \\
\hline $\mathrm{H}^{+}+2 \mathrm{e}^{-}$ & $\Longrightarrow$ & $\mathrm{H}^{-}$ & $\Delta G^{\circ}{ }_{4}$ \\
\hline
\end{tabular}

$\Delta G^{\circ}{ }_{H-}=\Delta G^{\circ}{ }_{1}+2 \Delta G^{\circ}{ }_{2}+\Delta G^{\circ}{ }_{3}+\Delta G_{4}^{\circ}$

Scheme S2. Hydricity $\Delta G^{\circ}{ }^{-}$for the isodesmic reaction of $\mathrm{PhSH}$ and $\mathrm{PhS}^{-}$.

Table S8. Hydricity and BDFE for PhSH/PhS .

\begin{tabular}{ll}
\hline & $\mathrm{PhSH} / \mathrm{PhS}^{-}$ \\
\hline Solvent & $\mathrm{dmso}$ \\
$E_{1} / \mathrm{V}$ & $-0.36 \mathrm{~V}^{22}$ \\
$\mathrm{p} K_{\mathrm{a}}$ & $10.3^{22}$ \\
$\Delta G^{\circ}{ }_{1} / \mathrm{kcal} \cdot \mathrm{mol}^{-1}$ & $-55^{25}$ \\
$\mathrm{BDFE} / \mathrm{kcal} \cdot \mathrm{mol}^{-1}$ & $77^{22}(\mathrm{PhSH})$ \\
Hydricity $/ \mathrm{kcal} \cdot \mathrm{mol}^{-1}$ & 14 \\
\hline
\end{tabular}




\section{Spectroscopic Data}

5.1. Electrochemistry

(a)
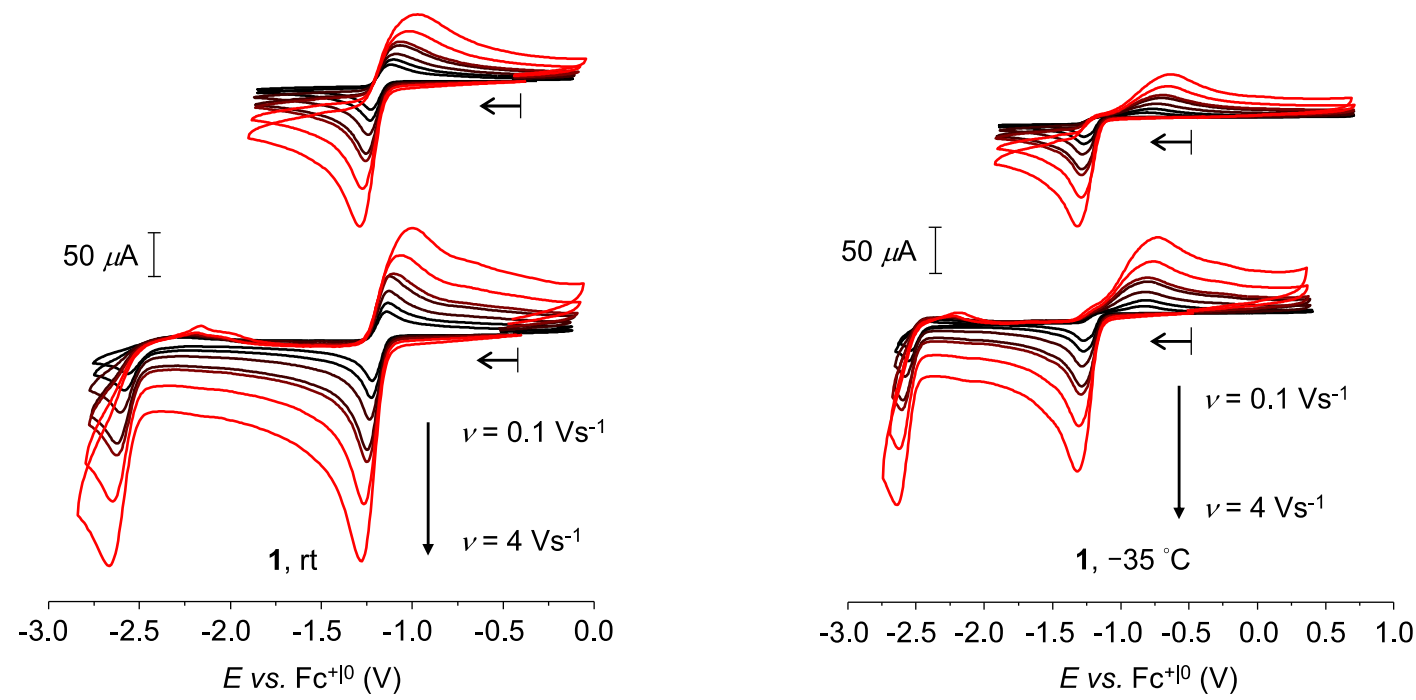

(b)

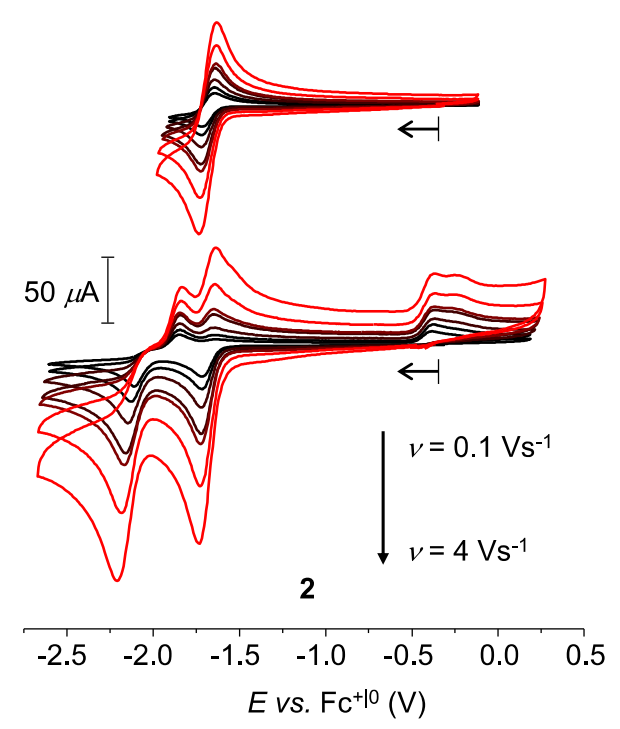

Figure S5. Scan rate dependent $C V$ data of (a) 1 at $r t$ and $-35^{\circ} \mathrm{C}$ and (b) 2 at rt under $N_{2}$ in dry MeCN, $c \approx 1 \mathrm{~m} \mathrm{M}, 0.1 \mathrm{M}\left[{ }^{n} B u_{4} N\right] P F_{6}, v=0.1,0.2,0.4,0.8,1,2$ and $4 \mathrm{Vs}^{-1}$. The corresponding CVs for the $1^{s t}$ reduction event are shown on top. 
(a)

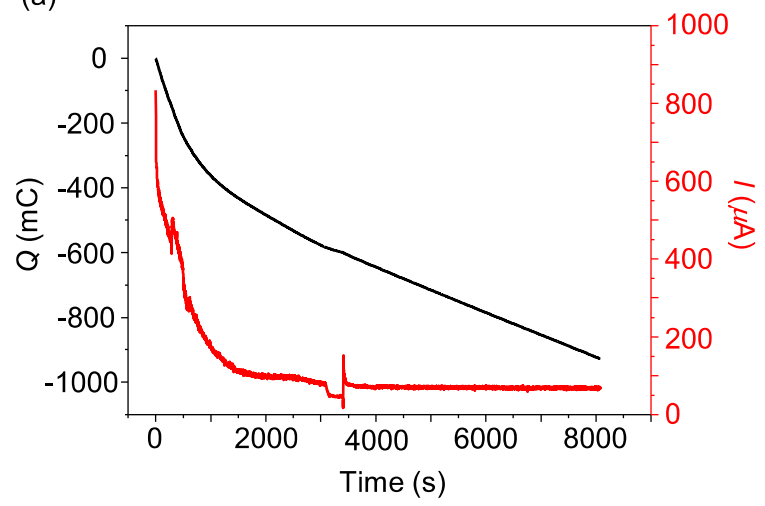

(c)

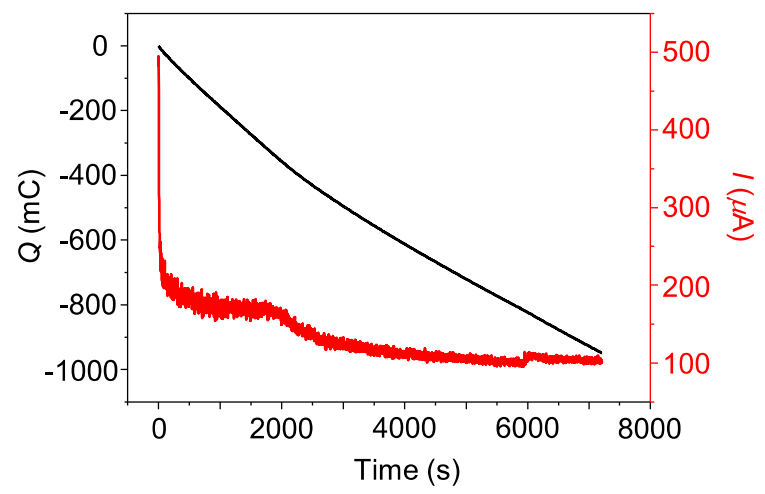

(b)

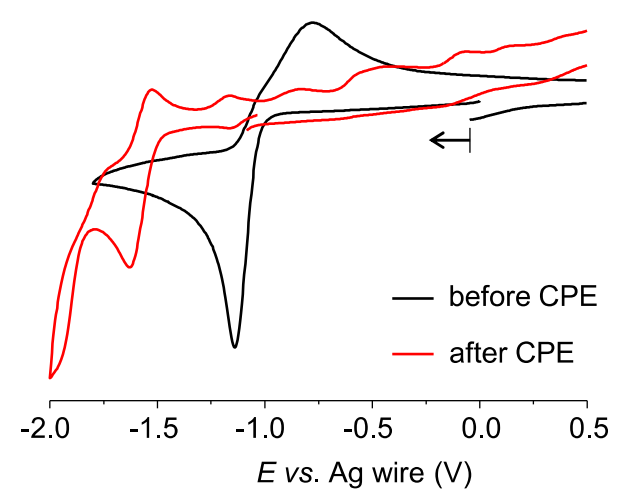

(d)

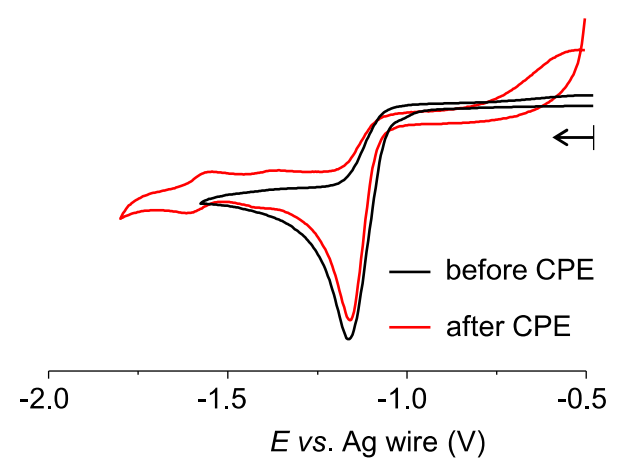

Figure S6. (a) Controlled potential electrolysis (CPE) of 1 in presence of $0.2 \mathrm{M}$ TFE at rt. The potential is set at $-1.4 \mathrm{~V}$ vs. silver wire, which matches the potential of the first reduction event. $I=0.2 \mathrm{M}$ $\left[{ }^{n} B u_{4} N\right] P F_{6}, M e C N, G C$ rod as working electrode. (b) CV data of 1 before and after the CPE. (c-d) Same experiments performed at $-35^{\circ} \mathrm{C}$.

(a)

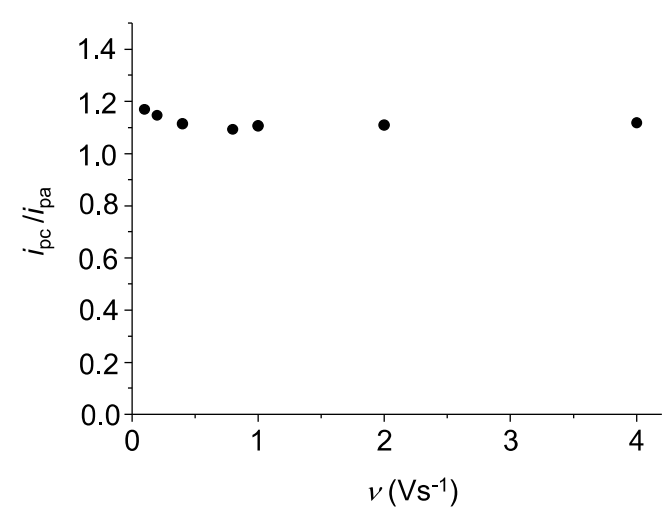

(b)

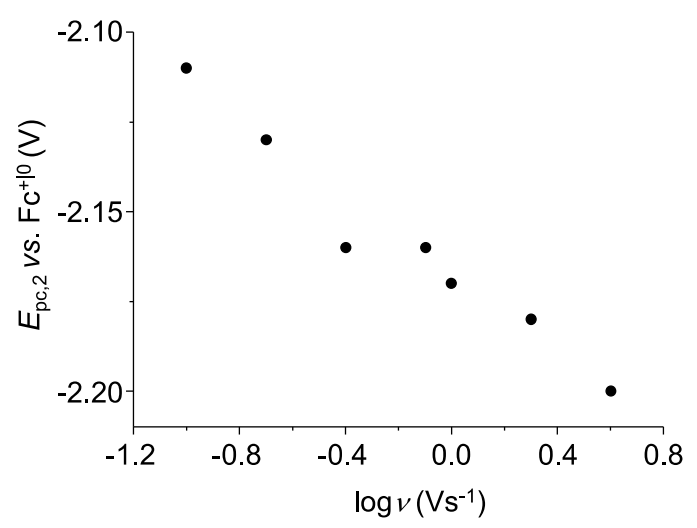

Figure S7. (a) Current of the cathodic over the anodic peak vs. the scan rate of the first reduction process of $\mathbf{2}$ and (b) peak potential of the second reduction process vs. the scan rate of 2. 


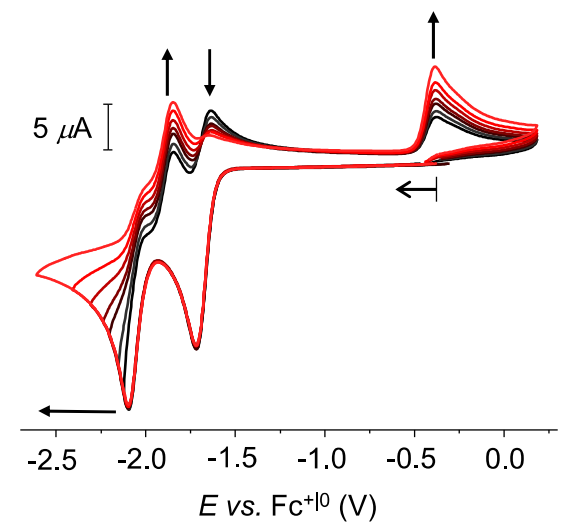

Figure S8. Multi scans of CV data of 2 in $M e C N, c=1 \mathrm{~m} \mathrm{M}, 0.1 \mathrm{M}\left[{ }^{n} B u_{4} N\right] P F_{6}$, with different switching potentials after the second cathodic process. When shifting the inversion potential gradually towards more negative voltages after the second reduction event of 2 , the first and third anodic peak heights increase at the expense of that of second peak.

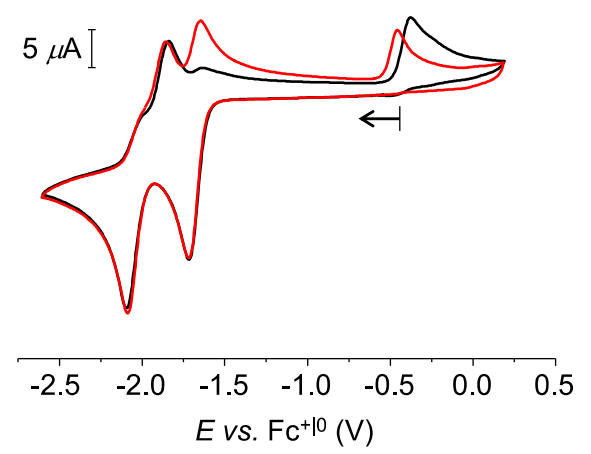

Figure S9. CV data of 2 in $\mathrm{MeCN}, c=1 \mathrm{mM}, 0.1 \mathrm{M}\left[{ }^{n} \mathrm{~B} u_{4} N\right] P F_{6}$, with 100 equiv [ $\left.{ }^{n} \mathrm{Bu}{ }_{4} \mathrm{~N}\right] \mathrm{Cl}$ (red) and without (black). $v=0.1 \mathrm{Vs}^{-1}$. 

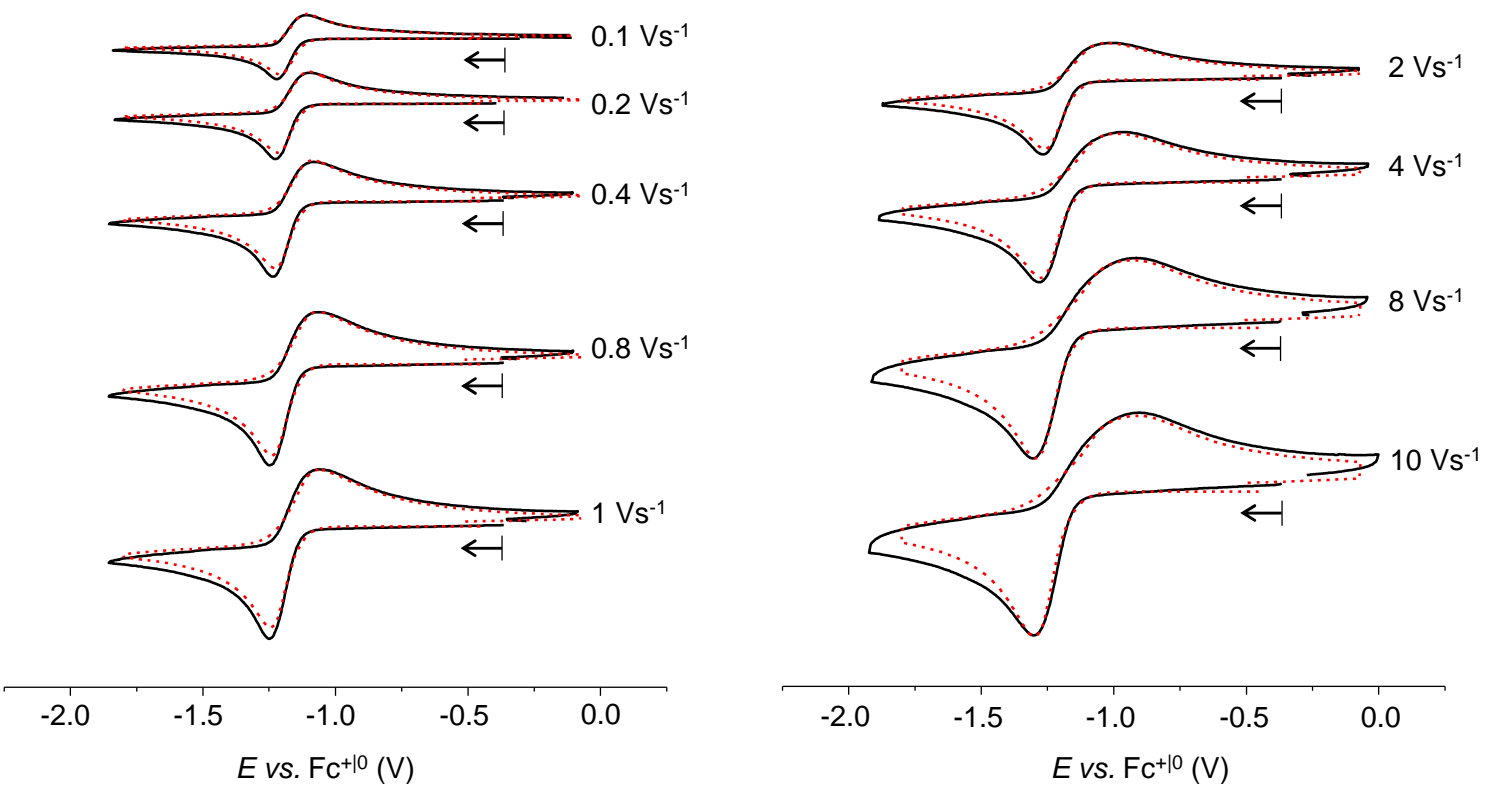

Figure S10. Experimental (black lines) and simulated (red dashed line) CV data of 1 in MeCN, $0.1 \mathrm{M}$ $\left[{ }^{n} \mathrm{Bu}{ }_{4} N\right] P F_{6}, T=298 \mathrm{~K}$; parameters: see Table 1.
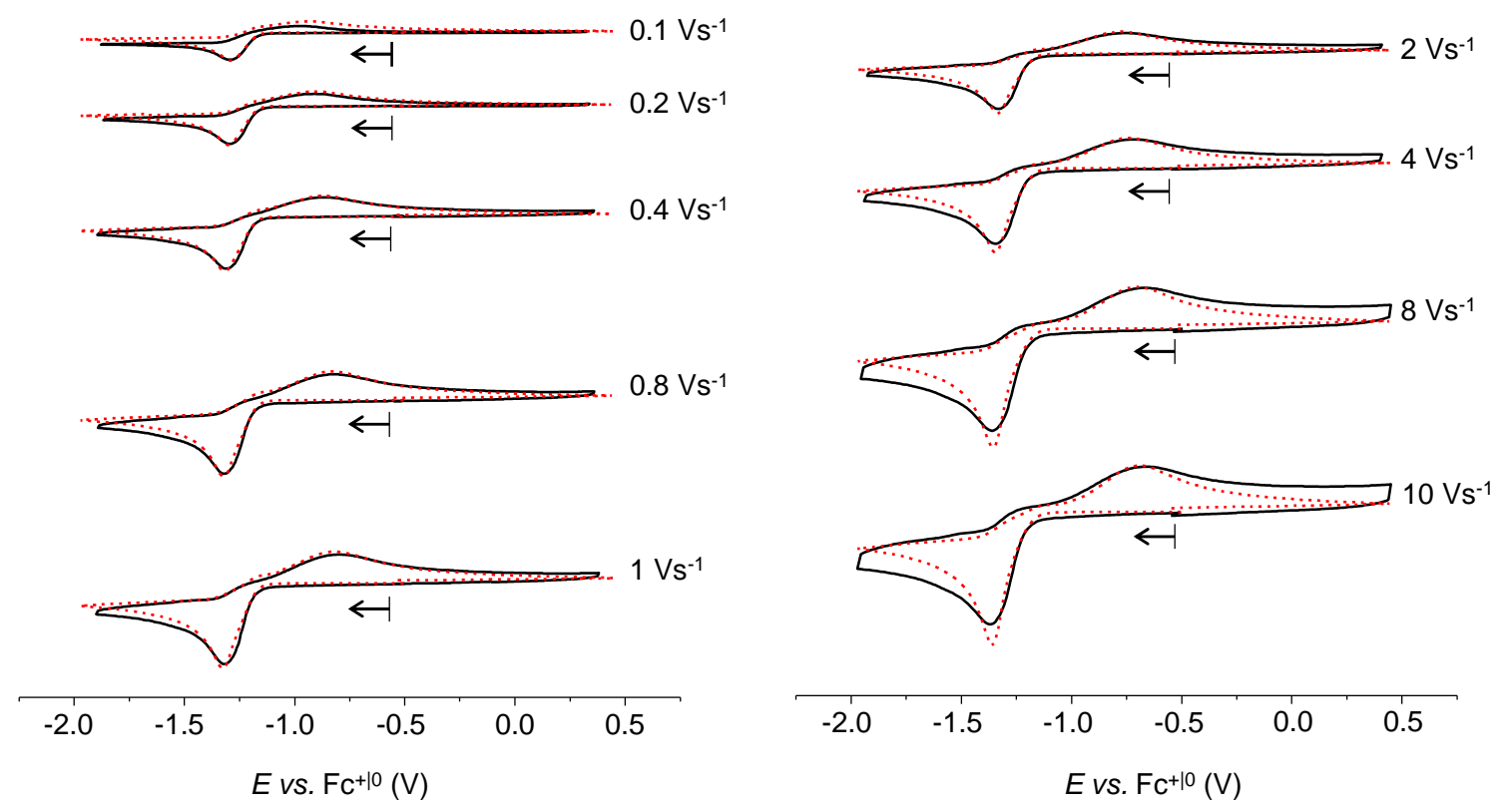

Figure S11. Experimental (black lines) and simulated (red dashed line) CV data of 1 in MeCN, $0.1 \mathrm{M}$ $\left[{ }^{n} \mathrm{Bu}_{4} \mathrm{~N}\right] P F_{6}, \mathrm{~T}=238 \mathrm{~K}$; parameters: see Table 1 . 


\subsection{UV-vis Spectra}

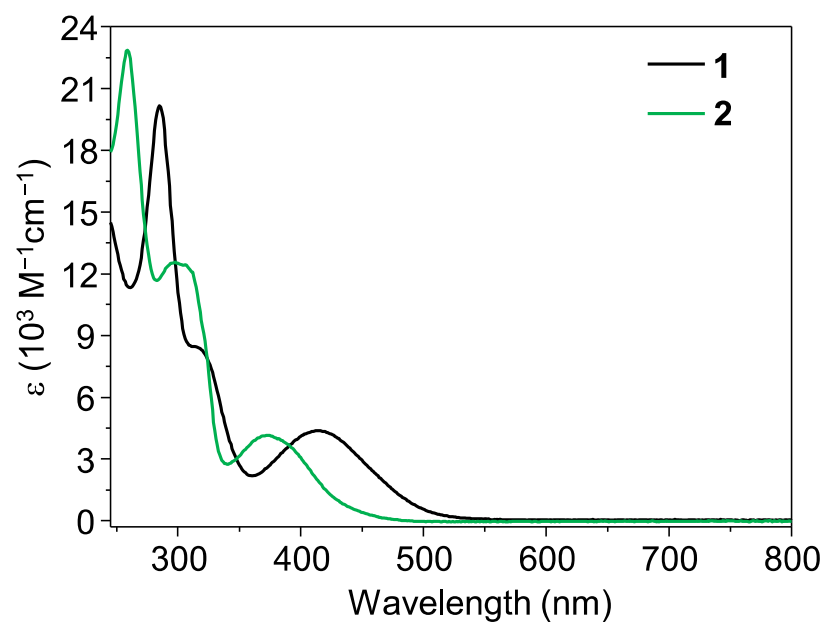

Figure S12. UV-vis spectra of 1 and 2 in MeCN at $298 \mathrm{~K}$.

(a)

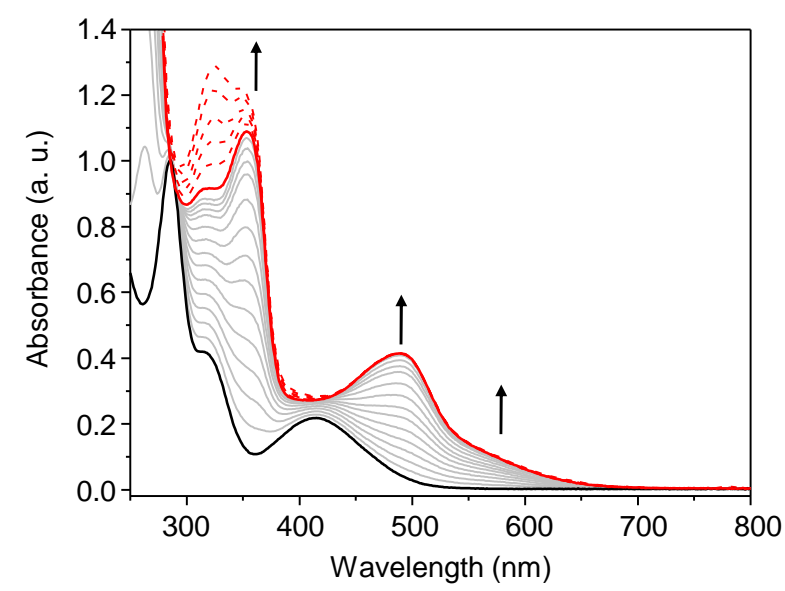

(b)

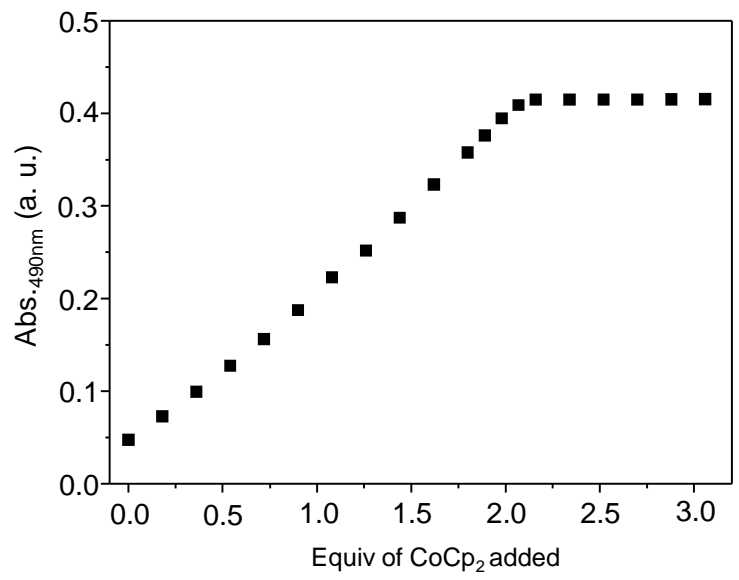

Figure S13. (a) UV-vis spectra of the titration experiment of 1 with $\mathrm{CoCp}_{2}$ (0.18 equiv per addition) at $-30{ }^{\circ} \mathrm{C}$ in MeCN. Black trace: start, solid red trace: after 2 equiv of $\mathrm{CoCp}_{2}$, dashed red traces: overtitration. (b) Absorbances at $490 \mathrm{~nm}$ during the experiment. 
(a)

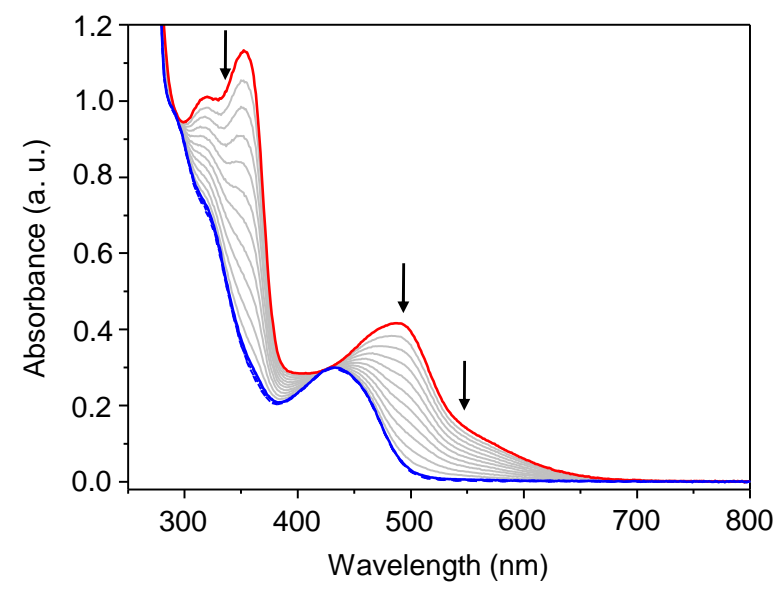

(b)

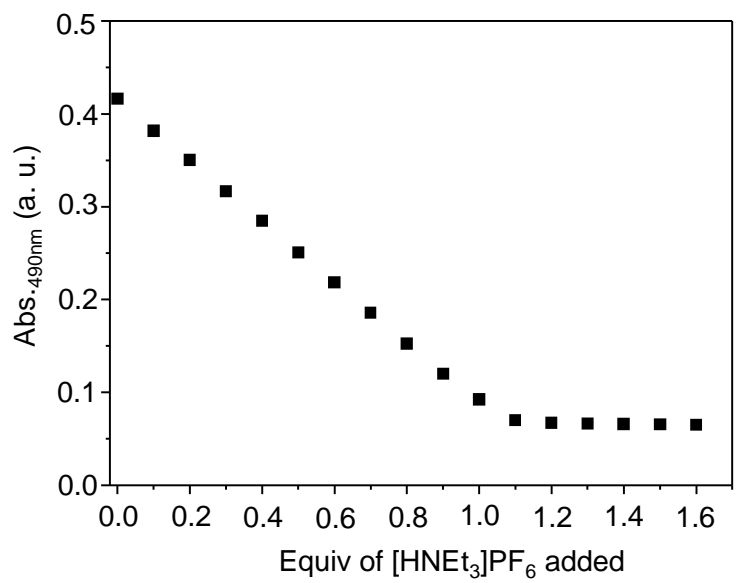

Figure S14. (a) UV-vis spectra of the titration experiment of $\mathbf{1}^{2-}$ with $\left[H N E t_{3}\right] P F_{6}$ (0.1 equiv per addition) at $-30{ }^{\circ} \mathrm{C}$ in MeCN. Start: red trace, end: blue trace. (b) Absorbances at $490 \mathrm{~nm}$ during the experiment.

(a)

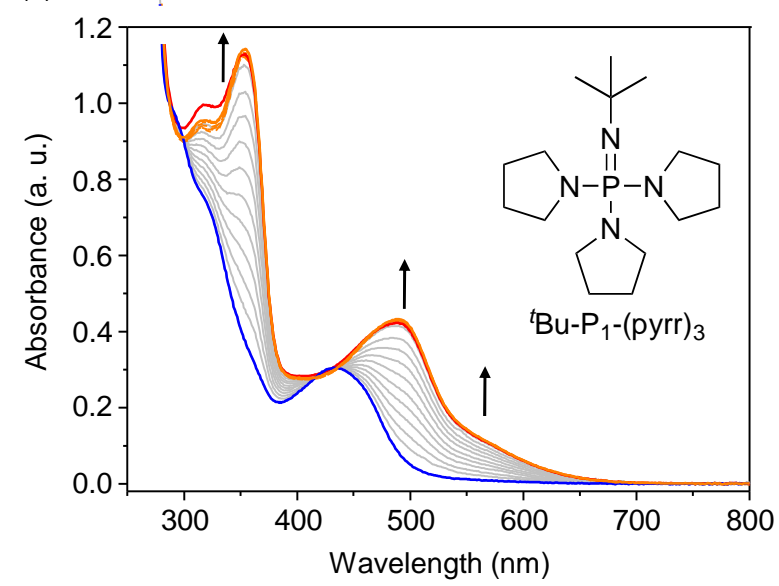

(b)

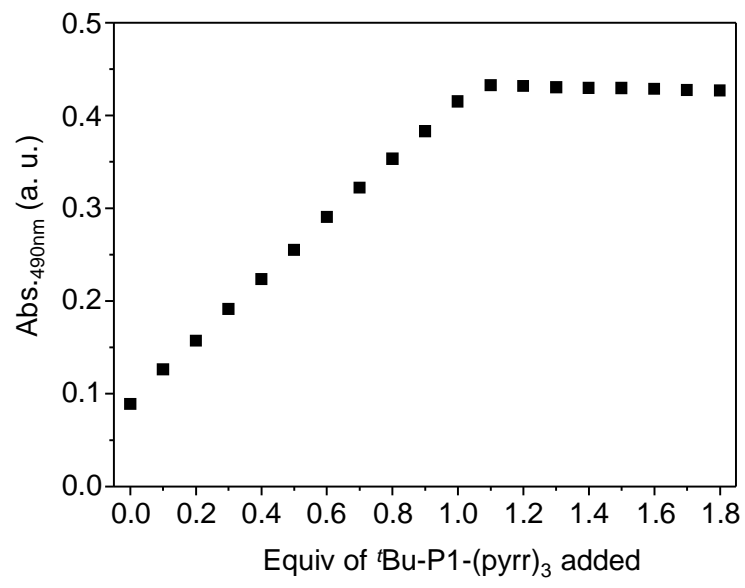

Figure S15. (a) UV-vis spectra of the titration experiment of $1 \mathrm{H}^{-}$with ${ }^{t} \mathrm{Bu}-\mathrm{Pl}-(\mathrm{pyrr})_{3}(0.1$ equiv per addition) at $-30{ }^{\circ} \mathrm{C}$ in MeCN. Start: blue trace, end: orange trace. (b) Absorbances at $490 \mathrm{~nm}$ during the experiment. The final spectrum is coincident with the doubly reduced $\mathbf{1}^{2-}$ (red trace), indicative of fully deprotonation of $1 \mathrm{H}^{-}$with the strong base ${ }^{t} \mathrm{Bu}-\mathrm{P}_{1-}$ (pyrr $)_{3}$. 


\subsection{NMR Spectra}

5.3.1. Reactivity Studies

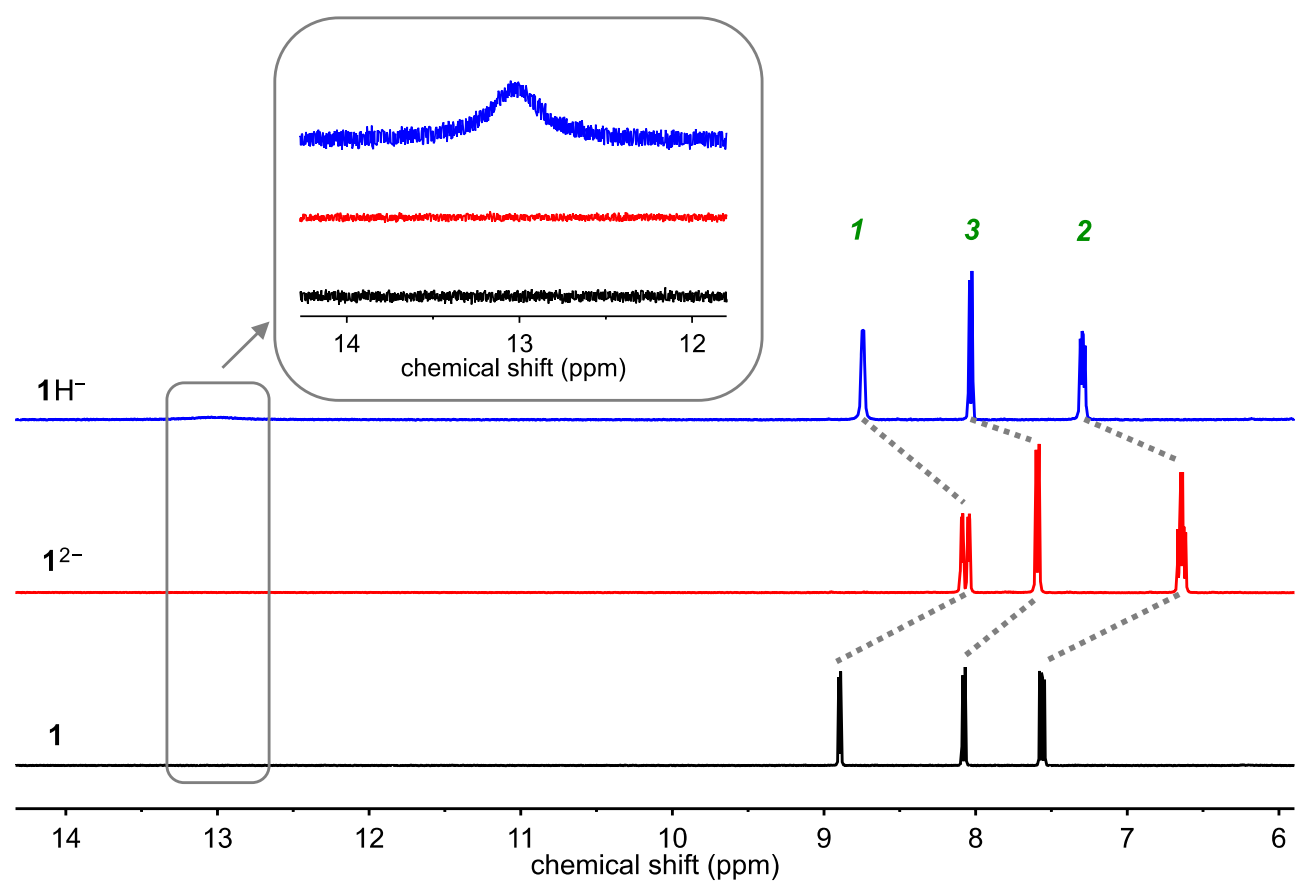

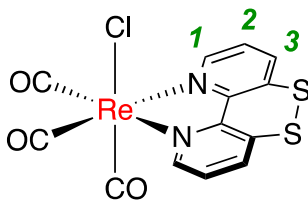

1

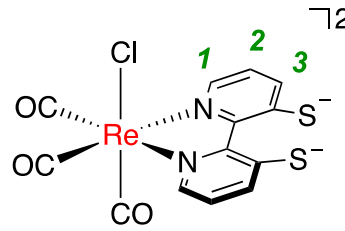

$1^{2-}$

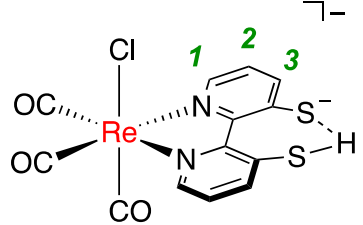

$1 \mathrm{H}^{-}$

Figure S16. ${ }^{1} \mathrm{H} N M R$ spectra $\left(400 \mathrm{MHz}, \mathrm{MeCN}-\mathrm{d}_{3}\right)$ of $\mathbf{1}, \mathbf{1}^{2-}$ and $1 \mathrm{H}^{-}$at $243 \mathrm{~K}$.
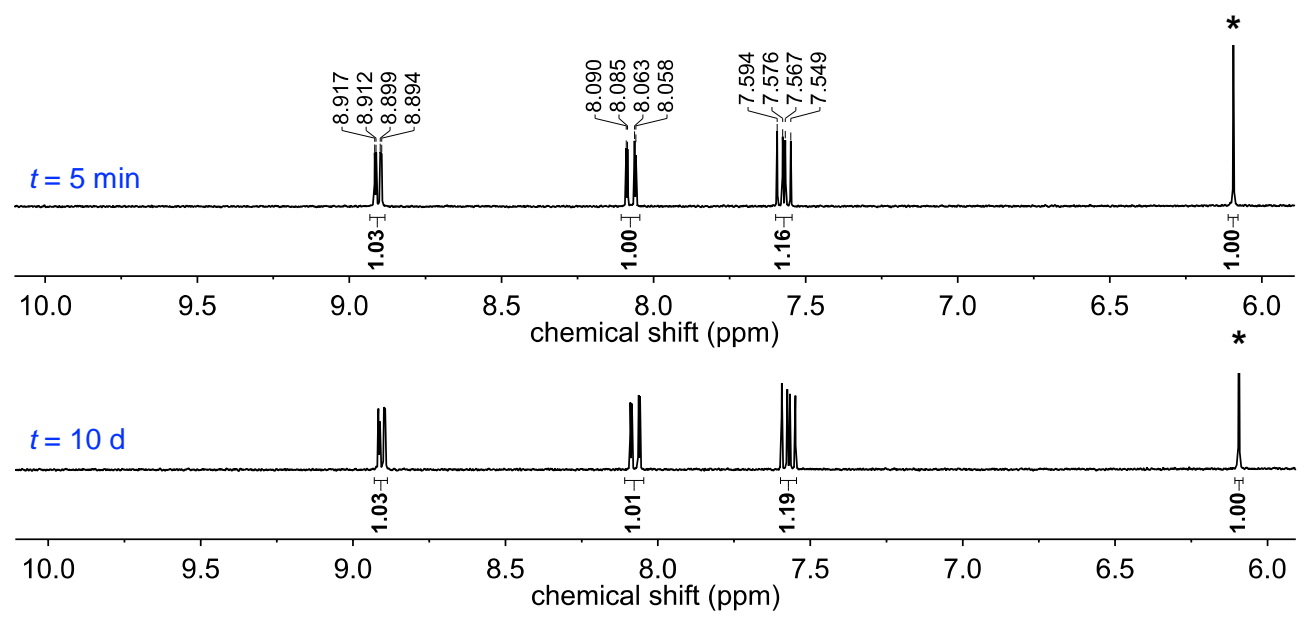

Figure S17. ${ }^{1} \mathrm{H}$ NMR spectra $\left(300 \mathrm{MHz}, \mathrm{MeCN}-\mathrm{d}_{3}\right)$ of monitoring the stability of $1(0.0019 \mathrm{M})$ at $298 \mathrm{~K}$. Peaks marked with asterisk correspond to the internal standard 1,3,5-trimethoxybenzene (0.66 equiv). 
(a)

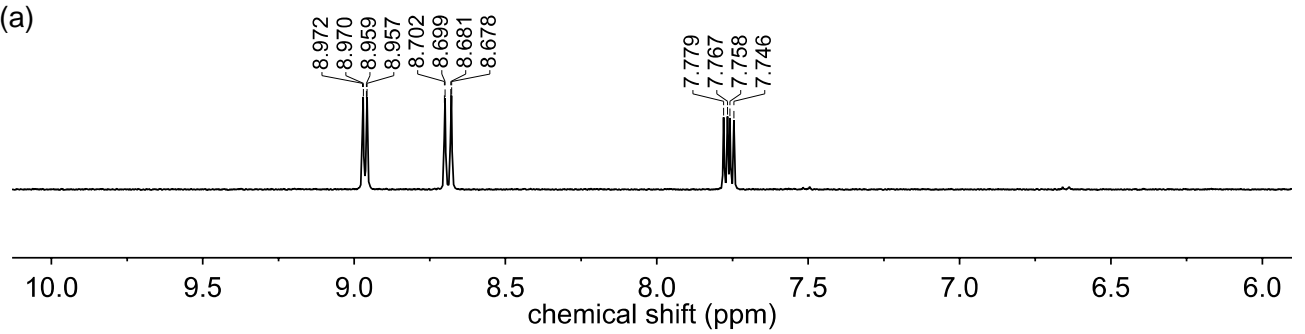

(b)
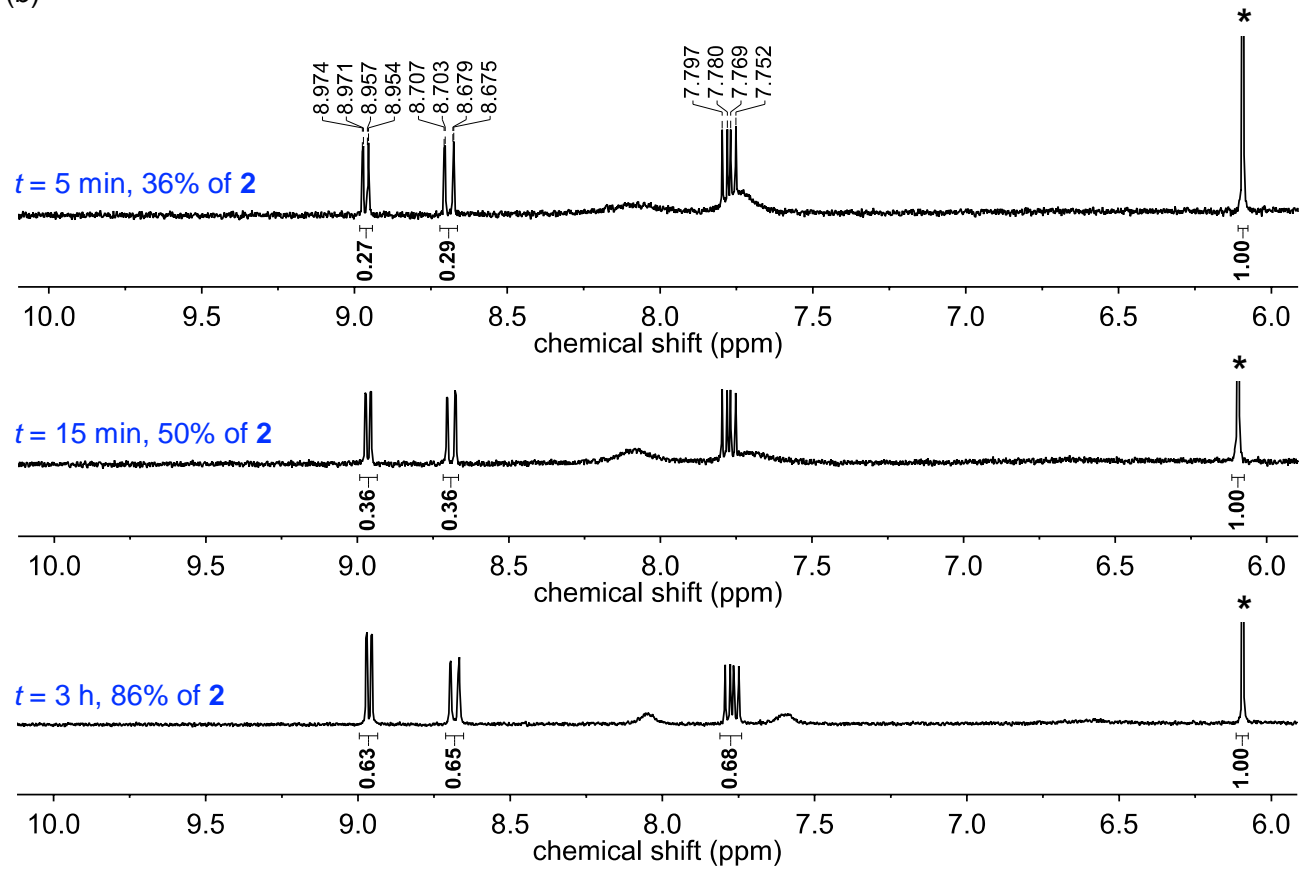

Figure S18. ${ }^{1} \mathrm{H} N \mathrm{NR}$ spectra $\left(300 \mathrm{MHz}, \mathrm{MeCN}-\mathrm{d}_{3}\right)$ of (a) $2(0.0019 \mathrm{M})$ and (b) monitoring the stability of $\mathbf{1}^{2-}(0.0038 \mathrm{M})$ at $298 \mathrm{~K}$. The formation of 2 was determined via integration of the aromatic protons of 2 using 1,3,5-trimethoxybenzene as internal standard (marked with asterisk; 0.5 equiv). 

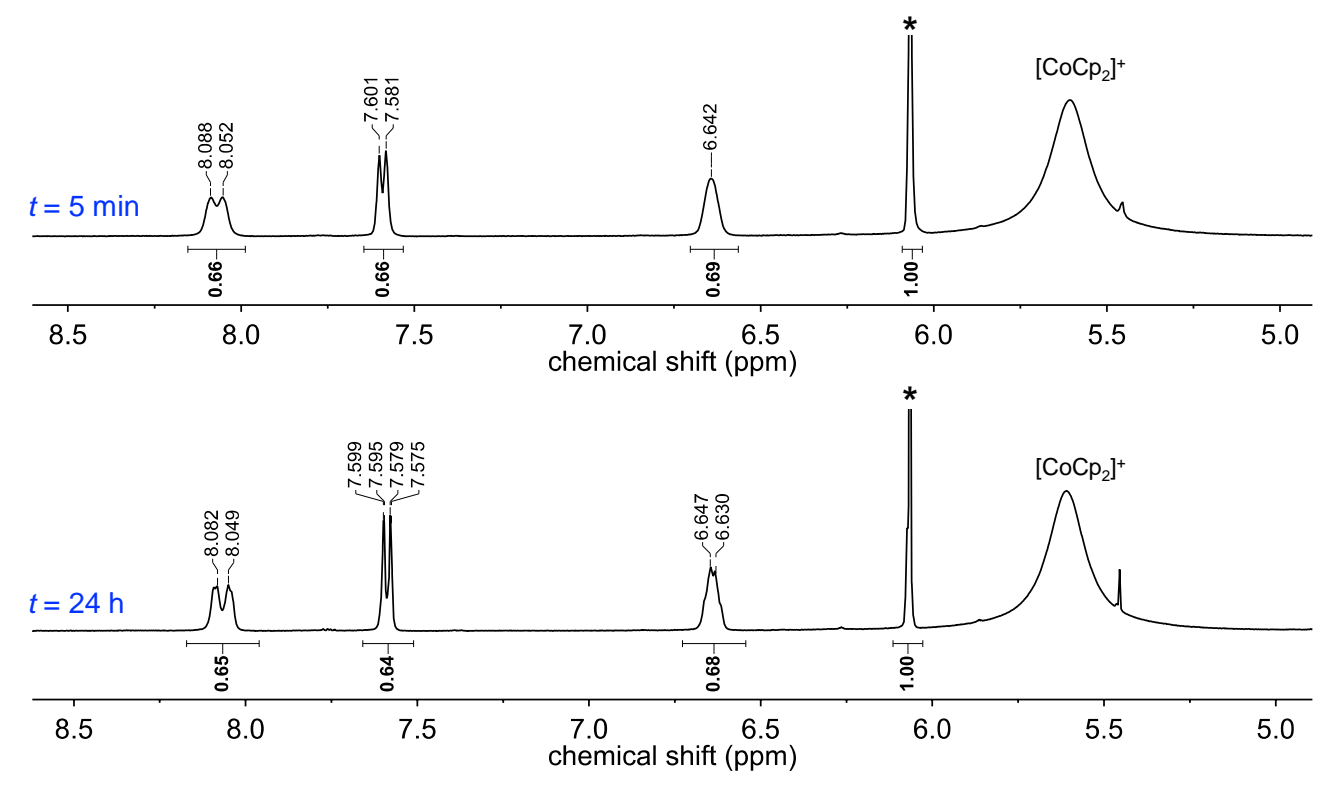

Figure S19. ${ }^{1} \mathrm{H} N \mathrm{NR}$ spectra $\left(400 \mathrm{MHz}, \mathrm{MeCN}-\mathrm{d}_{3}\right)$ of monitoring the stability of $\mathbf{1}^{2-}(0.0038 \mathrm{M})$ at 243 K. Peaks marked with asterisk correspond to the internal standard 1,3,5-trimethoxybenzene (1.0 equiv).
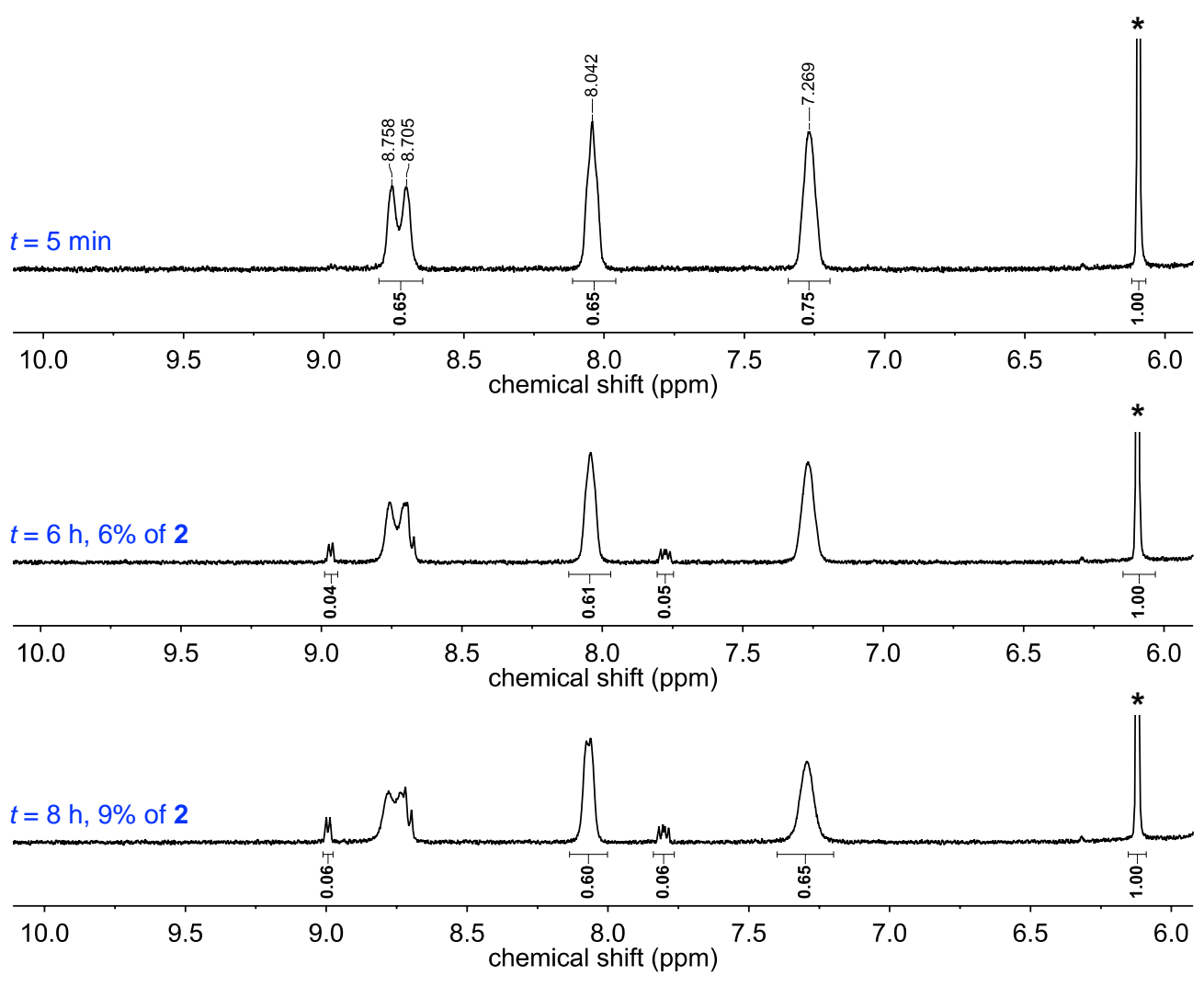

Figure S20. ${ }^{1} \mathrm{H} N \mathrm{MR}$ spectra $\left(400 \mathrm{MHz}, \mathrm{MeCN}-\mathrm{d}_{3}\right)$ of monitoring the stability of $1 \mathrm{H}^{-}(0.0038 \mathrm{M})$ at 298 $K$. The formation of 2 was determined via integration of the aromatic protons of 2 using 1,3,5trimethoxybenzene as internal standard (marked with asterisk; 1.0 equiv). 


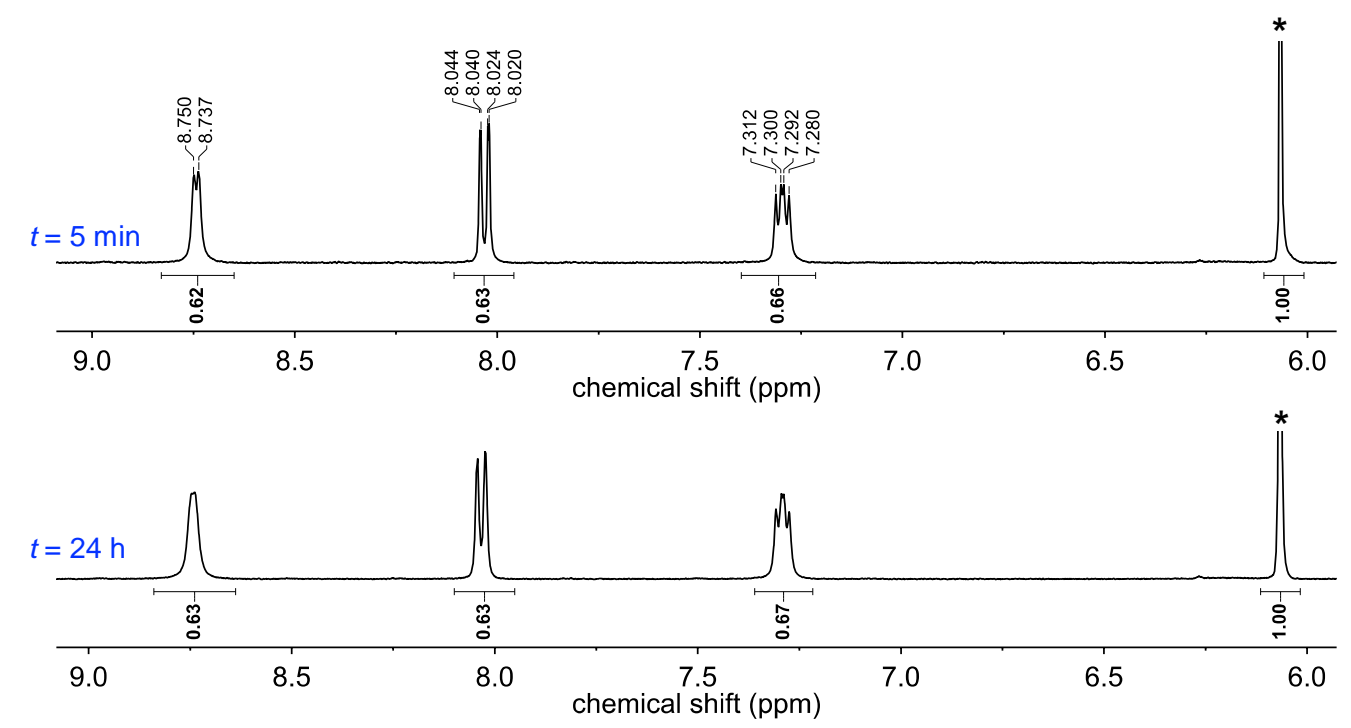

Figure S21. ${ }^{1} \mathrm{H} N \mathrm{MR}$ spectra $\left(400 \mathrm{MHz}, \mathrm{MeCN}-d_{3}\right)$ of monitoring the stability of $\mathbf{1 H}^{-}(0.0038 \mathrm{M})$ at 243 K. Peaks marked with asterisk correspond to the internal standard 1,3,5-trimethoxybenzene (1.0 equiv). 

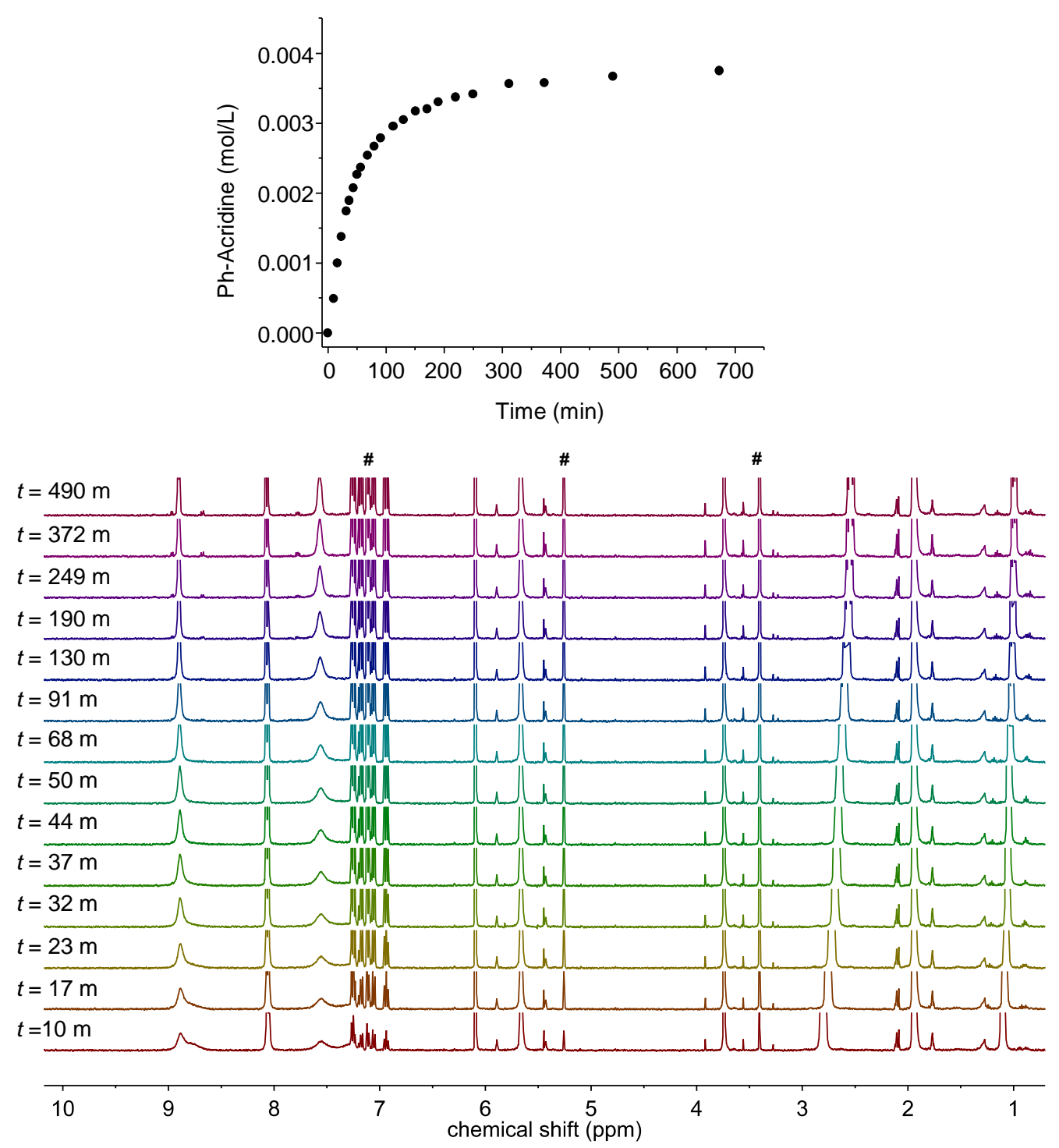

Figure S22. Top: formation of Ph-Acridine over time during the reaction of $\mathrm{IH}^{-}$with $[\mathrm{Ph}-\mathrm{Acr}]\left(\mathrm{ClO}_{4}\right)$ monitored at $298 \mathrm{~K}$. The yield was determined via integration of the methyl group of Ph-Acridine using the aromatic protons of 1,3,5-trimethoxybenzene as internal standard (1.0 equiv). Bottom: selected ${ }^{1} \mathrm{H}$ NMR spectra $\left(400 \mathrm{MHz}, \mathrm{MeCN}-d_{3}\right)$ recorded at different times. Peaks marked with \# correspond to PhAcridine. 


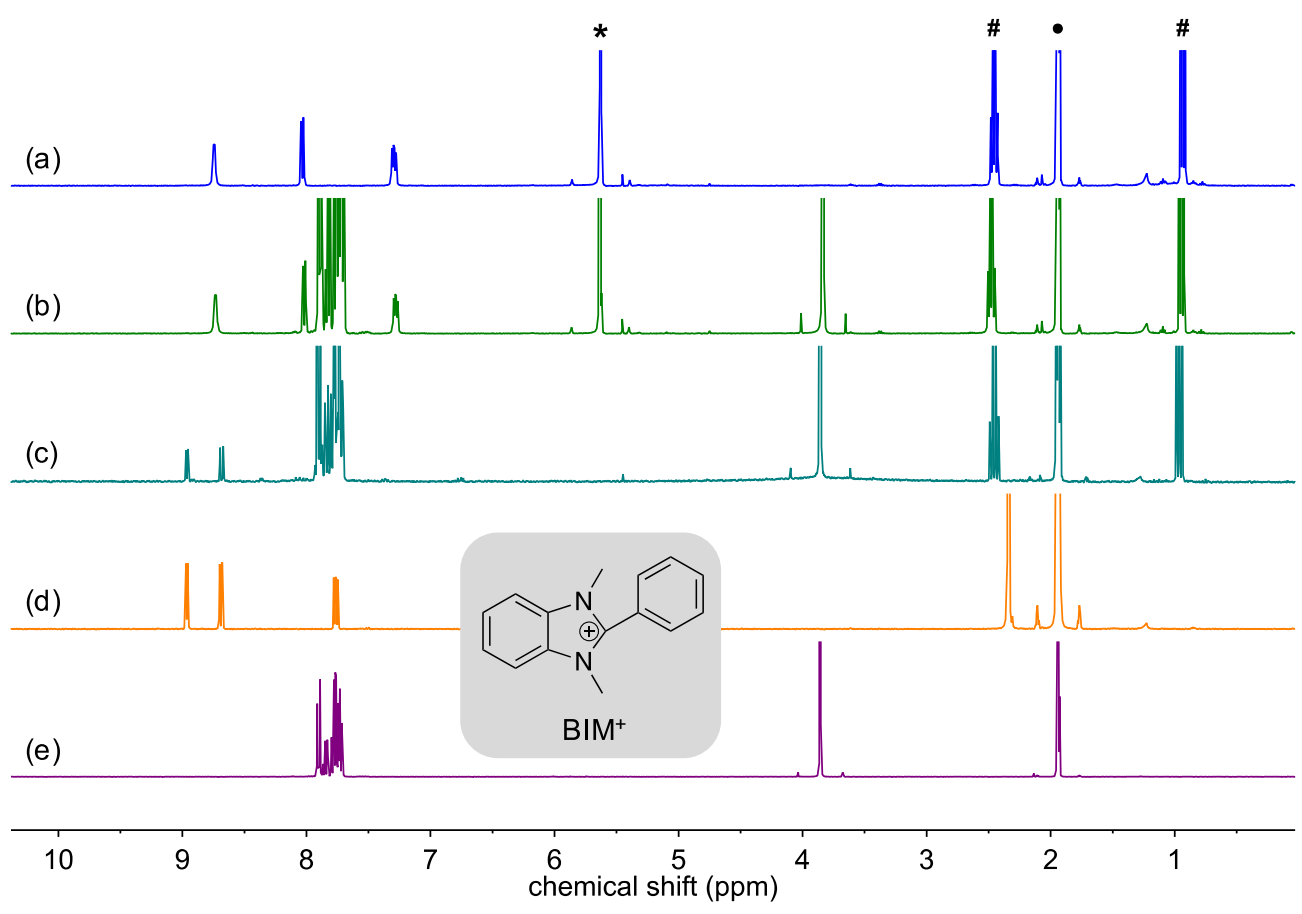

Figure S23. ${ }^{1} \mathrm{H} N M R$ spectra $\left(400 \mathrm{MHz}, \mathrm{MeCN}-\mathrm{d}_{3}\right)$ of (a) $1 \mathrm{H}^{-}$at $243 \mathrm{~K}(\mathrm{~b})$ the reaction of $1 \mathrm{H}^{-}$with $\mathrm{BIM}^{+}$at $243 \mathrm{~K}(\mathrm{c})$ the reaction of $1 \mathrm{H}^{-}$with BIM ${ }^{+}$for additional $30 \mathrm{~h}$ at $298 \mathrm{~K}(\mathrm{~d}) 2$ and (e) $\mathrm{BIM}^{+}$. Peaks marked with \# correspond to $\mathrm{NEt}_{3}$, asterisk corresponds to $\left[\mathrm{CoCp}_{2}\right]^{+}$and black circle corresponds to $\mathrm{MeCN}-d_{3}$. 

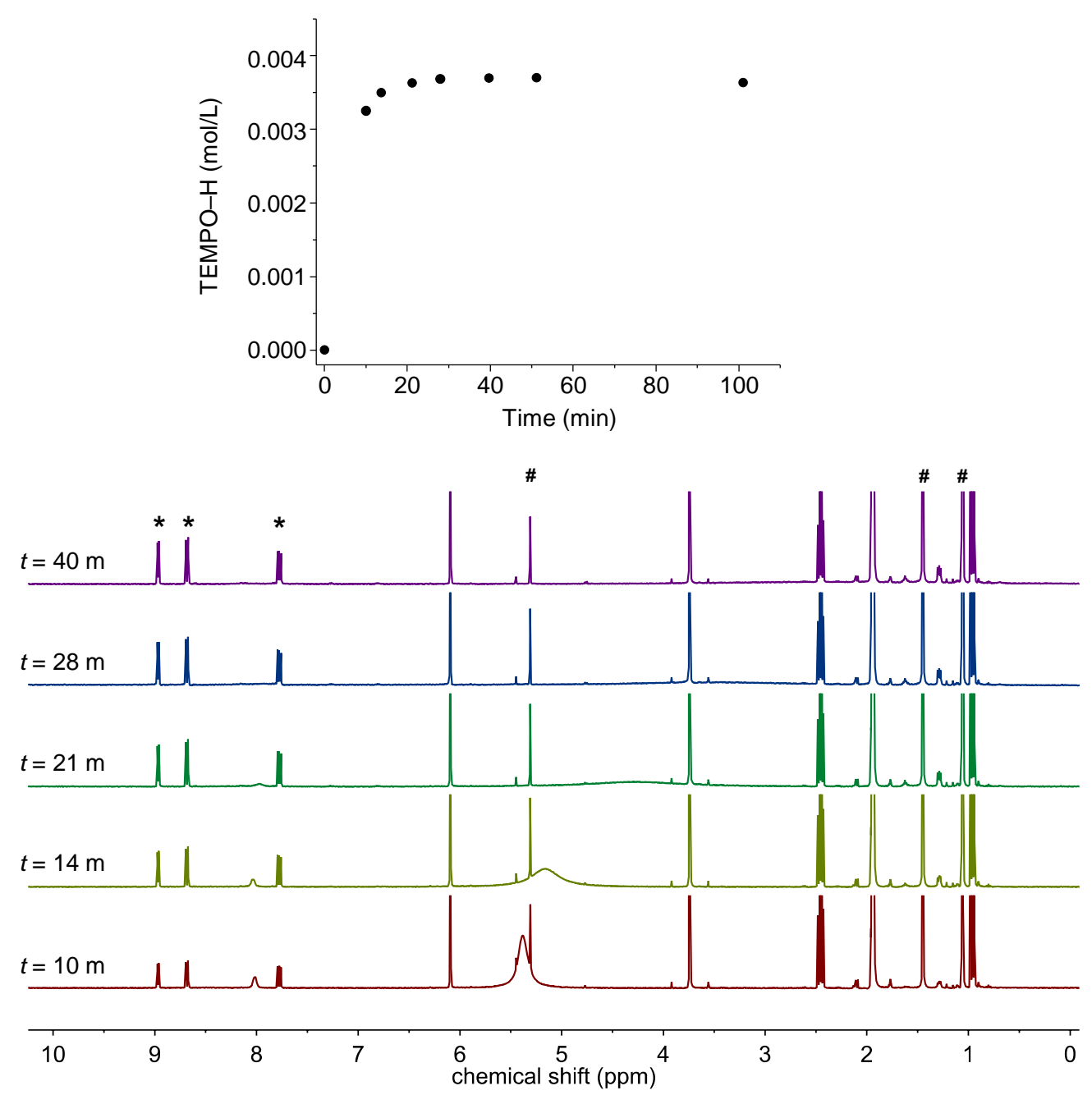

Figure S24. Top: formation of TEMPO-H over time during the reaction of $1 \mathrm{H}^{-}$with TEMPO monitored at $298 \mathrm{~K}$. The yield was determined via integration of the aliphatic protons of TEMPO-H using the aromatic protons of 1,3,5-trimethoxybenzene as internal standard (1.0 equiv). Bottom: selected ${ }^{1} \mathrm{H}$ NMR spectra $\left(400 \mathrm{MHz}, \mathrm{MeCN}-\mathrm{d}_{3}\right)$ recorded at different times. Peaks marked with \# correspond to TEMPO-H and asterisk correspond to 2. 

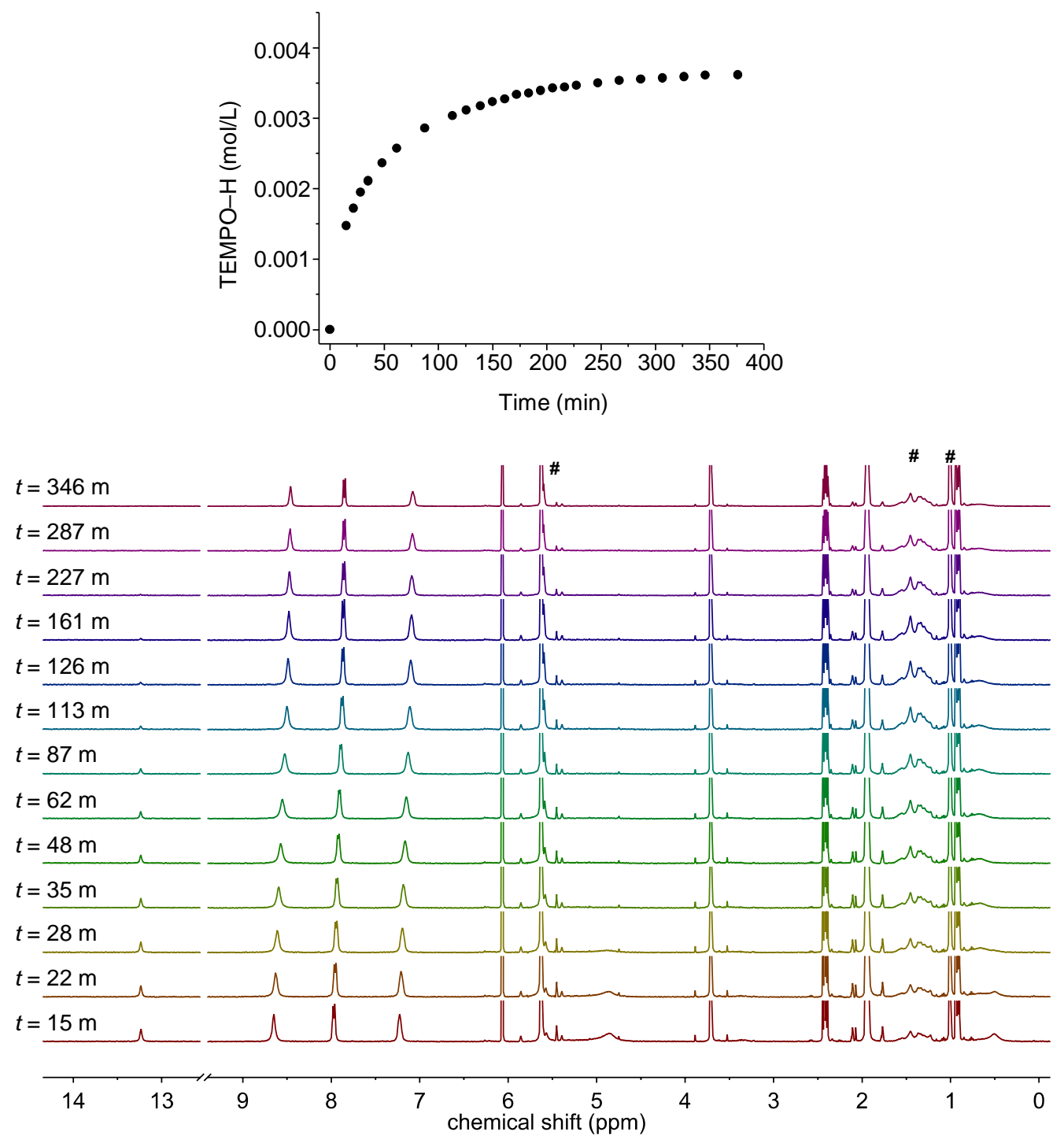

Figure S25. Top: formation of TEMPO-H over time during the reaction of $1 H^{-}$with TEMPO monitored at $243 \mathrm{~K}$. The yield was determined via integration of the methyl group of TEMPO-H using 1,3,5-trimethoxybenzene as internal standard (1.0 equiv). Bottom: selected ${ }^{1} \mathrm{H} N \mathrm{NR}$ spectra $(400 \mathrm{MHz}$, $\left.\mathrm{MeCN}-\mathrm{d}_{3}\right)$ recorded at different times. Peaks marked with \# correspond to TEMPO-H. 


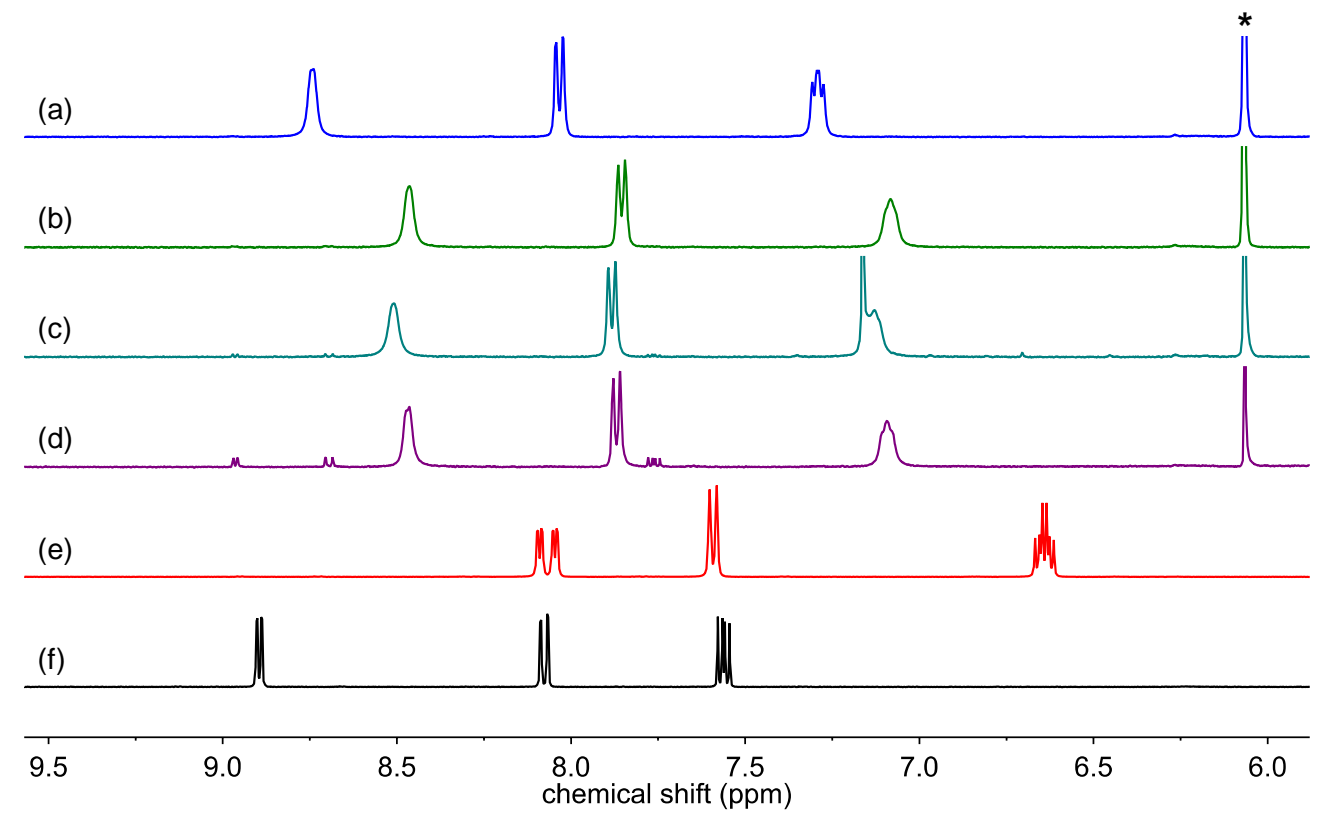

Figure S26. ${ }^{1} \mathrm{H} N \mathrm{NR}$ spectra at $243 \mathrm{~K}\left(400 \mathrm{MHz}, \mathrm{MeCN}-\mathrm{d}_{3}\right)$ of $\left(\right.$ a) $1 \mathrm{H}^{-}$(b) reaction mixture of $1 \mathrm{H}^{-}$with $T_{E M P O}{ }^{(}(c)$ reaction mixture of $\mathbf{1 H}^{-}$with 2,4,6-TTBP ${ }^{\bullet}$ and $(d) 1: 1$ mixture of $\mathbf{1}$ and $\mathbf{1}^{2-}(e) \mathbf{1}^{2-}$ and $(f)$ 1. Peak marked with asterisk correspond to the internal standard 1,3,5-trimethoxybenzene. 

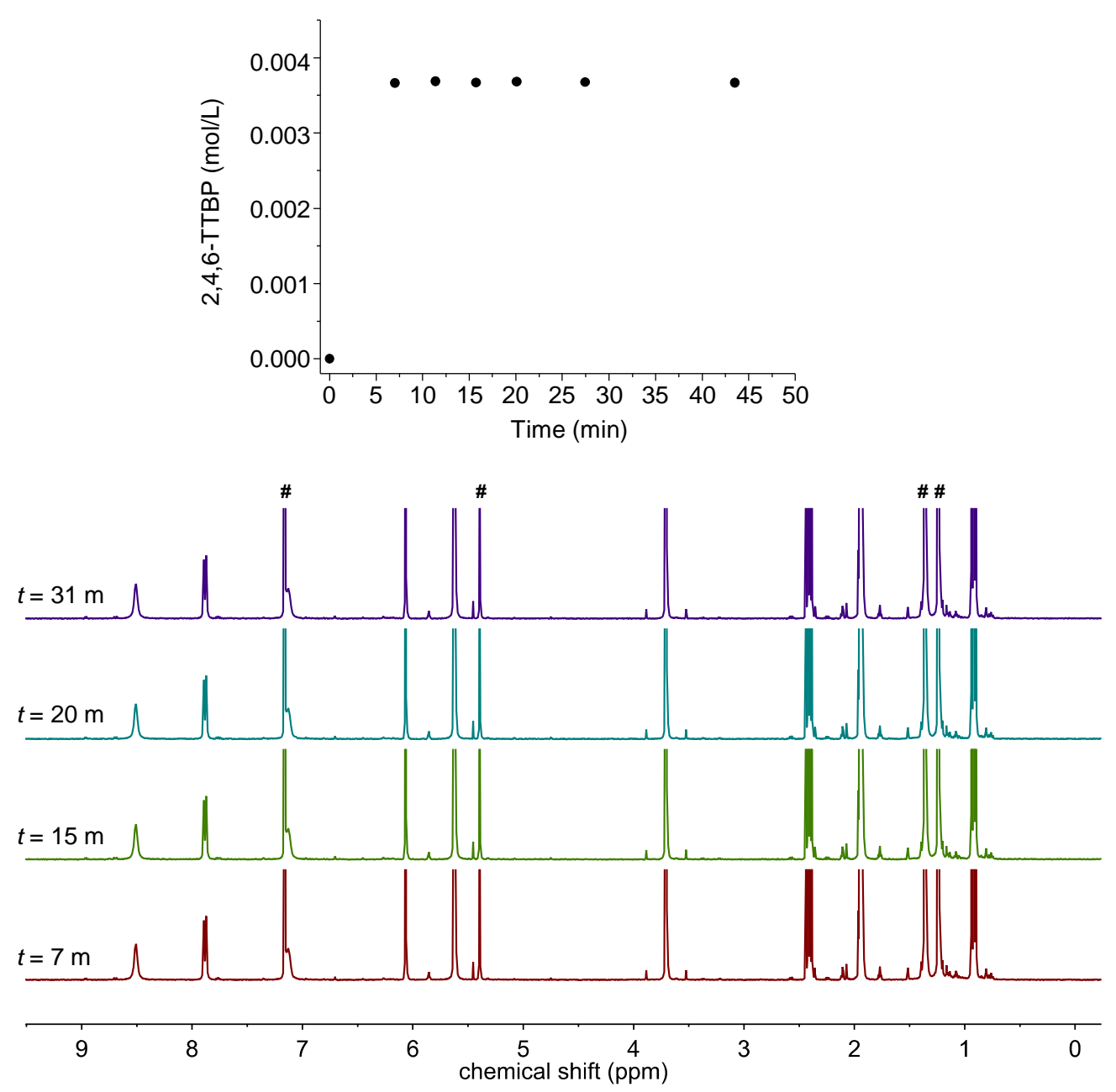

Figure S27. Top: formation of 2,4,6-TTBP over time during the reaction of $\mathbf{1} H^{-}$with 2,4,6-TTBP• monitored at $243 \mathrm{~K}$. The yield was determined via integration of the ortho-methyl groups of 2,4,6-TTBP using the methyl group of 1,3,5-trimethoxybenzene as internal standard (1.0 equiv). Bottom: selected ${ }^{1} \mathrm{H} N \mathrm{NR}$ spectra $\left(400 \mathrm{MHz}, \mathrm{MeCN}-d_{3}\right)$ recorded at different times. Peaks marked with \# correspond to 2,4,6-TTBP. 


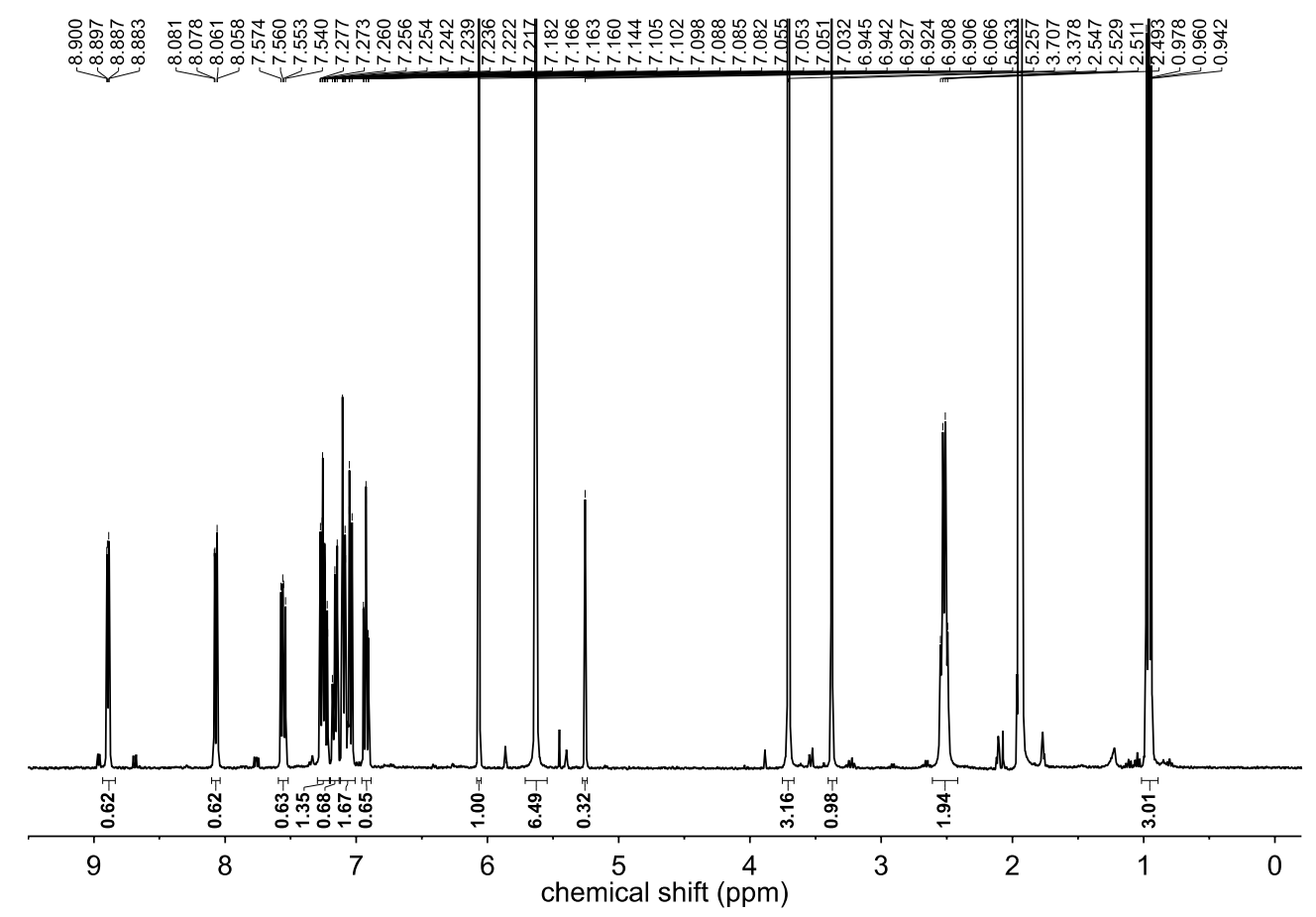

Figure S28. ${ }^{1} \mathrm{H} N \mathrm{NR}$ spectrum $\left(400 \mathrm{MHz}, \mathrm{MeCN}-\mathrm{d}_{3}\right)$ recorded at $243 \mathrm{~K}$ of the reaction of $1 \mathrm{H}^{-}$with $[\mathrm{Ph}$ Acr $]\left(\mathrm{ClO}_{4}\right)$. Assignment: Ph-AcrH: $87.27-7.03(\mathrm{~m}, 11 \mathrm{H}, \mathrm{ar}), 6.93(\mathrm{td}, 2 \mathrm{H}, \mathrm{J}=7.2,0.8 \mathrm{~Hz}$, ar $), 5.26(\mathrm{~s}$, $3 \mathrm{H}, \mathrm{CH}$ ), $3.38\left(\mathrm{~s}, 3 \mathrm{H}, \mathrm{CH}_{3}\right) ; 1: \delta 8.89(\mathrm{dd}, 2 \mathrm{H}, \mathrm{J}=5.6,1.6 \mathrm{~Hz}), 8.07(\mathrm{dd}, 2 \mathrm{H}, \mathrm{J}=8.0,1.2 \mathrm{~Hz}), 7.56(\mathrm{dd}$, $2 \mathrm{H}, \mathrm{J}=8.0,5.2 \mathrm{~Hz}$ ); 1,3,5-trimethoxybenzene: $\delta 6.07(\mathrm{~s}, 3 \mathrm{H}, \mathrm{ar}), 3.71\left(\mathrm{~s}, 9 \mathrm{H}, \mathrm{CH}_{3}\right) ;\left[\mathrm{CoCp}_{2}\right]^{+}: \delta 5.63$ (s, 20H, Cp); $\mathrm{NEt}_{3}: \delta 2.52$ (q, $\left.6 \mathrm{H}, \mathrm{J}=7.2 \mathrm{~Hz}, \mathrm{CH}_{2}\right) ; 0.96\left(t, 9 \mathrm{H}, \mathrm{J}=7.2 \mathrm{~Hz}, \mathrm{CH}_{3}\right.$ ). 


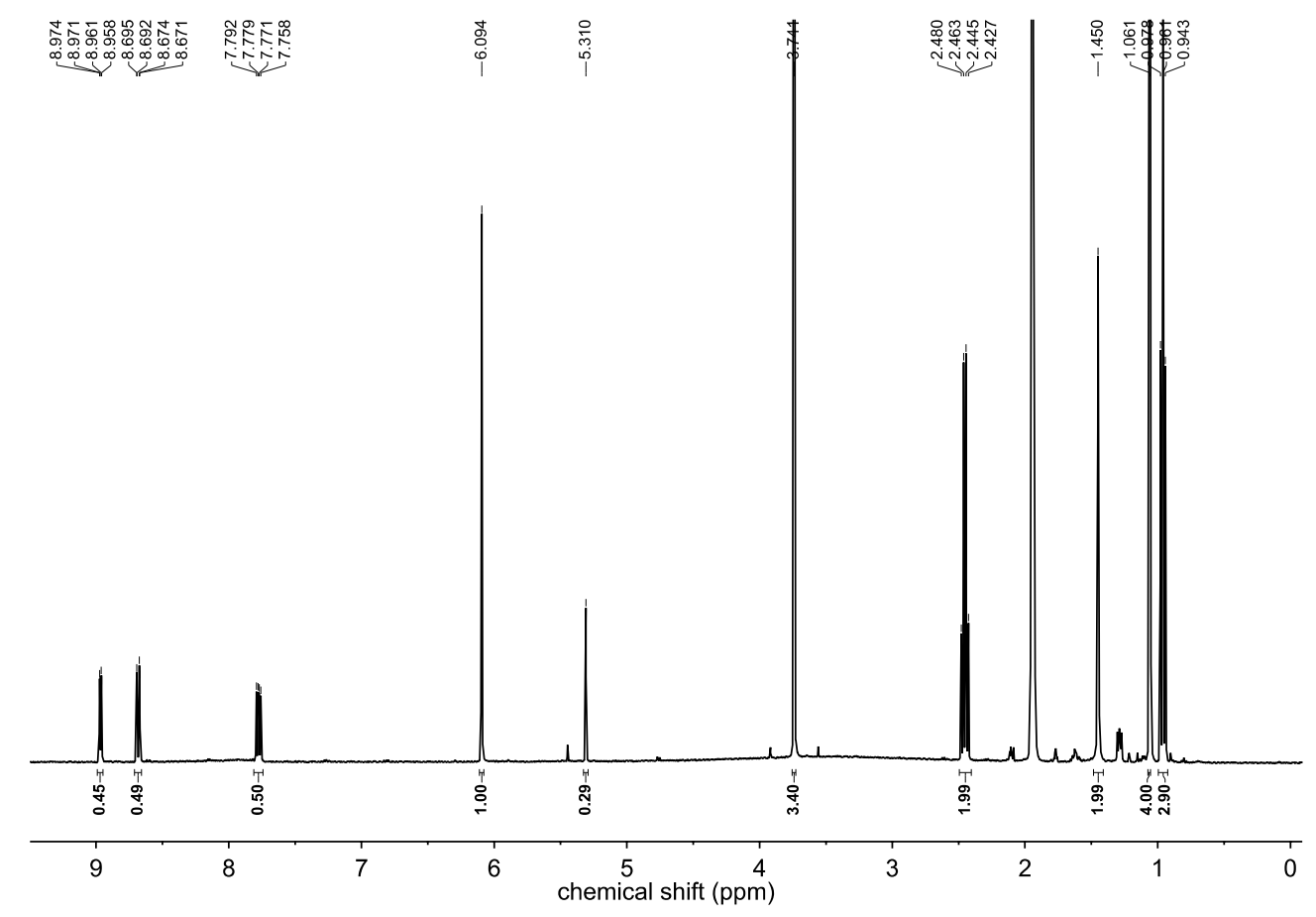

Figure S29. ${ }^{1} \mathrm{H} N M R$ spectrum $\left(400 \mathrm{MHz}, \mathrm{MeCN}-d_{3}\right)$ recorded at $298 \mathrm{~K}$ of the reaction of $1 \mathrm{H}^{-}$with TEMPO ${ }^{\bullet}$. Assignment: TEMPO-H ${ }^{26}: \delta 5.31(\mathrm{~s}, \mathrm{lH}, \mathrm{OH}), 1.45\left(\mathrm{~s}, 6 \mathrm{H}, \mathrm{CH}_{2}\right), 1.06\left(\mathrm{~s}, 12 \mathrm{H}, \mathrm{CH}_{3}\right) ; 2: \delta$ $8.97(d d, 2 H, J=5.2,1.2 \mathrm{~Hz}), 8.68(d d, 2 H, J=8.4,1.2 \mathrm{~Hz}), 7.78(d d, 2 H, J=8.4,5.2 \mathrm{~Hz}) ; \mathbf{1 , 3 , 5}-$ trimethoxybenzene: $\delta 6.09(\mathrm{~s}, 3 \mathrm{H}, \mathrm{ar}), 3.74\left(\mathrm{~s}, 9 \mathrm{H}, \mathrm{CH}_{3}\right) ; \mathrm{NEt}_{3}: \delta 2.45\left(q, 6 \mathrm{H}, \mathrm{J}=7.2 \mathrm{~Hz}, \mathrm{CH}_{2}\right) ; 0.96$ $\left(t, 9 \mathrm{H}, \mathrm{J}=7.2 \mathrm{~Hz}, \mathrm{CH}_{3}\right)$. 


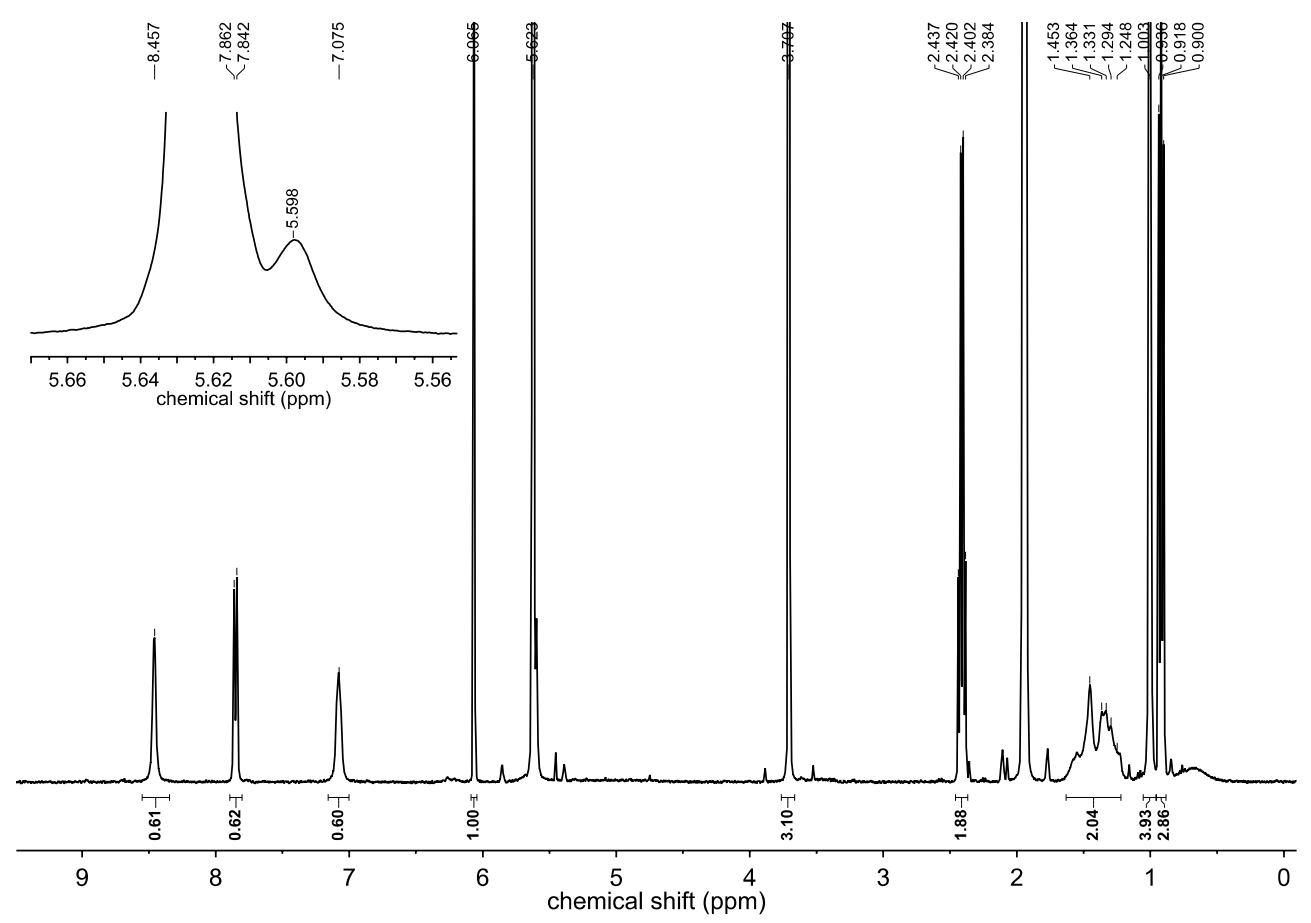

Figure S30. ${ }^{1} \mathrm{H} N M R$ spectrum $\left(400 \mathrm{MHz}, \mathrm{MeCN}-d_{3}\right)$ recorded at $243 \mathrm{~K}$ of the reaction of $1 \mathrm{H}^{-}$with TEMPO ${ }^{\bullet}$. Assignment: TEMPO-H: $\delta 5.60(\mathrm{~s}, \mathrm{lH}, \mathrm{OH}), 1.25 \sim 1.55\left(\mathrm{~m}, 6 \mathrm{H}, \mathrm{CH}_{2}\right), 1.00\left(\mathrm{~s}, 12 \mathrm{H}, \mathrm{CH}_{3}\right)$; $1 / \mathbf{1}^{2-}: \delta 8.46(\mathrm{br}, 2 \mathrm{H}), 7.85(\mathrm{~d}, 2 \mathrm{H}, \mathrm{J}=8), 7.08(\mathrm{br}, 2 \mathrm{H})$; 1,3,5-trimethoxybenzene: $\delta 6.07(\mathrm{~s}, 3 \mathrm{H}$, ar), 3.71(s, 9H, CH 3$)\left[\mathrm{CoCp}_{2}\right]^{+}: \delta 5.62(\mathrm{~s}, 20 \mathrm{H}, \mathrm{Cp}) ; \mathrm{NEt}_{3}: \delta 2.41\left(q, 6 \mathrm{H}, \mathrm{J}=7.2 \mathrm{~Hz}, \mathrm{CH}_{2}\right) ; 0.92(t, 9 \mathrm{H}, \mathrm{J}=$ $\left.7.2 \mathrm{~Hz}, \mathrm{CH}_{3}\right)$. 


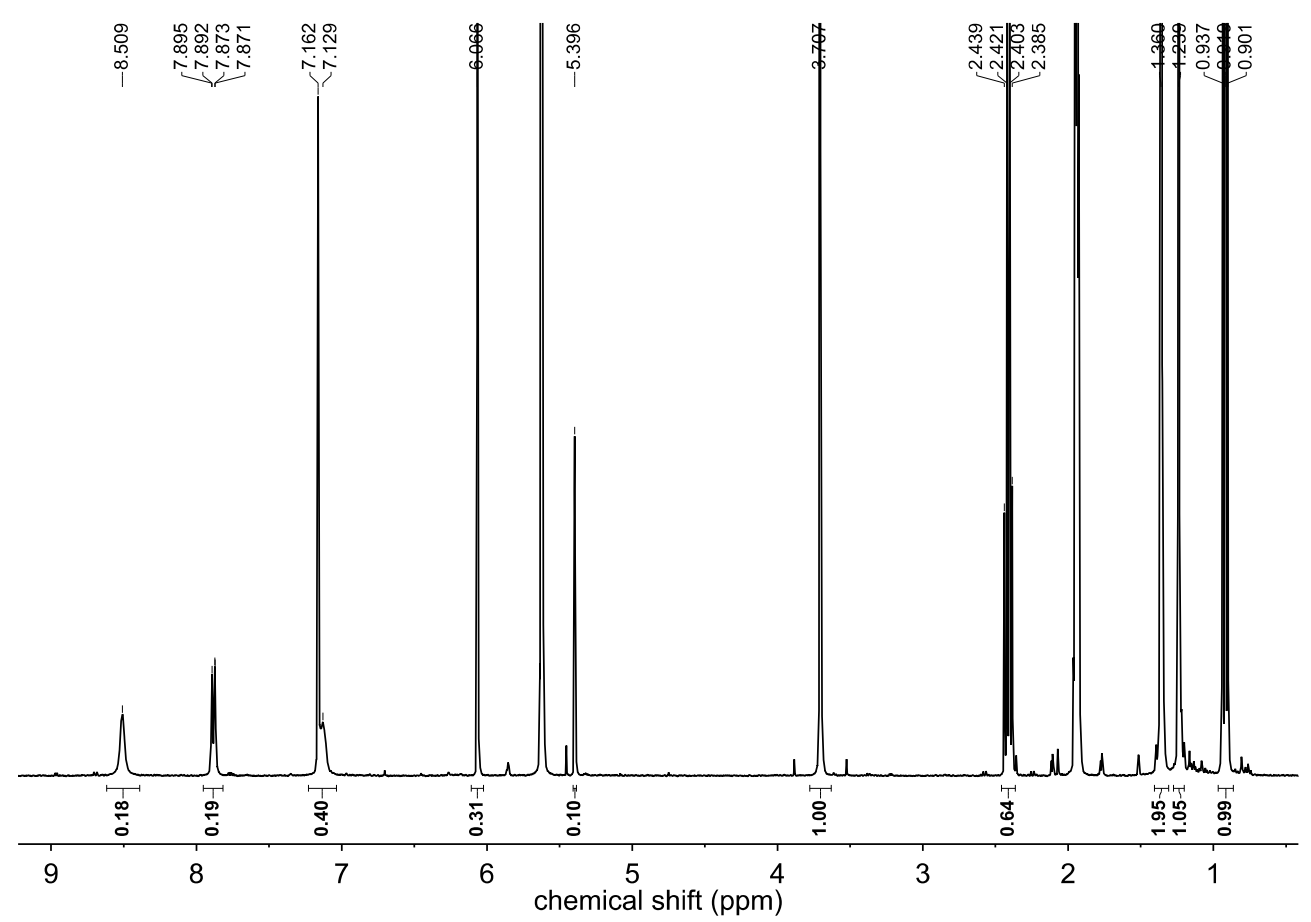

Figure S31. ${ }^{1} \mathrm{H} N \mathrm{NR}$ spectrum $\left(400 \mathrm{MHz}, \mathrm{MeCN}-\mathrm{d}_{3}\right)$ at $243 \mathrm{~K}$ of the reaction of $1 \mathrm{H}^{-}$with 2,4,6-TTBP . Assignment: 2,4,6-TTBP: $\delta 7.16(\mathrm{~s}, 2 \mathrm{H}, \mathrm{ar}), 5.40(\mathrm{~s}, 1 \mathrm{H}, \mathrm{OH}), 1.36\left(\mathrm{~s}, 18 \mathrm{H}, \mathrm{o}^{\mathrm{t}} \mathrm{Bu}\right), 1.24\left(\mathrm{~s}, 9 \mathrm{H}, \mathrm{p}-^{t} \mathrm{Bu}\right)$; 1/1 ${ }^{2-}: \delta 8.51(\mathrm{br}, 2 \mathrm{H}), 7.88(\mathrm{dd}, 2 \mathrm{H}, \mathrm{J}=8.4,0.8 \mathrm{~Hz}), 7.13(\mathrm{br}, 2 \mathrm{H})$; 1,3,5-trimethoxybenzene: $\delta 6.07(\mathrm{~s}$, $3 \mathrm{H}, \mathrm{ar}), 3.71\left(\mathrm{~s}, 9 \mathrm{H}, \mathrm{CH}_{3}\right) ;\left[\mathrm{CoCp}_{2}\right]^{+}: \delta 5.63(\mathrm{~s}, 2 \mathrm{H}, \mathrm{Cp}) ; \mathrm{NEt}_{3}: \delta 2.41\left(q, 6 \mathrm{H}, \mathrm{J}=7.2 \mathrm{~Hz}, \mathrm{CH}_{2}\right) ; 0.92$ $\left(t, 9 \mathrm{H}, \mathrm{J}=7.2 \mathrm{~Hz}, \mathrm{CH}_{3}\right)$. 
5.3.2. Pure Compounds

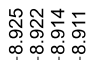

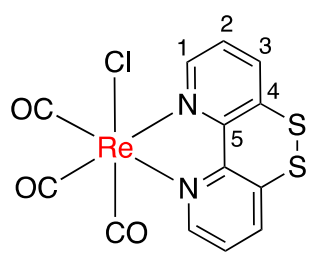

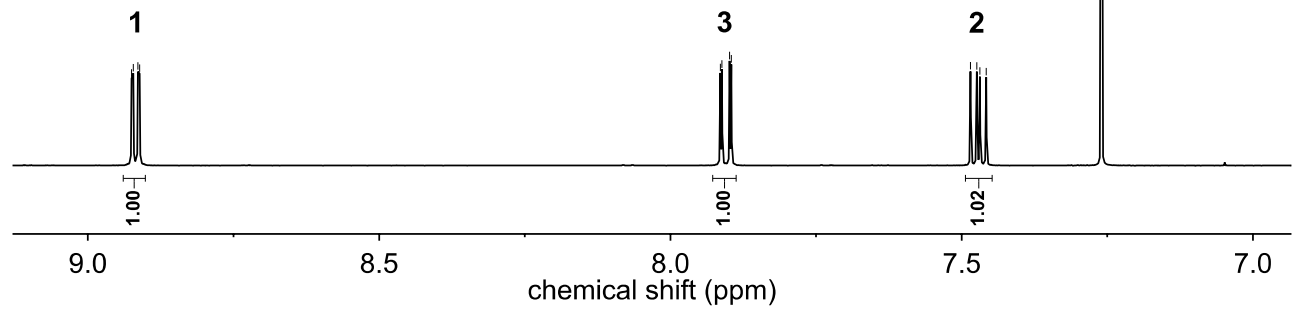

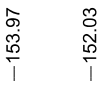

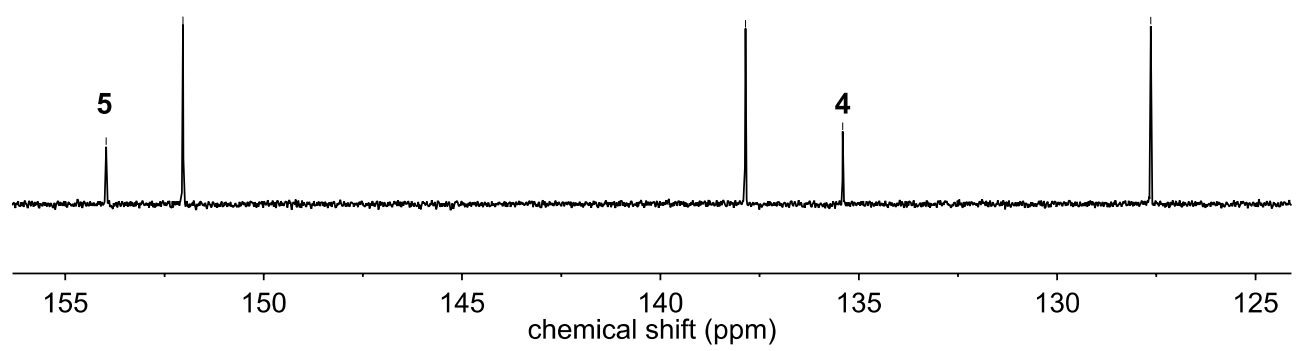

Figure S32. ${ }^{1} \mathrm{H}$ (top) and ${ }^{13} \mathrm{C}\left\{{ }^{1} \mathrm{H}\right\}$ (bottom) NMR spectra of 1 in $\mathrm{CDCl}_{3}$ at $298 \mathrm{~K}$. 


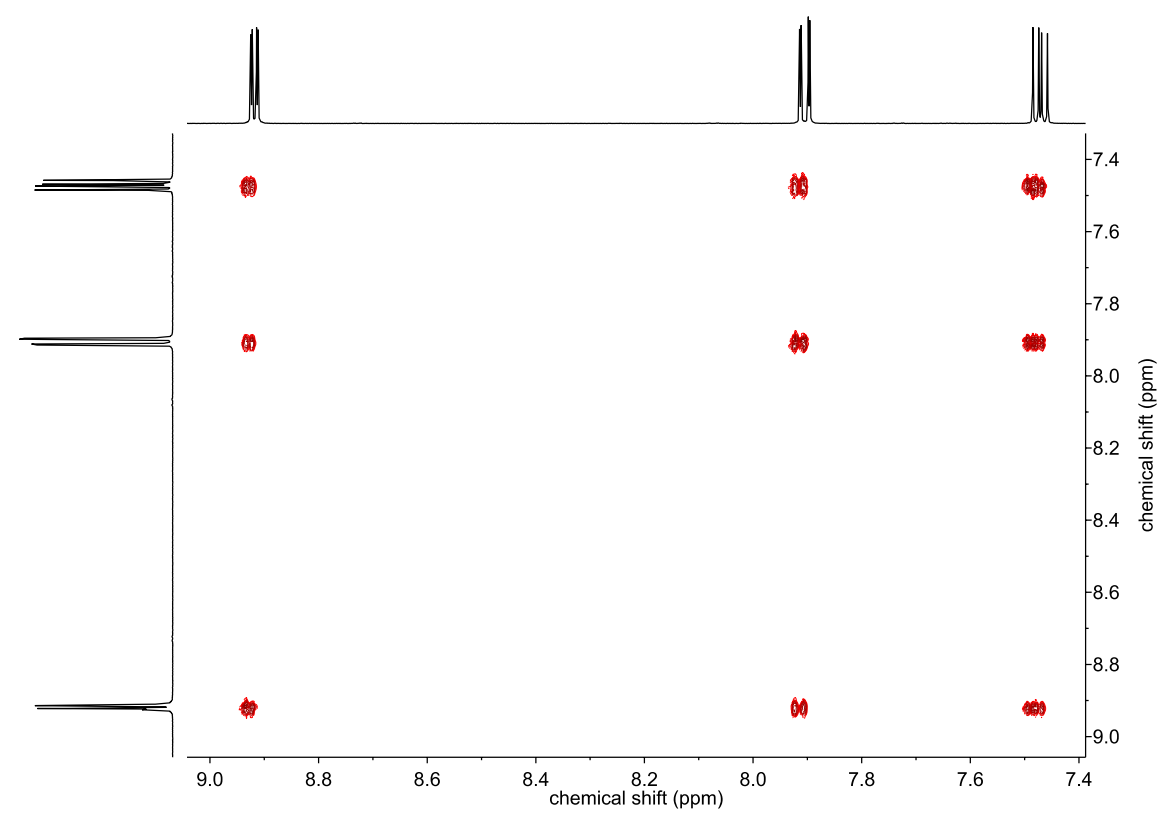

Figure S33. ${ }^{1} \mathrm{H}^{-1} \mathrm{H}$ COSY NMR spectrum of 1 in $\mathrm{CDCl}_{3}$ at $298 \mathrm{~K}$.

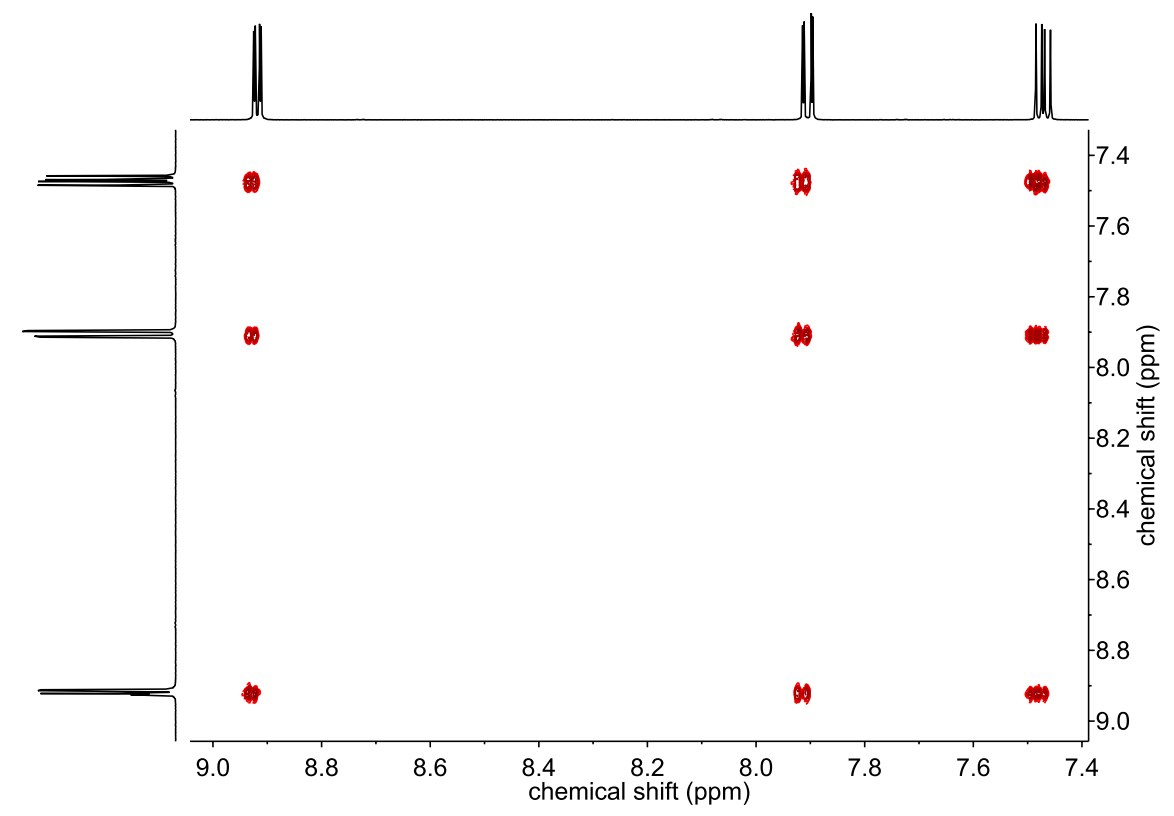

Figure S34. ${ }^{1} \mathrm{H}^{-13} \mathrm{C}$ HSQC NMR spectrum of 1 in $\mathrm{CDCl}_{3}$ at $298 \mathrm{~K}$. 


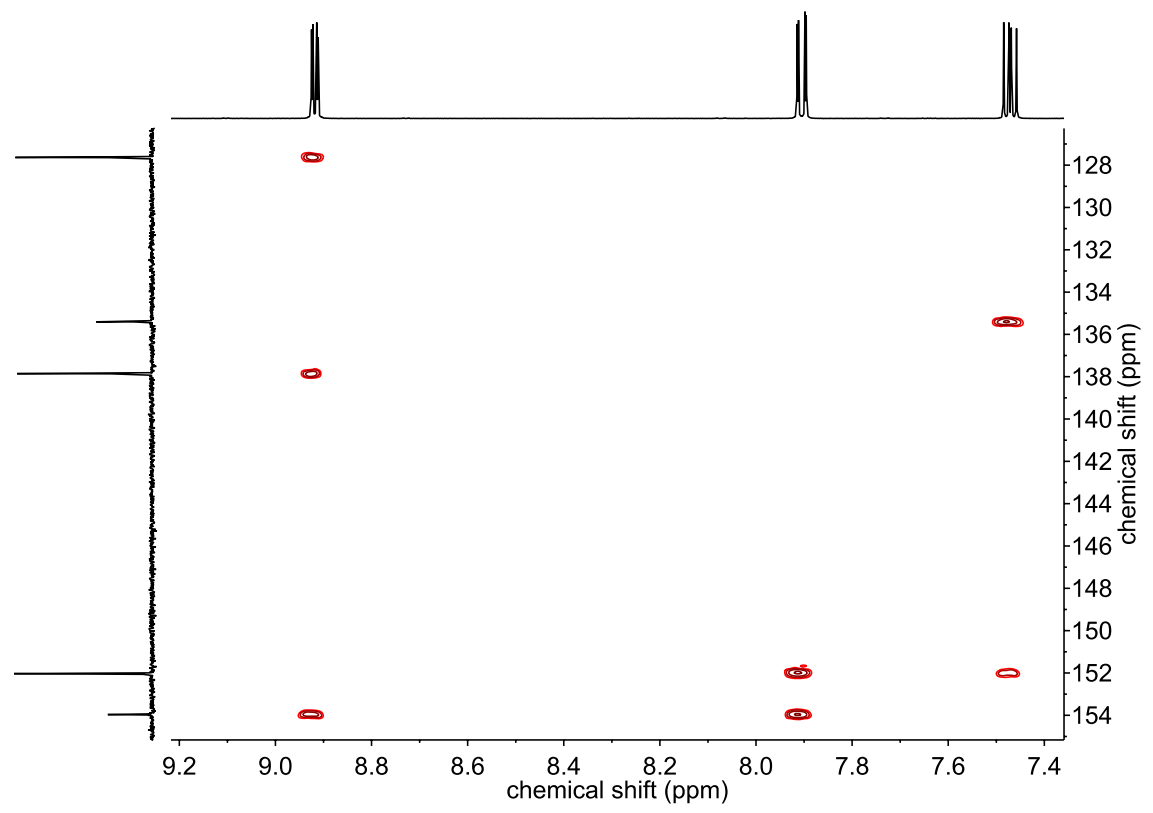

Figure S35. ${ }^{1} \mathrm{H}^{-13} \mathrm{C} \mathrm{HMBC} \mathrm{NMR} \mathrm{spectrum} \mathrm{of} 1$ in $\mathrm{CDCl}_{3}$ at $298 \mathrm{~K}$. 


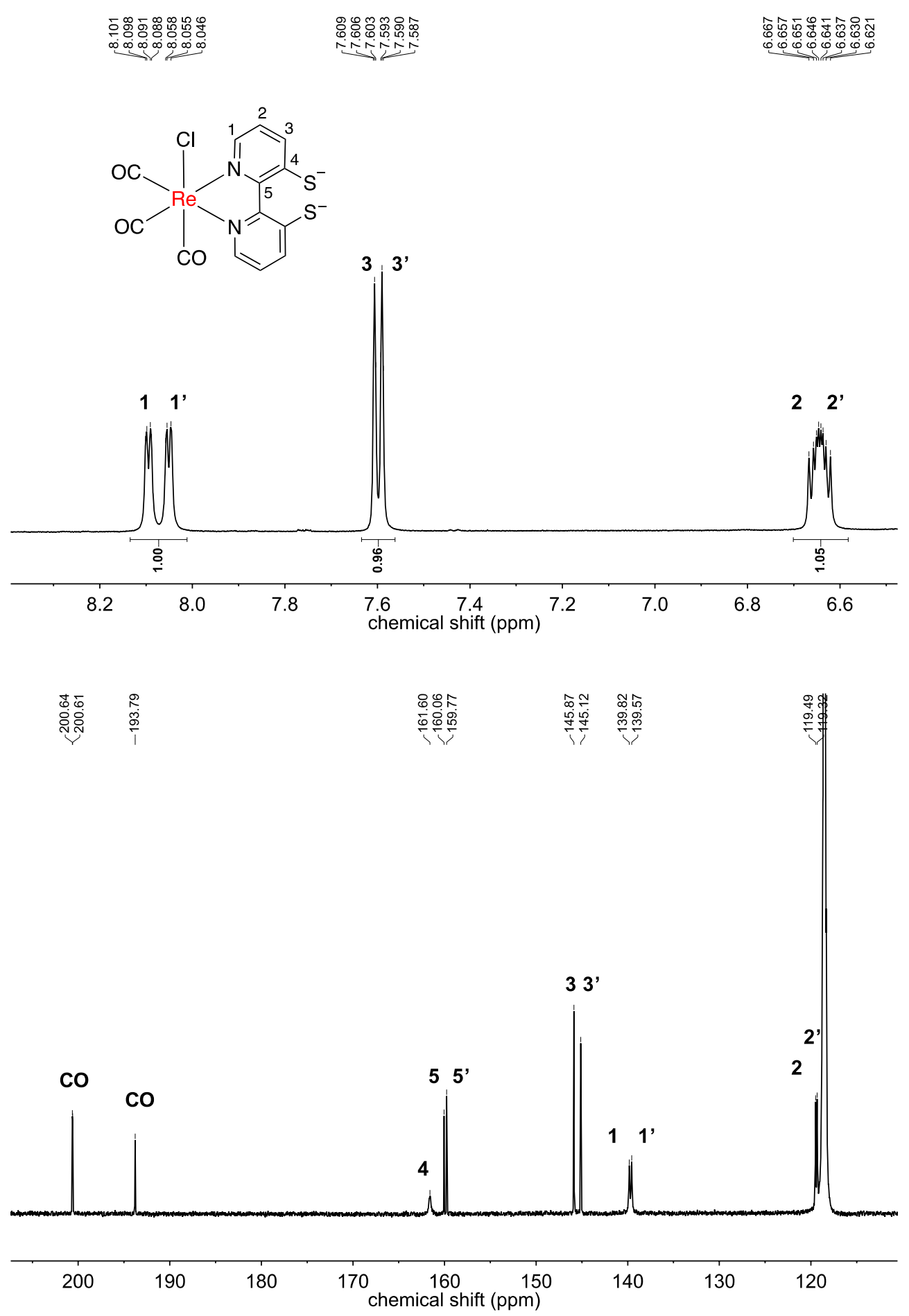

Figure S36. ${ }^{1} \mathrm{H}$ (top) and ${ }^{13} \mathrm{C}\left\{{ }^{1} \mathrm{H}\right\}$ (bottom) NMR spectra of $\mathbf{1}^{2-}$ in MeCN-d $d_{3}$ at $243 \mathrm{~K}$. 


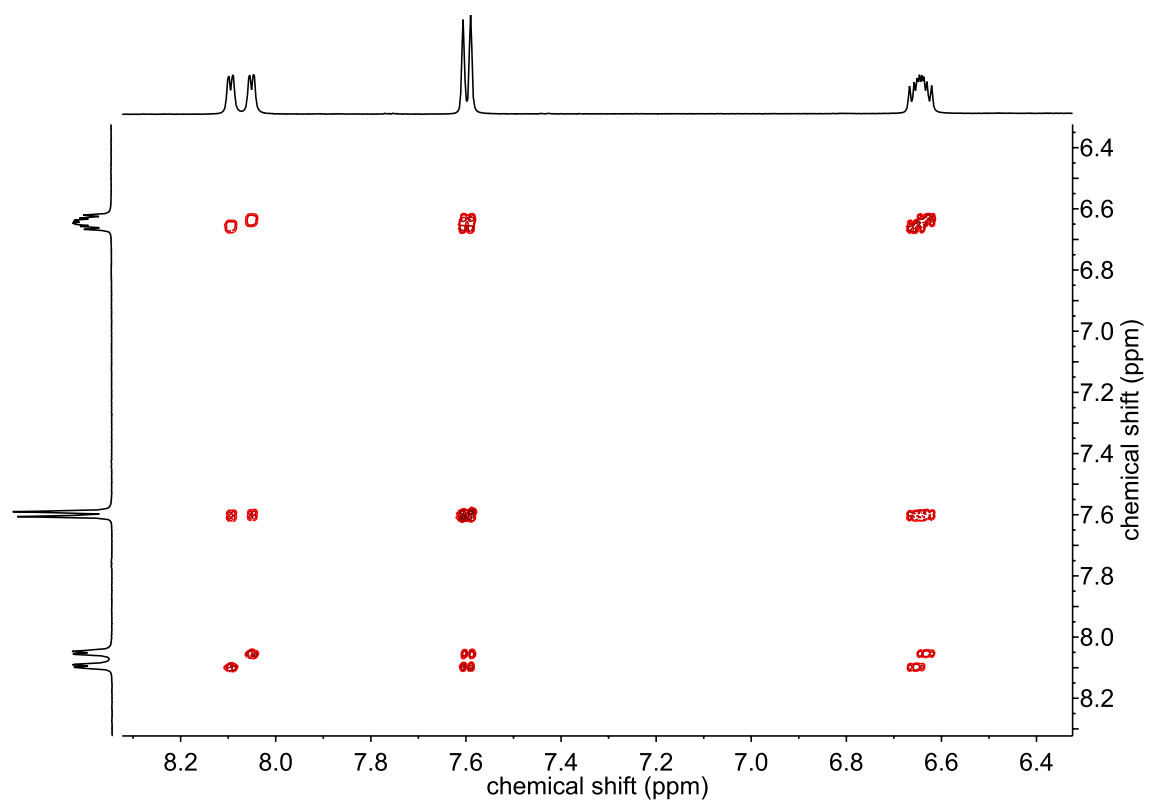

Figure S37. ${ }^{1} \mathrm{H}^{-1} \mathrm{H}$ COSY NMR spectrum of $\mathbf{1}^{2-}$ in MeCN-d at $243 \mathrm{~K}$.

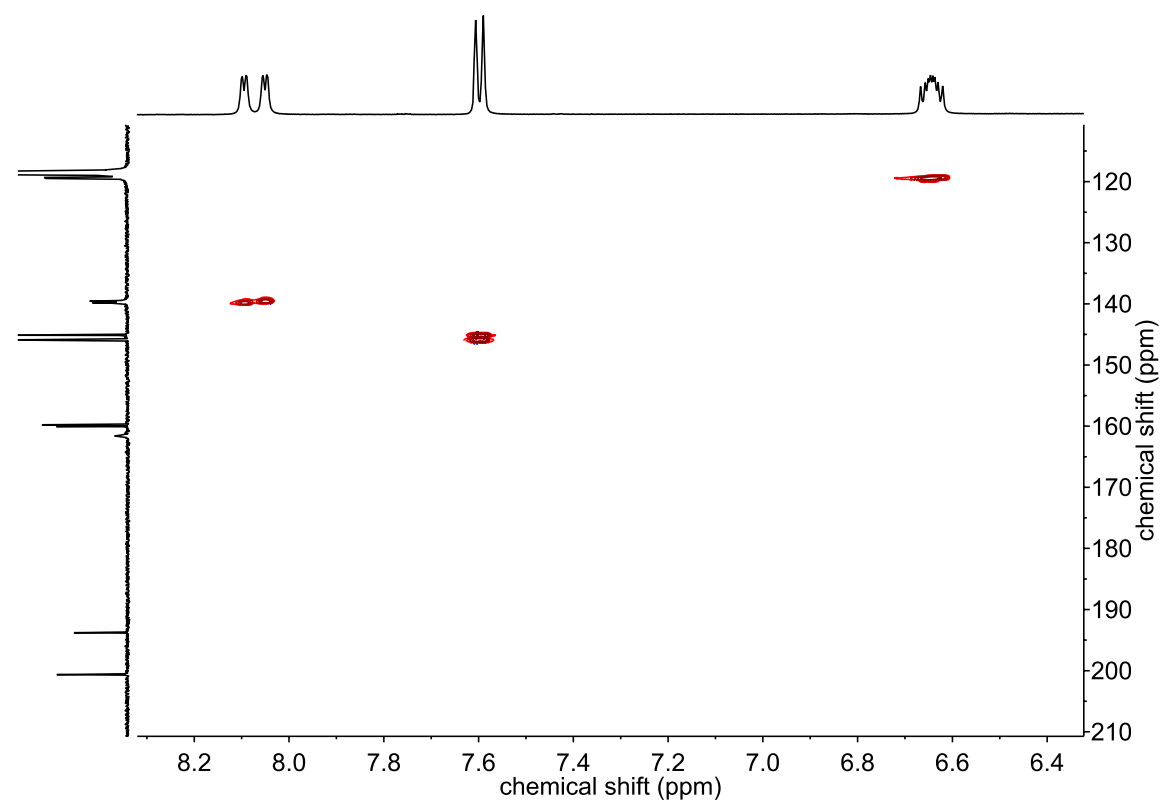

Figure S38. ${ }^{1} \mathrm{H}^{-13} \mathrm{C}$ HSQC NMR spectrum of $\mathbf{1}^{2-}$ in $\mathrm{MeCN}-\mathrm{d}_{3}$ at $243 \mathrm{~K}$. 


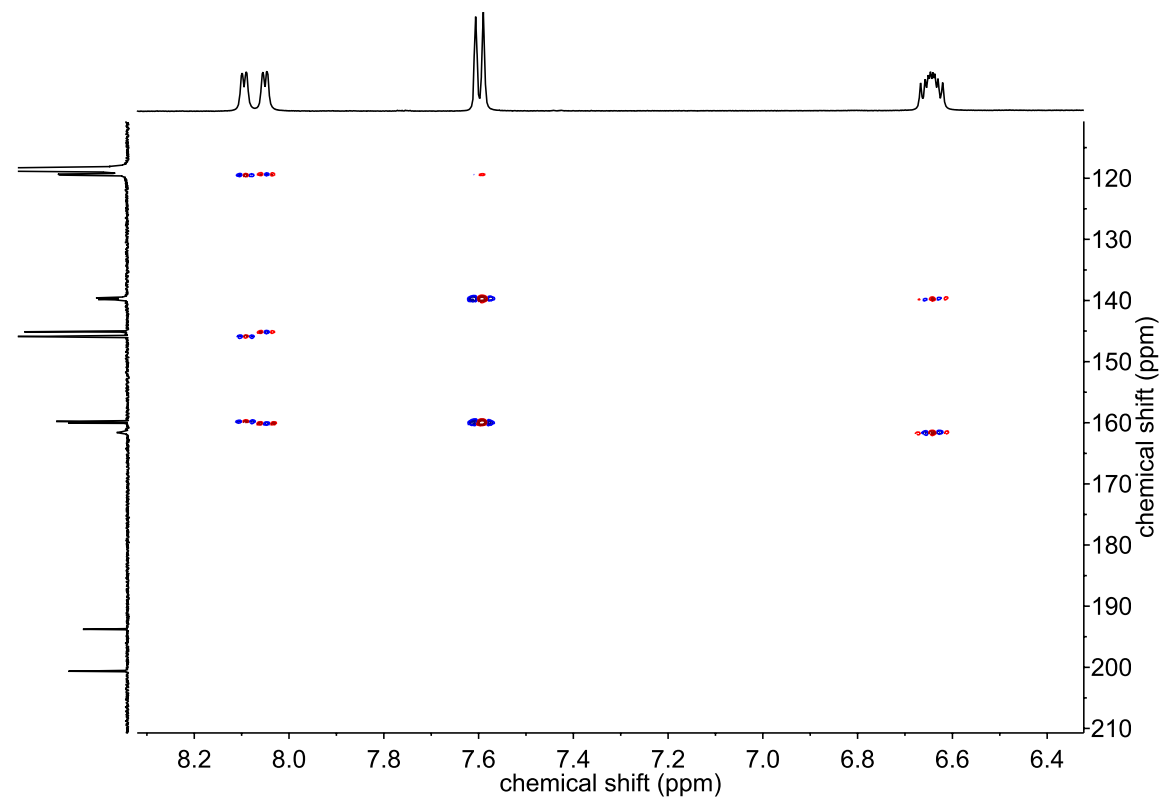

Figure S39. ${ }^{1} \mathrm{H}^{-13} \mathrm{C} \mathrm{HMBC} \mathrm{NMR} \mathrm{spectrum} \mathrm{of} \mathbf{1}^{2-}$ in $\mathrm{MeCN}-d_{3}$ at $243 \mathrm{~K}$.

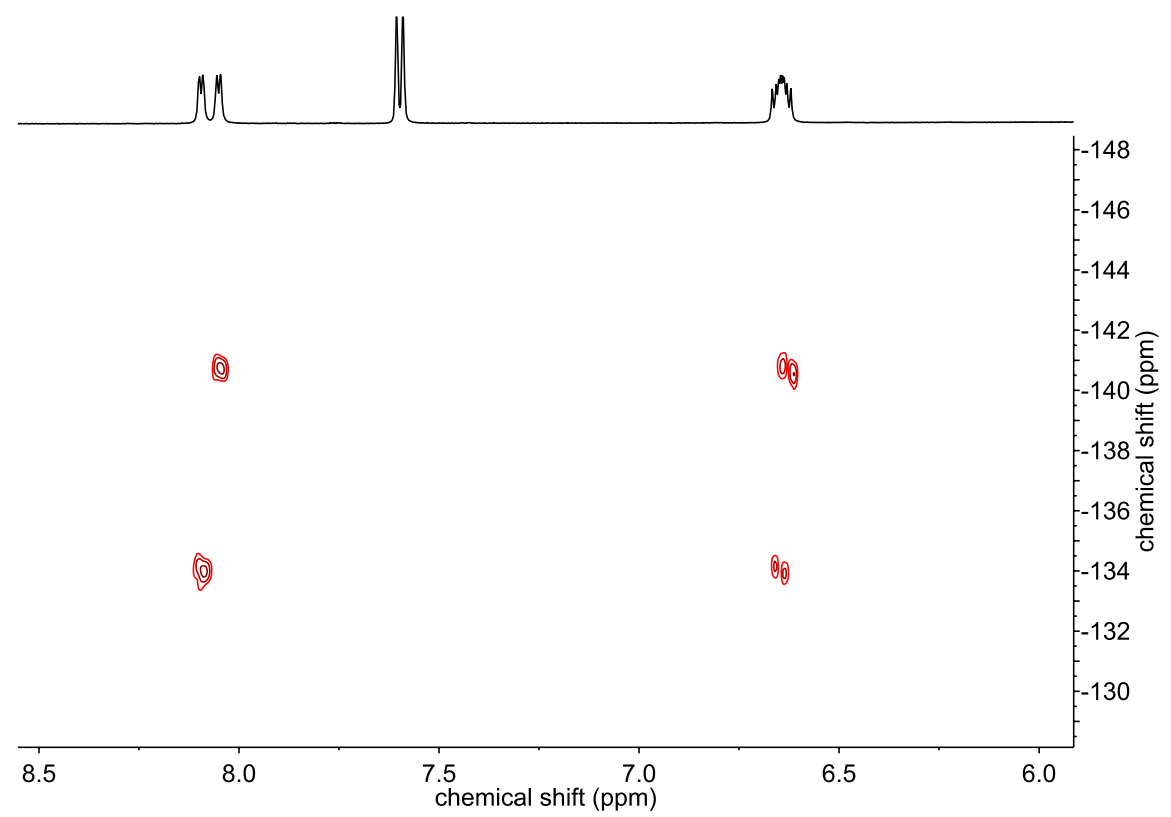

Figure S40. ${ }^{1} \mathrm{H}^{-14} \mathrm{~N} H M B C \mathrm{NMR}$ spectrum of $\mathbf{1}^{2-}$ in MeCN-d $\mathrm{d}_{3}$ at $243 \mathrm{~K}$. 

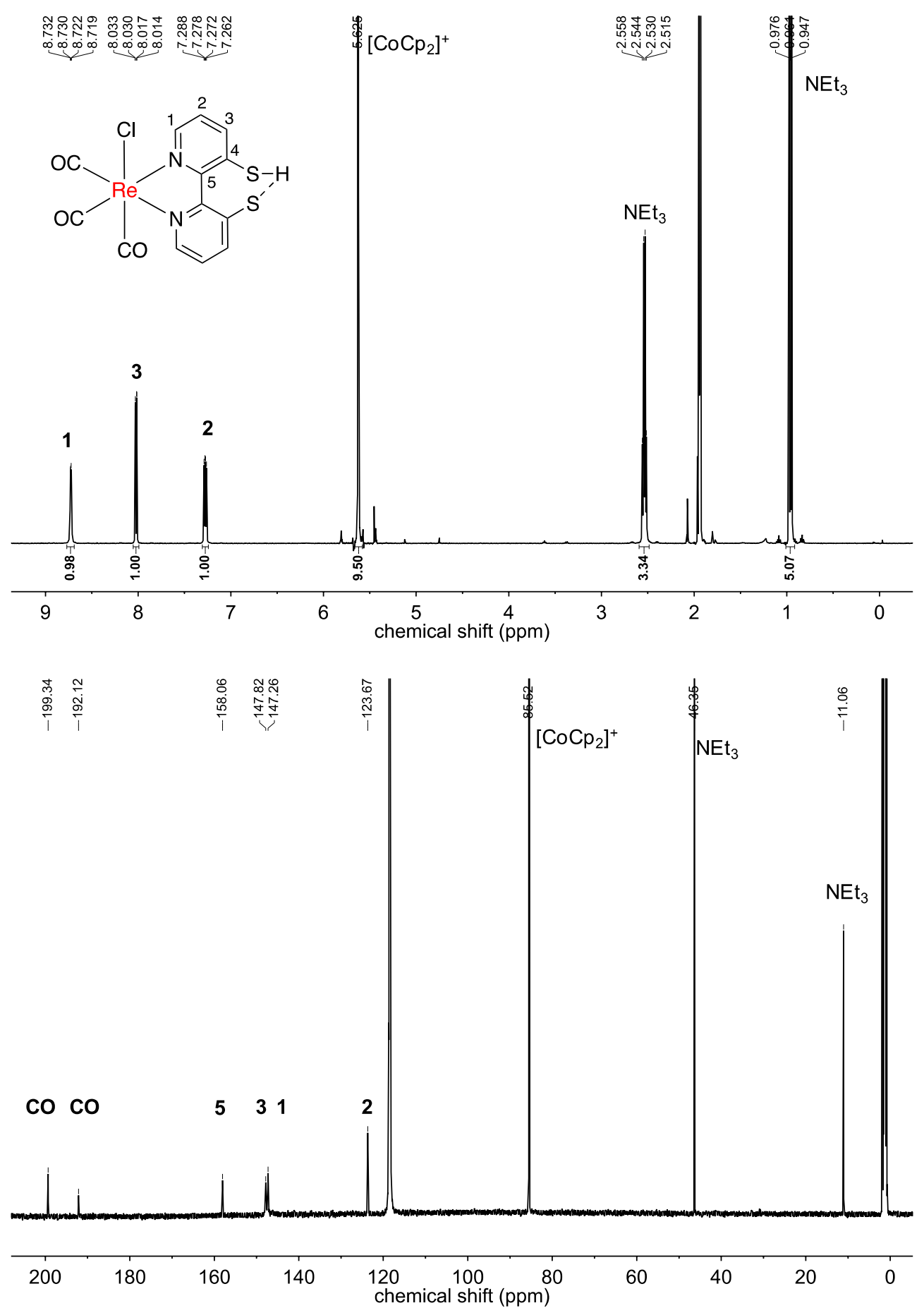

Figure S41. ${ }^{1} \mathrm{H}$ (top) and ${ }^{13} \mathrm{C}\left\{{ }^{1} \mathrm{H}\right\}$ (bottom) NMR spectra of $1 \mathrm{H}^{-}$in $\mathrm{MeCN}-\mathrm{d}_{3}$ at $243 \mathrm{~K}$. 


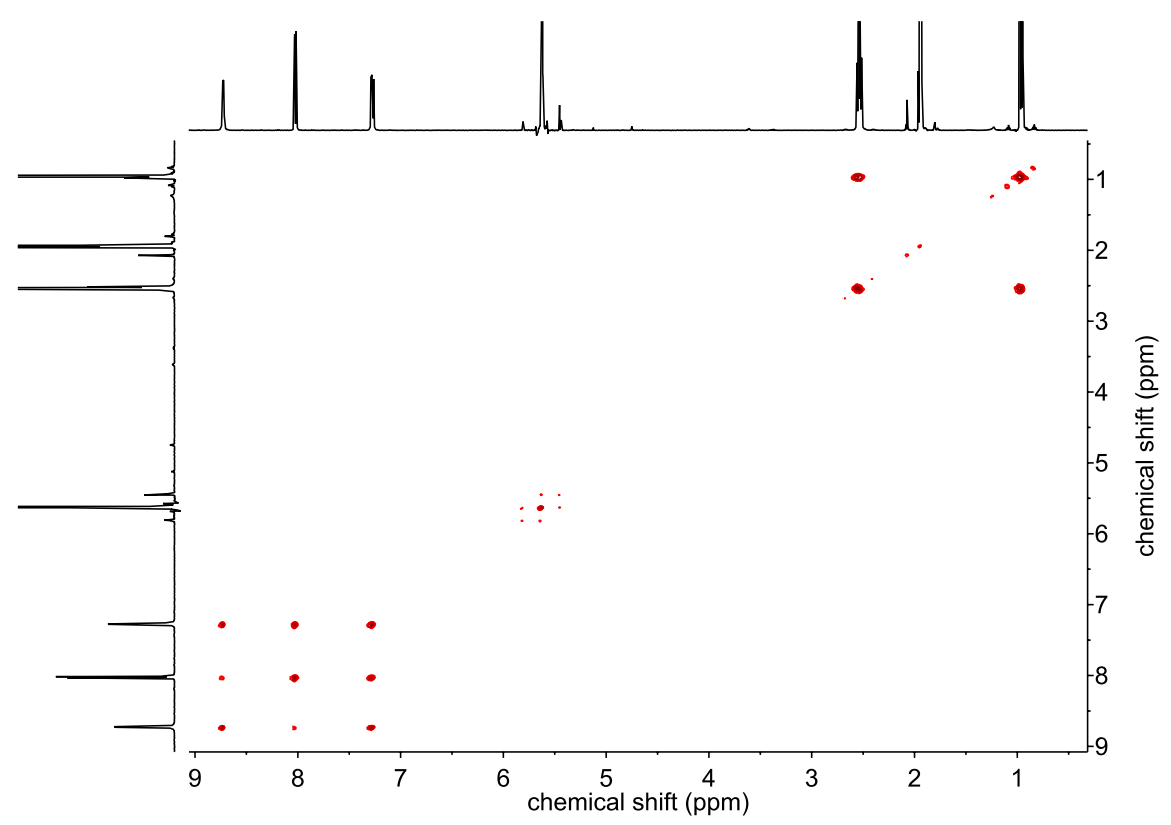

Figure S42. ${ }^{1} \mathrm{H}^{-13} \mathrm{C}$ COSY NMR spectrum of $1 \mathrm{H}^{-}$in $\mathrm{MeCN}-\mathrm{d}_{3}$ at $243 \mathrm{~K}$.

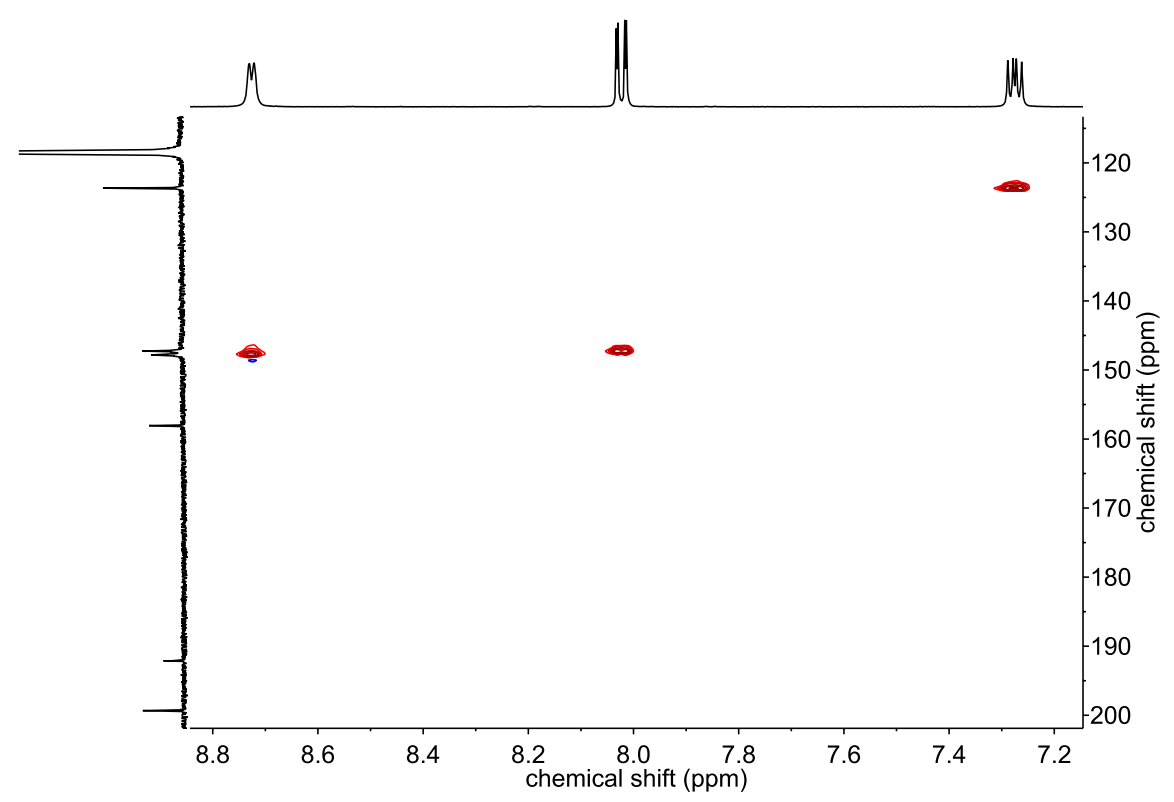

Figure S43. ${ }^{1} \mathrm{H}^{-13} \mathrm{C} \mathrm{HSQC} \mathrm{NMR} \mathrm{spectrum} \mathrm{of} 1 \mathrm{H}^{-}$in $\mathrm{MeCN}-\mathrm{d}_{3}$ at $243 \mathrm{~K}$. 


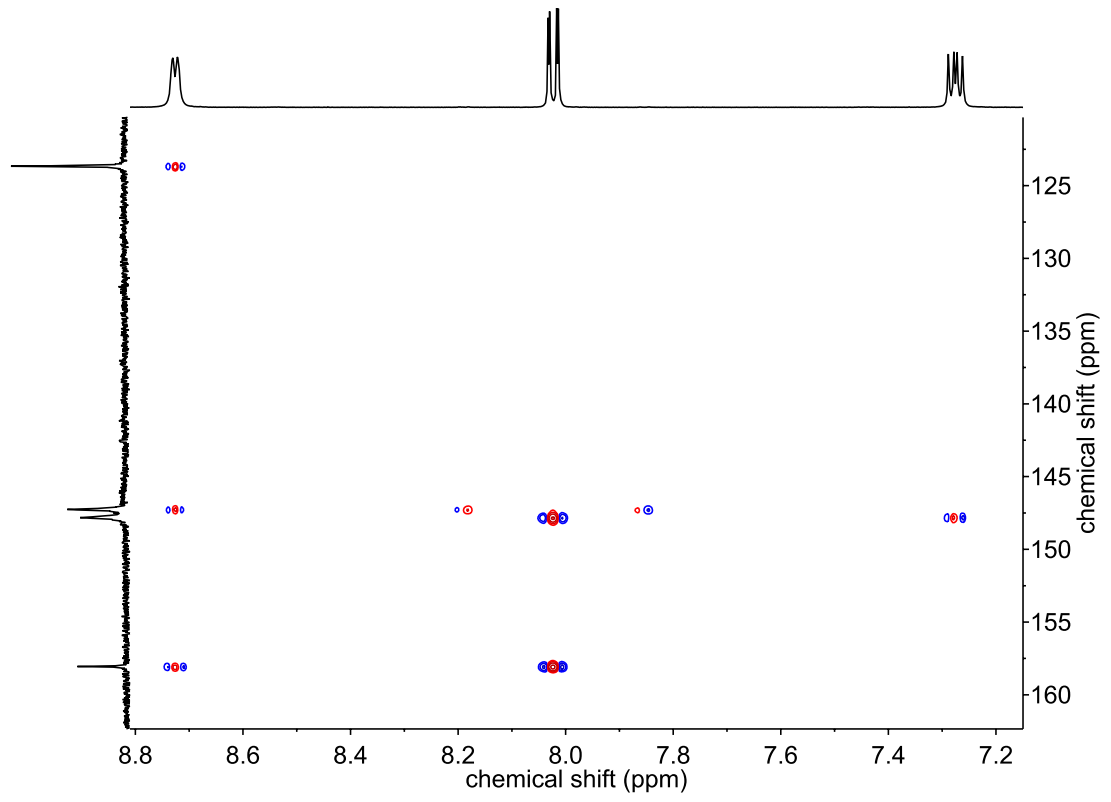

Figure S44. ${ }^{1} \mathrm{H}^{-13} \mathrm{C} H M B C N M R$ spectrum of $1 \mathrm{H}^{-}$in $\mathrm{MeCN}-d_{3}$ at $243 \mathrm{~K}$. 


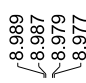

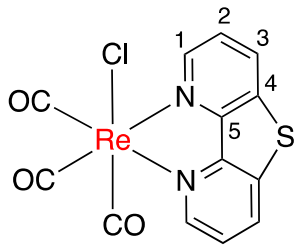
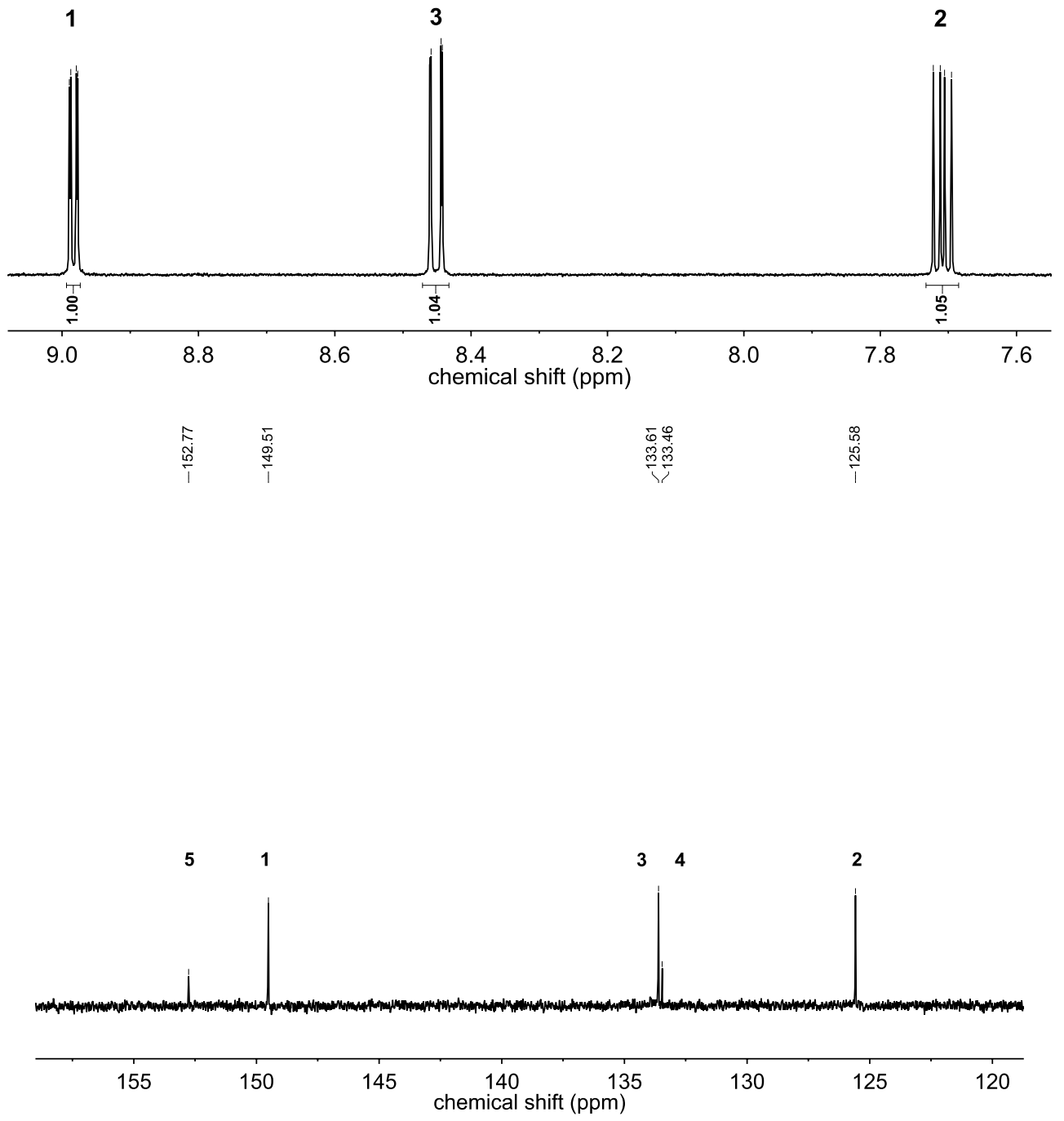

Figure $\mathbf{S 4 5} .{ }^{1} \mathrm{H}$ (top) and ${ }^{13} \mathrm{C}\left\{{ }^{1} \mathrm{H}\right\}$ (bottom) NMR spectra of 2 in $\mathrm{CDCl}_{3}$ at $298 \mathrm{~K}$. 


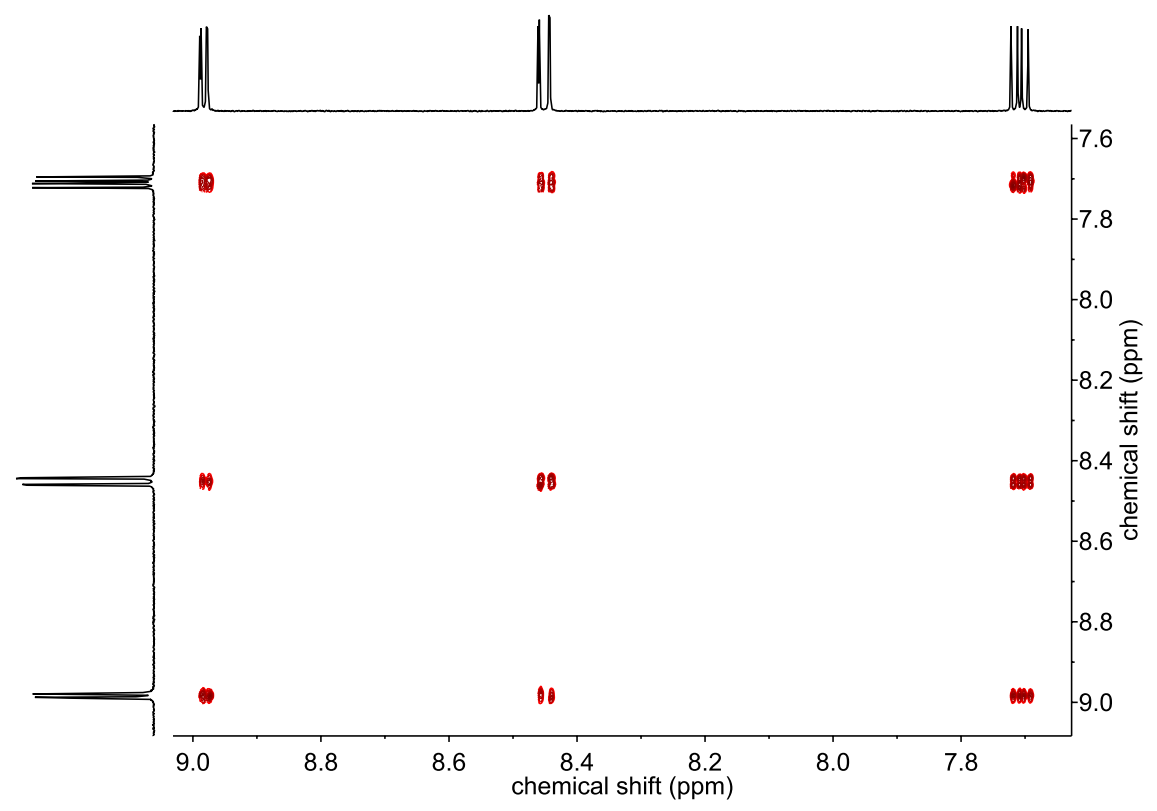

Figure S46. ${ }^{1} \mathrm{H}^{-1} \mathrm{H}$ COSY NMR spectrum of 2 in $\mathrm{CDCl}_{3}$ at $298 \mathrm{~K}$.

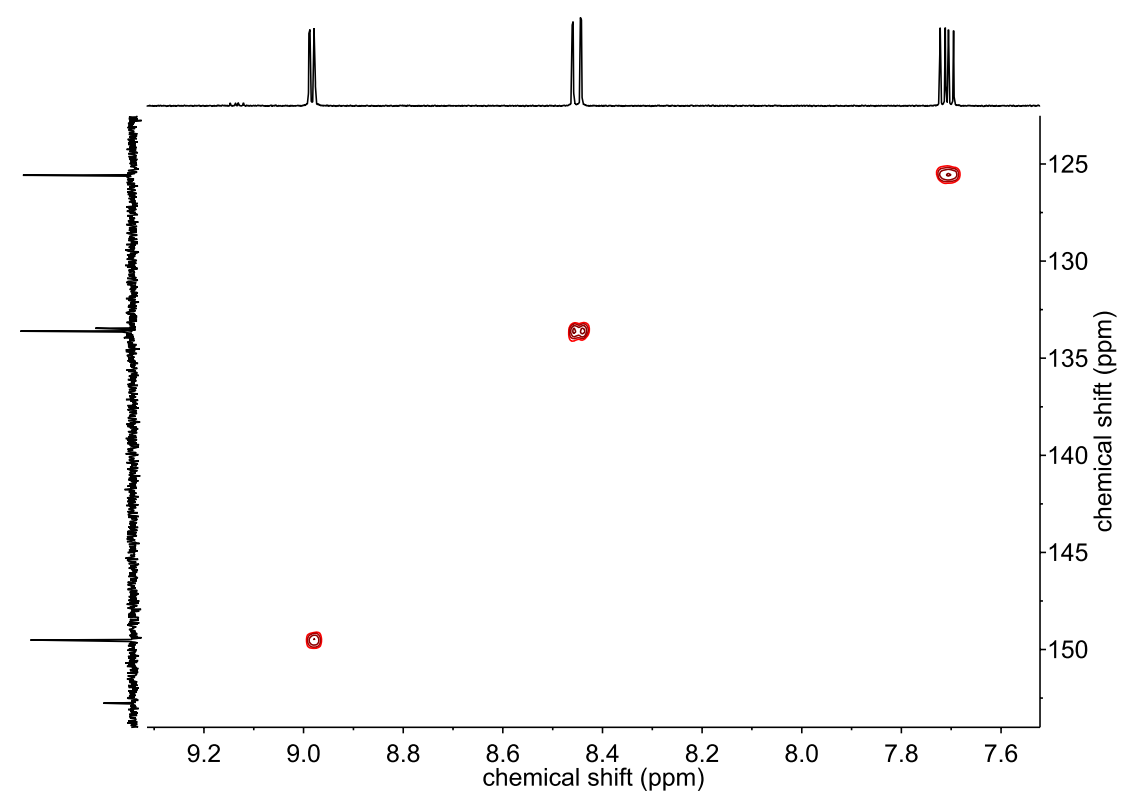

Figure S47. ${ }^{1} \mathrm{H}^{-13} \mathrm{C} \mathrm{HSQC}$ NMR spectrum of 2 in $\mathrm{CDCl}_{3}$ at $298 \mathrm{~K}$. 


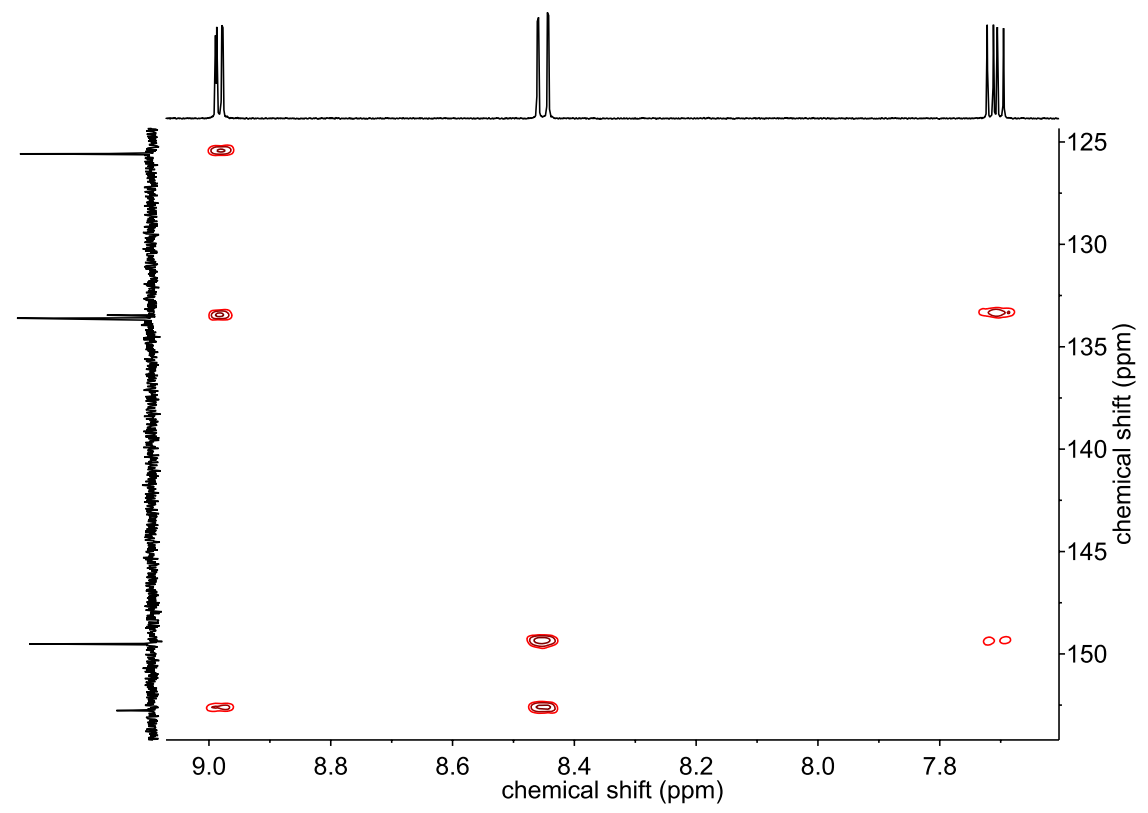

Figure S48. ${ }^{1} \mathrm{H}^{-13} \mathrm{C} \mathrm{HMBC} \mathrm{NMR} \mathrm{spectrum} \mathrm{of} 2$ in $\mathrm{CDCl}_{3}$ at $298 \mathrm{~K}$. 

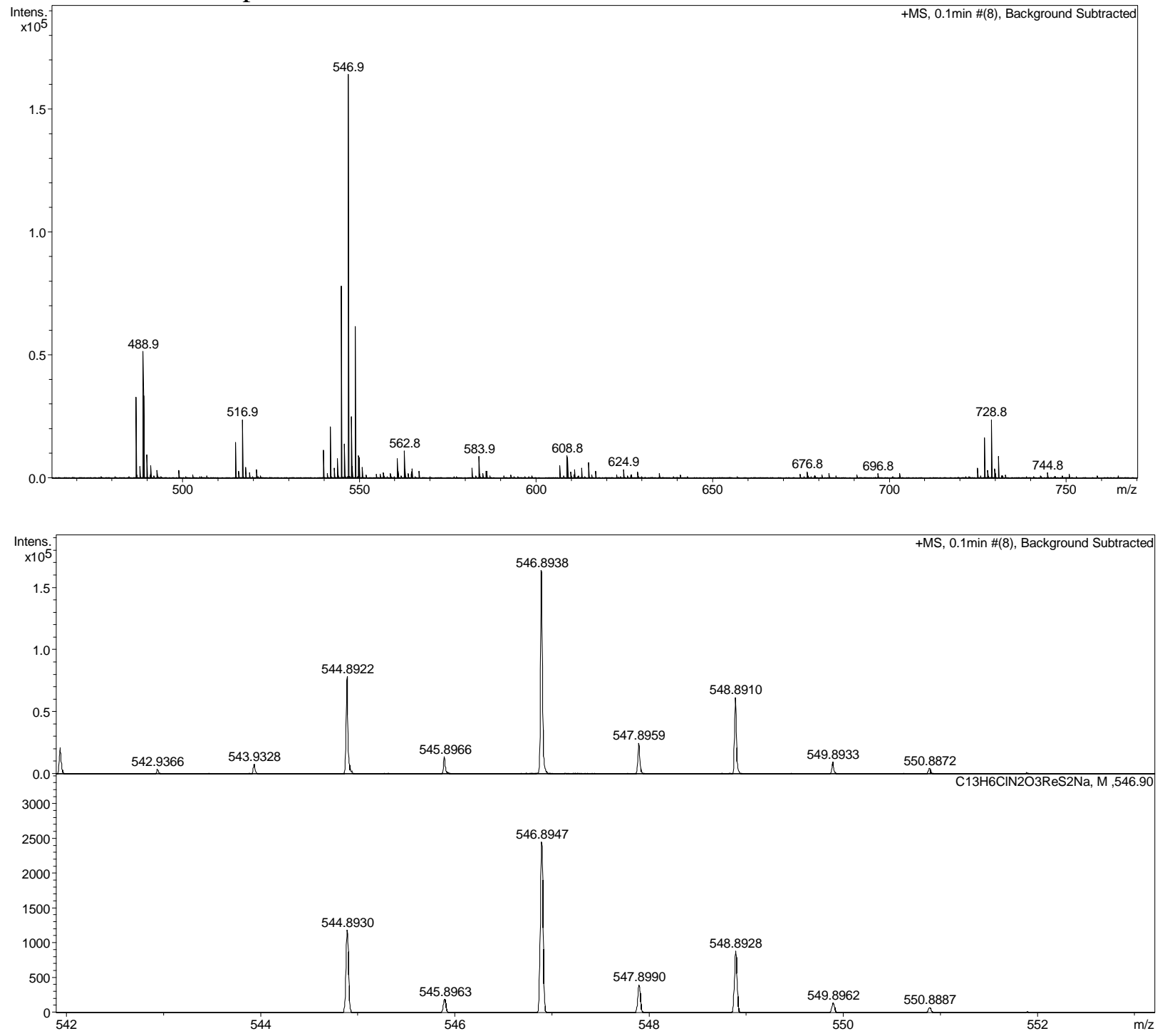

Figure S49. (Top) ESI(+)-mass spectrum of a $\mathrm{CH}_{2} \mathrm{Cl}_{2}$ solution of 1 and (bottom) experimental and simulated isotopic distribution for the peak pattern at $\mathrm{m} / \mathrm{z}=546.89$ for $\left[\mathrm{Re}\left({ }^{S-S} \text { bpy }\right)(\mathrm{CO})_{3} \mathrm{Cl}+\mathrm{Na}\right]^{+}$. 

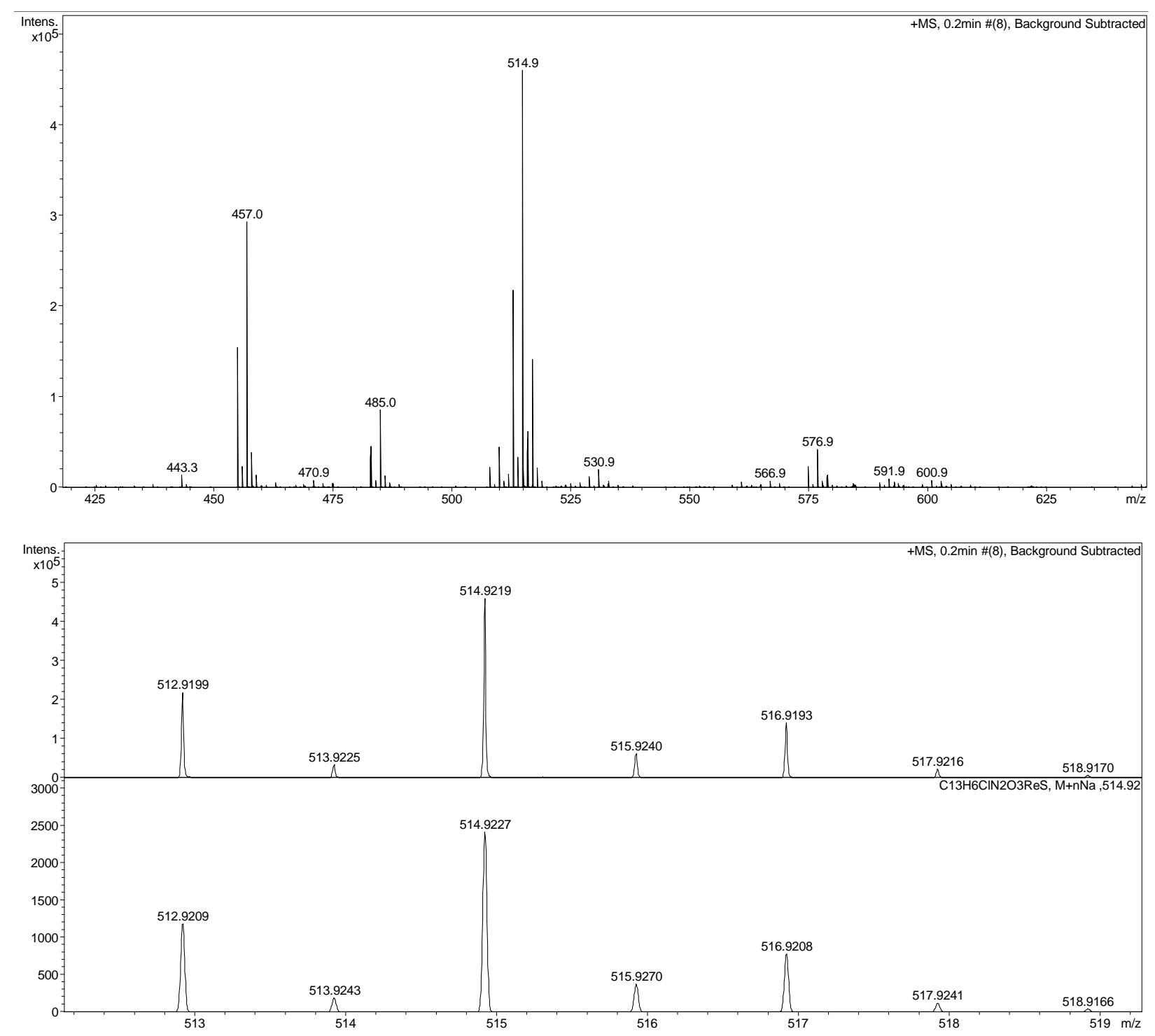

Figure S50. (Top) ESI(+)-mass spectrum of a $\mathrm{CHCl}_{3}$ solution of 2 and (bottom) simulated isotopic distribution for the peak pattern at $\mathrm{m} / \mathrm{z}=514.92$ for $\left[\operatorname{Re}\left({ }^{S} \text { bpy }\right)(\mathrm{CO})_{3} \mathrm{Cl}+\mathrm{Na}\right]^{+}$. 
5.5. IR Spectra
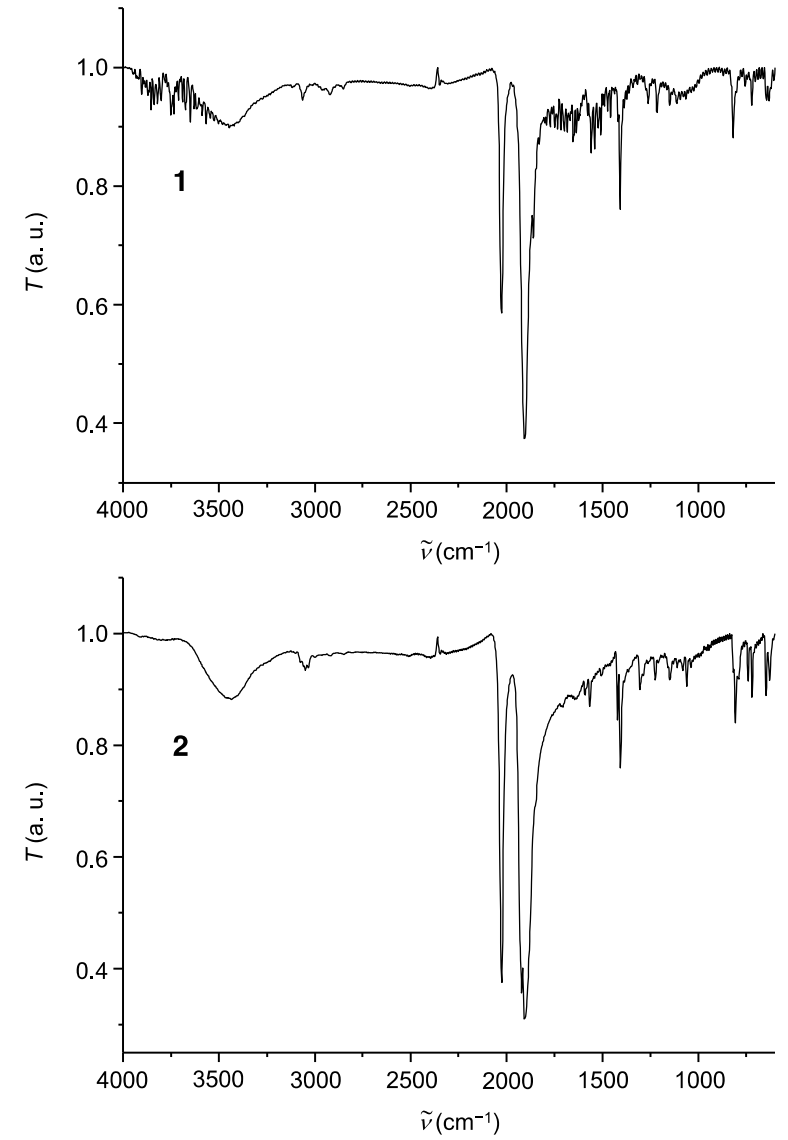

Figure S51. IR spectra of 1 (top) and 2 (bottom) in $\mathrm{KBr}$. 


\section{DFT/TD-DFT Calculations}

Density functional theory (DFT) computations were performed with Orca 3.0.3. ${ }^{27}$ Geometries of $\mathbf{1}, \mathbf{1}^{2-}$ and $1 \mathrm{H}^{-}$were optimized in $\mathrm{MeCN}$ using the $\mathrm{B}^{2} \mathrm{LYP}^{28}$ hybrid functional combined with the $6-31 \mathrm{G}(\mathrm{d}, \mathrm{p})^{29}$ basis set for nonmetal atoms and the def2-TZVP ${ }^{30}$ effective core potential and basis set for the rhenium atom. Optimized structures were confirmed with vibrational analysis and were shown in Figure S52 with the selected structural parameters were listed in Table S9. UV-vis spectra were computed by timedependent DFT (TD-DFT) ${ }^{31}$ calculations at B3LYP / 6-31G(d,p)- def2-TZVP level of theory employing 60 states based on the optimized structures. All computations included implicit solvent using the Conductor Like Screening Model (COSMO) $)^{32}$ with the default values for acetonitrile $(\varepsilon=36.6)$.

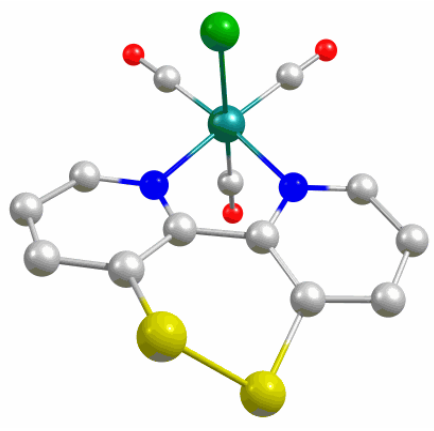

1

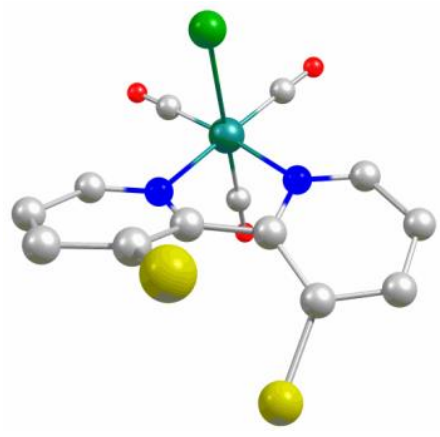

$1^{2-}$

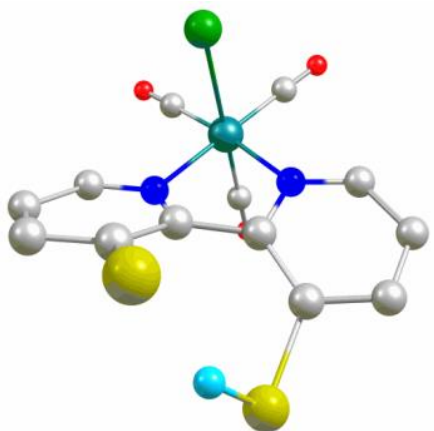

$1 \mathrm{H}^{-}$

Figure S52. Visualization of the optimized geometries of $1,1^{2-}$ and $1 H^{-}$based on DFT calculations at B3LYP level. (teal: Re; blue: $N$; yellow: $S$; grey: $C$; red: $O$; turquoise: $H$ ).

Table S9. Selected structural parameters of B3LYP optimized geometries of $1, \mathbf{1}^{2-}, 1 \mathrm{H}^{-}$and the experimental determined values of $\mathbf{1}$.

\begin{tabular}{lllll}
\hline & $\mathbf{1}_{\text {(exp.) }}$ & $\mathbf{1}$ & $\mathbf{1}^{2-}$ & $\mathbf{1 H}^{-}$ \\
\hline $\mathrm{Re}-\mathrm{Cl} 1(\AA)$ & 2.470 & 2.524 & 2.540 & 2.531 \\
$\mathrm{Re}-\mathrm{N} 1(\AA)$ & 2.173 & 2.199 & 2.195 & 2.199 \\
$\mathrm{Re}-\mathrm{N} 2(\AA)$ & 2.176 & 2.200 & 2.200 & 2.202 \\
$\mathrm{Re}-\mathrm{CO} 1(\AA)$ & 1.916 & 1.931 & 1.929 & 1.929 \\
$\mathrm{Re}-\mathrm{CO} 2(\AA)$ & 1.921 & 1.931 & 1.927 & 1.928 \\
$\mathrm{Re}-\mathrm{CO} 3(\AA)$ & 1.919 & 1.915 & 1.907 & 1.911 \\
$\mathrm{~S} 1-\mathrm{S} 2(\AA)$ & 2.048 & 2.092 & 3.394 & 3.257 \\
$\mathrm{~S} 1 \cdots \mathrm{H}-\mathrm{S} 2$ & & & & 1.901 \\
$\mathrm{C}-\mathrm{S} 1-\mathrm{S} 2-\mathrm{C}\left(^{\circ}\right)$ & 55.84 & 54.90 & 73.92 & 67.20
\end{tabular}




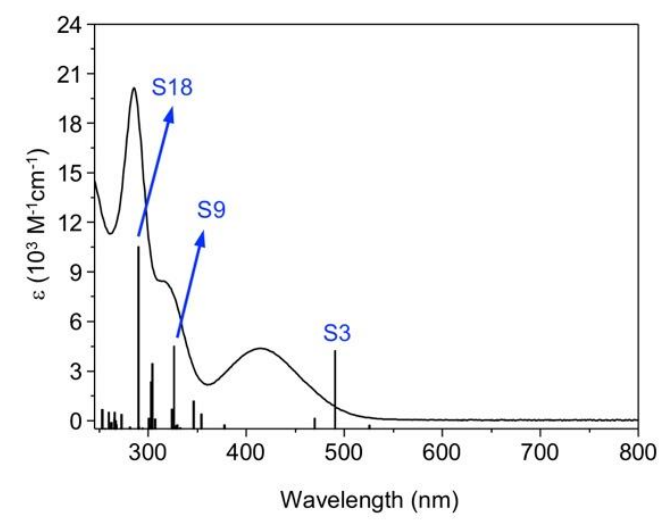

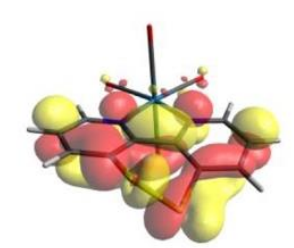

LUMO

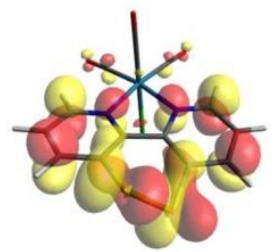

LUMO+1

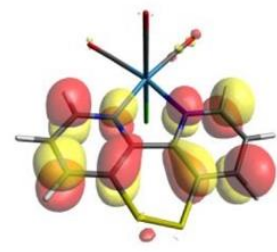

LUMO+2

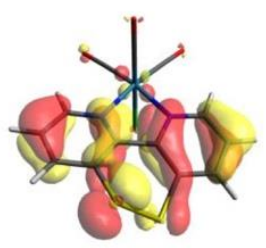

HOMO-5

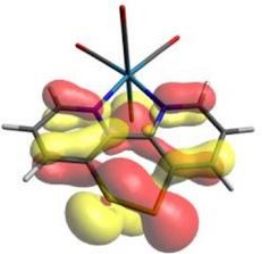

HOMO-4

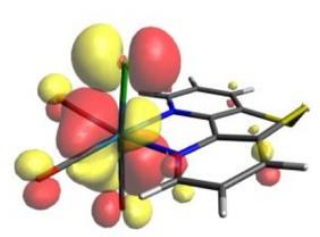

HOMO-1

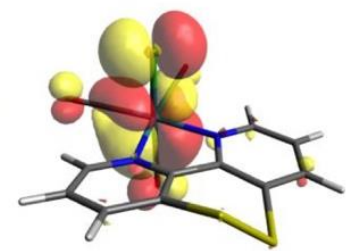

HOMO

Figure S53. Overlap of experimental UV-vis absorption spectra of 1 with calculated excitation states and selected frontier molecular orbitals contributing to the charge transfer excitations.

Table S10. Selected TD-DFT (B3LYP level) calculated energies, oscillator strengths, and compositions of the major electronic transitions of 1 .

\begin{tabular}{|c|c|c|c|c|}
\hline States & $\begin{array}{l}\text { Energy } \\
\left(\mathrm{cm}^{-1}\right)\end{array}$ & $\begin{array}{l}\text { Wavelength } \\
(\mathrm{nm})\end{array}$ & Osc. Strength & Major contributions \\
\hline 3 & 20386.8 & 490.5 & 0.058182285 & HOMO-1 $\rightarrow$ LUMO (MLCT, 95\%) \\
\hline 6 & 28918.2 & 345.8 & 0.020641123 & $\begin{array}{l}\text { HOMO-2 } \rightarrow \text { LUMO+1 (Ligand, 73\%); HOMO-1 } \rightarrow \\
\text { LUMO+1 (MLCT, 13\%) }\end{array}$ \\
\hline 9 & 30685.5 & 325.9 & 0.061769722 & $\begin{array}{l}\text { HOMO } \rightarrow \text { LUMO+2 (MLCT, 60\%); HOMO-4 } \rightarrow \\
\text { LUMO (Ligand, 25\%) }\end{array}$ \\
\hline 18 & 34548.2 & 289.5 & 0.135467639 & HOMO-4/HOMO-5 $\rightarrow$ LUMO (Ligand, 95\%) \\
\hline
\end{tabular}




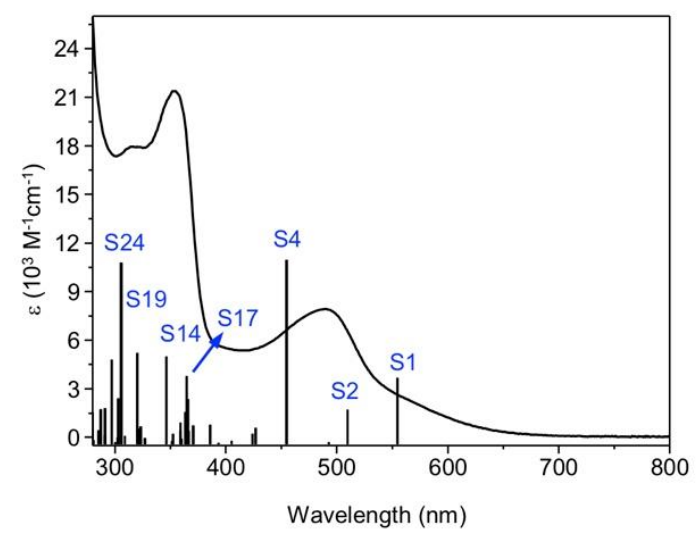

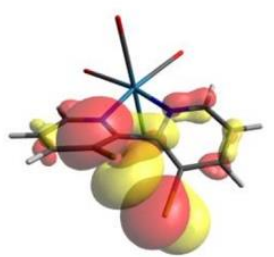

HOMO

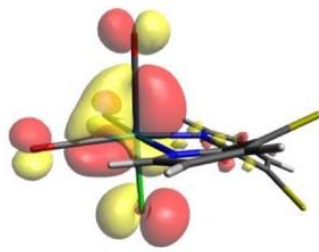

HOMO-5

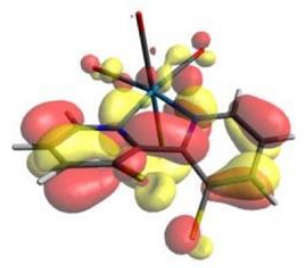

LUMO

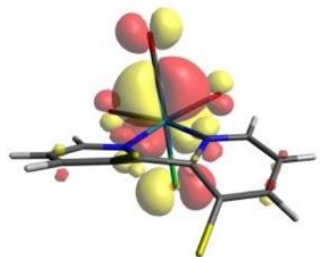

HOMO-4

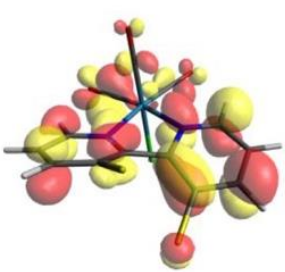

LUMO+2

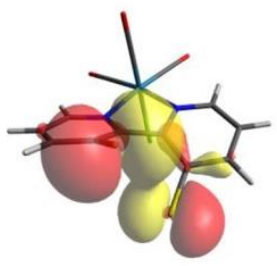

HOMO-3

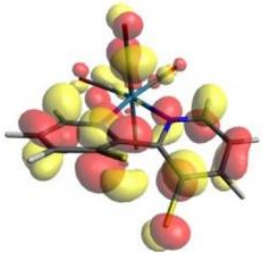

LUMO+4

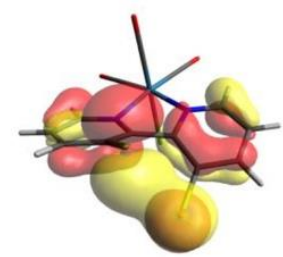

HOMO-1

Figure S54. Overlap of experimental UV-vis absorption spectra of $\mathbf{1}^{2-}$ with calculated excitation states and selected frontier molecular orbitals contributing to the charge transfer excitations.

Table S11. Selected TD-DFT (B3LYP level) calculated energies, oscillator strengths, and compositions of the major electronic transitions of $\mathbf{1}^{2-}$.

\begin{tabular}{|c|c|c|c|c|}
\hline States & $\begin{array}{l}\text { Energy } \\
\left(\mathrm{cm}^{-1}\right)\end{array}$ & $\begin{array}{l}\text { Wavelength } \\
(\mathrm{nm})\end{array}$ & Osc. Strength & Major contributions \\
\hline 1 & 18026.4 & 554.7 & 0.040102435 & HOMO $\rightarrow$ LUMO (Ligand, 95\%) \\
\hline 2 & 19621.9 & 509.6 & 0.020797404 & HOMO-1/HOMO-3 $\rightarrow$ LUMO (Ligand, 90\%) \\
\hline 4 & 21993.6 & 454.7 & 0.111736832 & HOMO-1/HOMO-3 $\rightarrow$ LUMO (Ligand, 90\%) \\
\hline 14 & 28863.3 & 346.5 & 0.053163003 & HOMO-5 $\rightarrow$ LUMO (MLCT, 85\%) \\
\hline 17 & 27426.7 & 364.6 & 0.041299226 & $\begin{array}{l}\mathrm{HOMO}-3 \rightarrow \text { LUMO+1/LUMO+2 (Ligand, 60\%); } \\
\mathrm{HOMO} \rightarrow \text { LUMO+4 (Ligand, 20\%) }\end{array}$ \\
\hline 19 & 31252.4 & 320.0 & 0.055290720 & HOMO- $1 \rightarrow$ LUMO+4 (Ligand, 75\%) \\
\hline 22 & 32358.5 & 309.0 & 0.004910666 & $\mathrm{HOMO}-4 \rightarrow \mathrm{LUMO}+1 / \mathrm{LUMO}+2(\mathrm{MLCT}, 65 \%)$ \\
\hline 24 & 32727.6 & 305.6 & 0.109962036 & $\begin{array}{l}\mathrm{HOMO}-5 \rightarrow \text { LUMO+1/LUMO+2/LUMO+3 (Ligand, } \\
40 \% \text { ); HOMO- } 3 \rightarrow \text { LUMO+4 (Ligand, } 40 \% \text { ) }\end{array}$ \\
\hline
\end{tabular}




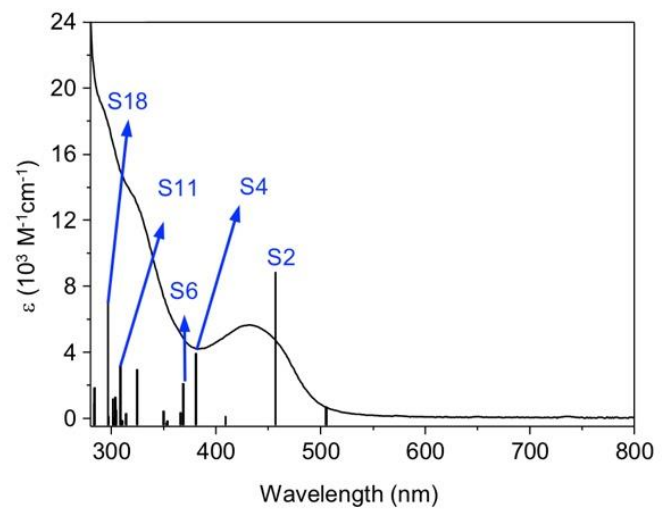

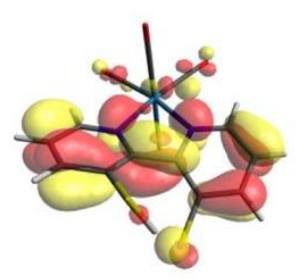

LUMO

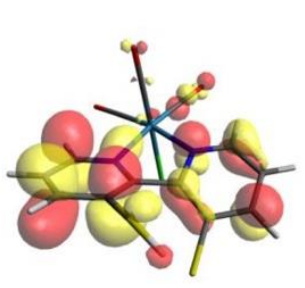

LUMO+1

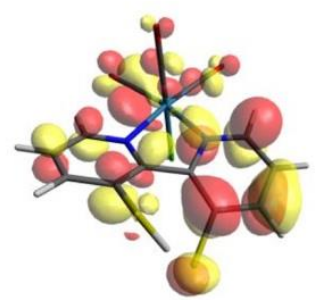

LUMO+2

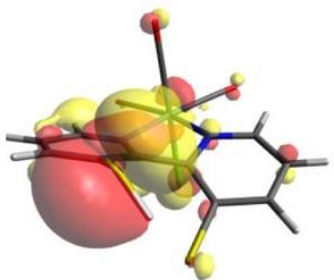

HOMO-4

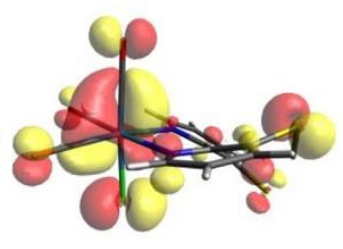

HOMO-3

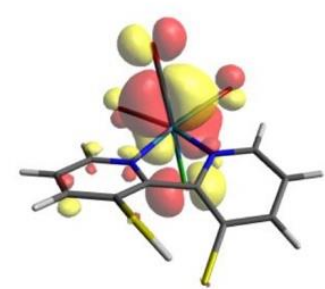

HOMO-2

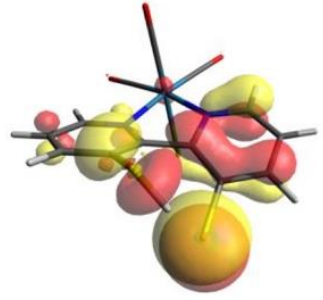

HOMO

Figure S55. Overlap of experimental UV-vis absorption spectra of $1 \mathrm{H}^{-}$with calculated excitation states and selected frontier molecular orbitals contributing to the charge transfer excitations.

Table S12. Selected TD-DFT (B3LYP level) calculated energies, oscillator strengths, and compositions of the major electronic transitions of $1 \mathrm{H}^{-}$.

\begin{tabular}{|c|c|c|c|c|}
\hline States & $\begin{array}{l}\text { Energy } \\
\left(\mathrm{cm}^{-1}\right)\end{array}$ & $\begin{array}{l}\text { Wavelength } \\
(\mathrm{nm})\end{array}$ & Osc. Strength & Major contributions \\
\hline 2 & 21880.4 & 457.0 & 0.075300811 & HOMO $\rightarrow$ LUMO (Ligand, 95\%) \\
\hline 4 & 26255.9 & 380.9 & 0.035078991 & HOMO-3 $\rightarrow$ LUMO (MLCT, 91\%) \\
\hline 6 & 27146.0 & 368.4 & 0.020041907 & $\begin{array}{l}\text { HOMO-4 } \rightarrow \text { LUMO (Ligand, 55\%); HOMO-4 } \rightarrow \\
\text { LUMO }+1 \text { (Ligand, 30\%) }\end{array}$ \\
\hline 11 & 31856.9 & 313.9 & 0.005409759 & HOMO-2 $\rightarrow$ LUMO+1/LUMO+2 (MLCT, 70) \\
\hline 18 & 33739.3 & 296.4 & 0.060315912 & $\begin{array}{l}\text { HOMO }-4 \rightarrow \text { LUMO+1 (Ligand, 50\%); HOMO-6 } \rightarrow \\
\text { LUMO (Ligand, 20\%) }\end{array}$ \\
\hline
\end{tabular}




\section{Cartesian Coordinates}

\section{1}

$\begin{array}{lrrr}\mathrm{Re} & 0.044452 & 0.000716 & 0.036228 \\ \mathrm{Cl} & -0.038723 & 0.158343 & -2.481787 \\ \mathrm{~S} & -3.452935 & 4.616882 & 0.084082 \\ \mathrm{~S} & -4.302989 & 3.472451 & -1.446606 \\ \mathrm{O} & 3.140267 & -0.030540 & 0.039527 \\ \mathrm{O} & 0.014290 & -3.095382 & -0.002215 \\ \mathrm{O} & 0.002717 & -0.022753 & 3.119457 \\ \mathrm{~N} & -0.228058 & 2.181407 & -0.028719 \\ \mathrm{~N} & -2.122951 & 0.319096 & -0.170300 \\ \mathrm{C} & 0.779505 & 3.049100 & 0.175524 \\ \mathrm{H} & 1.771448 & 2.627064 & 0.270559 \\ \mathrm{C} & 0.569279 & 4.419507 & 0.275216 \\ \mathrm{H} & 1.410421 & 5.084752 & 0.431685 \\ \mathrm{C} & -0.731325 & 4.906926 & 0.187651 \\ \mathrm{H} & -0.934084 & 5.968279 & 0.287626 \\ \mathrm{C} & -1.781549 & 4.009465 & -0.023638 \\ \mathrm{C} & -1.501623 & 2.635694 & -0.161857 \\ \mathrm{C} & -2.524650 & 1.596946 & -0.399152 \\ \mathrm{C} & -3.827718 & 1.856565 & -0.865171 \\ \mathrm{C} & -4.725165 & 0.796955 & -1.024099 \\ \mathrm{H} & -5.733408 & 0.986394 & -1.376639 \\ \mathrm{C} & -4.304146 & -0.496745 & -0.731599 \\ \mathrm{H} & -4.973409 & -1.343030 & -0.834281 \\ \mathrm{C} & -2.990746 & -0.697270 & -0.322671 \\ \mathrm{H} & -2.613548 & -1.691157 & -0.120846 \\ \mathrm{C} & 1.975069 & -0.037305 & 0.042546 \\ \mathrm{C} & 0.042427 & -1.930449 & 0.015756 \\ \mathrm{C} & 0.017183 & -0.015709 & 1.950683\end{array}$

$\begin{array}{lrrr}\mathbf{1}^{2-} & & & \\ & & & \\ \mathrm{Re} & -0.040876 & 0.027708 & -0.007948 \\ \mathrm{Cl} & -0.211353 & -0.049514 & -2.541030 \\ \mathrm{~S} & -3.489890 & 4.385267 & 0.990040 \\ \mathrm{~S} & -4.221407 & 3.192880 & -2.102272 \\ \mathrm{O} & 3.054232 & 0.017686 & -0.137386 \\ \mathrm{O} & -0.029840 & -3.059404 & 0.235838 \\ \mathrm{O} & 0.055649 & 0.283138 & 3.059162 \\ \mathrm{~N} & -0.336373 & 2.197661 & -0.216614 \\ \mathrm{~N} & -2.214875 & 0.299643 & -0.145083 \\ \mathrm{C} & 0.675544 & 3.071813 & -0.100988 \\ \mathrm{H} & 1.679746 & 2.673034 & -0.170055 \\ \mathrm{C} & 0.435235 & 4.429127 & 0.112672 \\ \mathrm{H} & 1.265903 & 5.126055 & 0.157018 \\ \mathrm{C} & -0.868491 & 4.841584 & 0.348559 \\ \mathrm{H} & -1.075033 & 5.873161 & 0.618337 \\ \mathrm{C} & -1.951884 & 3.927883 & 0.322078 \\ \mathrm{C} & -1.639153 & 2.614692 & -0.157566 \\ \mathrm{C} & -2.623483 & 1.567048 & -0.465064 \\ \mathrm{C} & -3.851409 & 1.772000 & -1.171802 \\ \mathrm{C} & -4.741198 & 0.669001 & -1.182773 \\ \mathrm{H} & -5.720549 & 0.805658 & -1.631389 \\ \mathrm{C} & -4.361309 & -0.575634 & -0.701883 \\ \mathrm{H} & -5.037072 & -1.424402 & -0.732087 \\ \mathrm{C} & -3.054328 & -0.742741 & -0.245358 \\ \mathrm{H} & -2.668272 & -1.713636 & 0.037378 \\ \mathrm{C} & 1.886353 & 0.007832 & -0.087288\end{array}$




$\begin{array}{llll}\mathrm{C} & -0.021494 & -1.893386 & 0.144838 \\ \mathrm{C} & 0.017166 & 0.184395 & 1.891608\end{array}$

\section{$1 \mathrm{H}^{-}$}

$\begin{array}{lrrc}\text { Re } & 0.009002 & -0.004160 & -0.021136 \\ \text { Cl } & -0.160411 & 0.163998 & -2.541105 \\ \text { S } & -3.538392 & 4.392125 & 1.044515 \\ \text { S } & -4.257275 & 3.259632 & -1.923209 \\ \text { O } & 3.102468 & 0.015491 & -0.149837 \\ \text { O } & 0.048182 & -3.099244 & -0.057940 \\ \text { O } & 0.092003 & -0.033142 & 3.058878 \\ \text { N } & -0.315252 & 2.174009 & -0.021849 \\ \text { N } & -2.168763 & 0.274342 & -0.152192 \\ \mathrm{C} & 0.686703 & 3.024702 & 0.249210 \\ \mathrm{H} & 1.691492 & 2.626096 & 0.189544 \\ \mathrm{C} & 0.454644 & 4.345357 & 0.615043 \\ \mathrm{H} & 1.286794 & 5.013190 & 0.805987 \\ \mathrm{C} & -0.861523 & 4.753361 & 0.785296 \\ \mathrm{H} & -1.084983 & 5.752572 & 1.143697 \\ \mathrm{C} & -1.925324 & 3.872899 & 0.523793 \\ \mathrm{C} & -1.619769 & 2.588087 & 0.003173 \\ \mathrm{C} & -2.591851 & 1.553365 & -0.412861 \\ \mathrm{C} & -3.811028 & 1.770440 & -1.114962 \\ \mathrm{C} & -4.670159 & 0.650244 & -1.245621 \\ \mathrm{H} & -5.637753 & 0.798661 & -1.713426 \\ \mathrm{C} & -4.278199 & -0.609542 & -0.831906 \\ \mathrm{H} & -4.929126 & -1.470769 & -0.936617 \\ \mathrm{C} & -2.984203 & -0.769872 & -0.334007 \\ \mathrm{H} & -2.590653 & -1.747973 & -0.089603 \\ \mathrm{C} & 1.936597 & -0.008376 & -0.099016 \\ \mathrm{C} & 0.047591 & -1.931751 & -0.043060 \\ \mathrm{C} & 0.059159 & -0.025287 & 1.888617 \\ \mathrm{H} & -4.142312 & 4.099873 & -0.222037\end{array}$

\section{References}

\footnotetext{
${ }^{1}$ Saba, S.; Hernandez, R.; Choy, C. C.; Carta, K.; Bennett, Y.; Bondi, S.; Kolaj, S.; Bennett, C. A Simple and Efficient One-Step Protocol for the Preparation of Alkyl-Substituted Ammonium Tetrafluoroborate and Hexafluorophosphate Salts. J. Fluor. Chem. 2013, 153, 168-171.

${ }^{2}$ Zhu, X. Q.; Zhang, M. T.; Yu, A.; Wang, C. H.; Cheng, J. P. Hydride, Hydrogen Atom, Proton, and Electron Transfer Driving Forces of Various Five-Membered Heterocyclic Organic Hydrides and their Reaction Intermediates in Acetonitrile. J. Am. Chem. Soc. 2008, 130, 2501-2516.

${ }^{3}$ Cattaneo, M.; Schiewer, C. E.; Schober, A.; Dechert, S.; Siewert, I.; Meyer, F. 2,2'-Bipyridine Equipped with a Disulfide/Dithiol Switch for Coupled Two-Electron and Two-Proton Transfer. Chem. Eur. J. 2018, 24, 48644870.

${ }^{4}$ Hua, S.-A.; Cattaneo, M.; Oelschlegel, M.; Heindl, M.; Schmid, L.; Dechert, S.; Wenger, O. S.; Siewert, I.; Gonzalez, L.; Meyer, F. Electrochemical and Photophysical Properties of Ruthenium(II) Complexes Equipped with Sulfurated Bipyridine Ligands. Inorg. Chem. 2020, 59, 4972-4984.

${ }^{5}$ N. G. Tsierkezos, Cyclic Voltammetric Studies of Ferrocene in Nonaqueous Solvents in the Temperature Range from 248.15 to 298.15 K. J. Solution Chem. 2007, 36, 289-302.

${ }^{6}$ Cattaneo, M.; Guo, F.; Kelly, H. R.; Videla, P. E.; Kiefer, L.; Gebre, S.; Ge, A.; Liu, Q.; Wu, S.; Lian, T.; Batista, V. S. Robust Binding of Disulfide-Substituted Rhenium Bipyridyl Complexes for $\mathrm{CO}_{2}$ Reduction on Gold Electrodes. Front. Chem. 2020, 8, 86.

${ }^{7}$ Talukdar, K.; Sinha Roy, S.; Amatya, E.; Sleeper, E. A.; Le Magueres, P.; Jurss, J. W. Enhanced Electrochemical $\mathrm{CO}_{2}$ Reduction by a Series of Molecular Rhenium Catalysts Decorated with Second-Sphere Hydrogen-Bond Donors. Inorg. Chem. 2020, 59, 6087-6099.

${ }^{8}$ J. M. Smieja, M. D. Sampson, K. A. Grice, E. E. Benson, J. D. Froehlich, C. P. Kubiak, Inorg Chem 2013, 52, 2484-2491.
} 
${ }^{9}$ Waldie, K. M.; Ostericher, A. L.; Reineke, M. H.; Sasayama, A. F.; Kubiak, C. P. Hydricity of Transition-Metal Hydrides: Thermodynamic Considerations for $\mathrm{CO}_{2}$ Reduction. ACS Catal. 2018, 8, 1313-1324.

${ }^{10}$ Pegis, M. L.; Roberts, J. A.; Wasylenko, D. J.; Mader, E. A.; Appel, A. M.; Mayer, J. M. Standard Reduction Potentials for Oxygen and Carbon Dioxide Couples in Acetonitrile and N,N-Dimethylformamide. Inorg. Chem. 2015, 54, 11883-11888.

${ }^{11}$ Lam, Y. C.; Nielsen, R. J.; Gray, H. B.; Goddard, W. A. A Mn Bipyrimidine Catalyst Predicted to Reduce $\mathrm{CO}_{2}$ at Lower Overpotential. ACS Catal. 2015, 5, 2521-2528.

${ }^{12}$ Appel, A. M.; Helm, M. L. Determining the Overpotential for a Molecular Electrocatalyst. ACS Catal. 2014, 4, 630-633.

${ }^{13}$ P. Zanello, C. Nervi, F. Fabrizi de Biani, Inorganic Electrochemistry: Theory, practice and application, $2^{\text {nd }}$ ed., RSC Pub., Cambridge, UK, 2012.

${ }_{14}$ (a) Sheldrick, G. M. Acta Cryst. 2015, A71, 3-8. (b) Sheldrick, G. M. Acta Cryst. 2015, C71, 3-8.

${ }^{15} X$-RED; STOE \& CIE GmbH, Darmstadt, Germany, 2002.

${ }^{16}$ Barman, S. K.; Jones, J. R.; Sun, C.; Hill, E. A.; Ziller, J. W.; Borovik, A. S. Regulating the Basicity of MetalOxido Complexes with a Single Hydrogen Bond and Its Effect on C-H Bond Cleavage. J. Am. Chem. Soc. 2019, $141,11142-11150$.

${ }^{17}$ Izutsu, K. Acid-Base Dissociation Constants in Dipolar Aprotic Solvents; IUPAC Chemical Data Series; Blackwell Science: Oxford, U.K., 1990.

${ }^{18}$ Leito, I.; Kaljurand, I.; Koppel, I. A.; Yagupolskii, L. M.; Vlasov, V. M., Spectrophotometric Acidity Scale of Strong Neutral Brønsted Acids in Acetonitrile. J. Org. Chem. 1998, 63 (22), 7868-7874.

${ }^{19}$ (a) Bordwell, F.; Cheng, J. P.; Harrelson, J. A. Homolytic Bond Dissociation Energies in Solution from Equilibrium Acidity and Electrochemical Data. J. Am. Chem. Soc. 1988, 110, 1229-1231. (b) Tilset, M.; Parker, V. D. Solution Homolytic Bond Dissociation Energies of Organotransition-Metal Hydrides. J. Am. Chem. Soc. 1989, 111, 6711-6717.

${ }^{20}$ Brereton, K.R.; Smith, N.E.; Hazari, N.; Miller, A.J.M. Thermodynamic and Kinetic Hydricity of Transition Metal Hydrides, Chem. Soc. Rev. 2020, 49 7929-7948.

${ }^{21}$ Berning, D. E.; Noll, B. C.; DuBois, D. L. Relative Hydride, Proton, and Hydrogen Atom Transfer Abilities of $\left.[\mathrm{HM} \text { (diphosphine })_{2}\right] \mathrm{PF}_{6}$ Complexes $(\mathrm{M}=\mathrm{Pt}, \mathrm{Ni})$. J. Am. Chem. Soc. 1999, 121, 11432-11447.

${ }^{22}$ Warren, J. J.; Tronic, T. A.; Mayer, J. M. Thermochemistry of Proton-Coupled Electron Transfer Reagents and its Implications. Chem. Rev. 2010, 110, 6961-7001.

${ }^{23}$ Wise, C. F.; Agarwal, R. G.; Mayer, J. M. Determining Proton-Coupled Standard Potentials and X-H Bond Dissociation Free Energies in Nonaqueous Solvents Using Open-Circuit Potential Measurements. J. Am. Chem. Soc. 2020, 142, 10681-10691.

${ }^{24}$ (a) Himmel, D.; Goll, S. K.; Leito, I.; Krossing, I. A Unified pH Scale for all Phases. Angew. Chem. Int. Ed. 2010, 49, 6885-6888. (b) Radtke, V.; Himmel, D.; Putz, K.; Goll, S. K.; Krossing, I. The protoelectric potential map (PPM): An Absolute Two-Dimensional Chemical Potential Scale for a Global Understanding of Chemistry. Chem. Eur. J. 2014, 20, 4194-4211.

${ }^{25}$ Bausch, M.; Guadalupe-Fasano, C.; Gostowski, R. Estimates of Solution-Phase Bond Dissociation Energies for Carbon-Sulfur and Sulfur-Sulfur Bonds in Radical Anions Derived from Aromatic Sulfides. Energy \& fuels 1991, $5,419-423$.

${ }^{26}$ Ali, G.; VanNatta, P. E.; Ramirez, D. A.; Light, K. M.; Kieber-Emmons, M. T. Thermodynamics of a $\mu$-oxo Dicopper(II) Complex for Hydrogen Atom Abstraction. J. Am. Chem. Soc. 2017, 139, 18448-18451, see Supporting Information.

${ }^{27}$ Neese, F. WIREs Comput. Mol. Sci. 2012, 2, 73-78.

${ }^{28}$ (a) Becke, A. Density-Functional Thermochemistry: The Role of Extract Exchange. J. Chem. Phys. 1993, 98, 5648-5652. (b) Lee, C.; Yang, W.; Parr, R. G. Development of the Colle-Salvetti Correlation-Energy Formula into a Functional of the Electron Density. Phys. Rev. B: Condens. Matter Mater. Phys. 1988, 37, 785.

${ }^{29}$ (a) Petersson, G. A.; Bennett, A.; Tensfeldt, T. G.; Al-Laham, M. A.; Shirley, W. A.; Mantzaris, J. A Complete Basis Set Model Chemistry. I. The Total Energies of Closed-Shell Atoms and Hydrides of the First-Row Elements. J. Chem. Phys. 1988, 89, 2193-2218. (b) Petersson, G. A.; Al-Laham, M. A. A Complete Basis Set Model Chemistry. II. Open-Shell Systems and the Total Energies of the First-Row Atoms. J. Chem. Phys. 1991, 94, 60816090.

${ }^{30}$ Weigend, F.; Ahlrichs, R. Balanced Basis Sets of Split Valence, Triple Zeta Valence and Quadruple Zeta Valence Quality For H to Rn: Design and Assessment of Accuracy. Phys. Chem. Chem. Phys. 2005, 7, 3297-3305.

${ }^{31}$ (a) Casida, M. E.; Jamorski, C.; Casida, K. C.; Salahub, D. R. Molecular Excitation Energies to High-Lying Bound States from Time-Dependent Density-Functional Response Theory: Characterization and Correction of the Time-Dependent Local DensityApproximation Ionization Threshold. J. Chem. Phys. 1998, 108, 4439-4449. (b) Runge, E.; Gross, E. K. Density-Functional Theory for Time-Dependent Systems. Phys. Rev. Lett. 1984, 52, 997.

${ }^{32}$ Klamt, A.; Shuurmann, G. J. Chem. Soc., Perkin Trans. 2 1993, 5, 799-805. 